\title{
The Massachusetts Sustainable-Yield Estimator: A decision-support tool to assess water availability at ungaged stream locations in Massachusetts
}

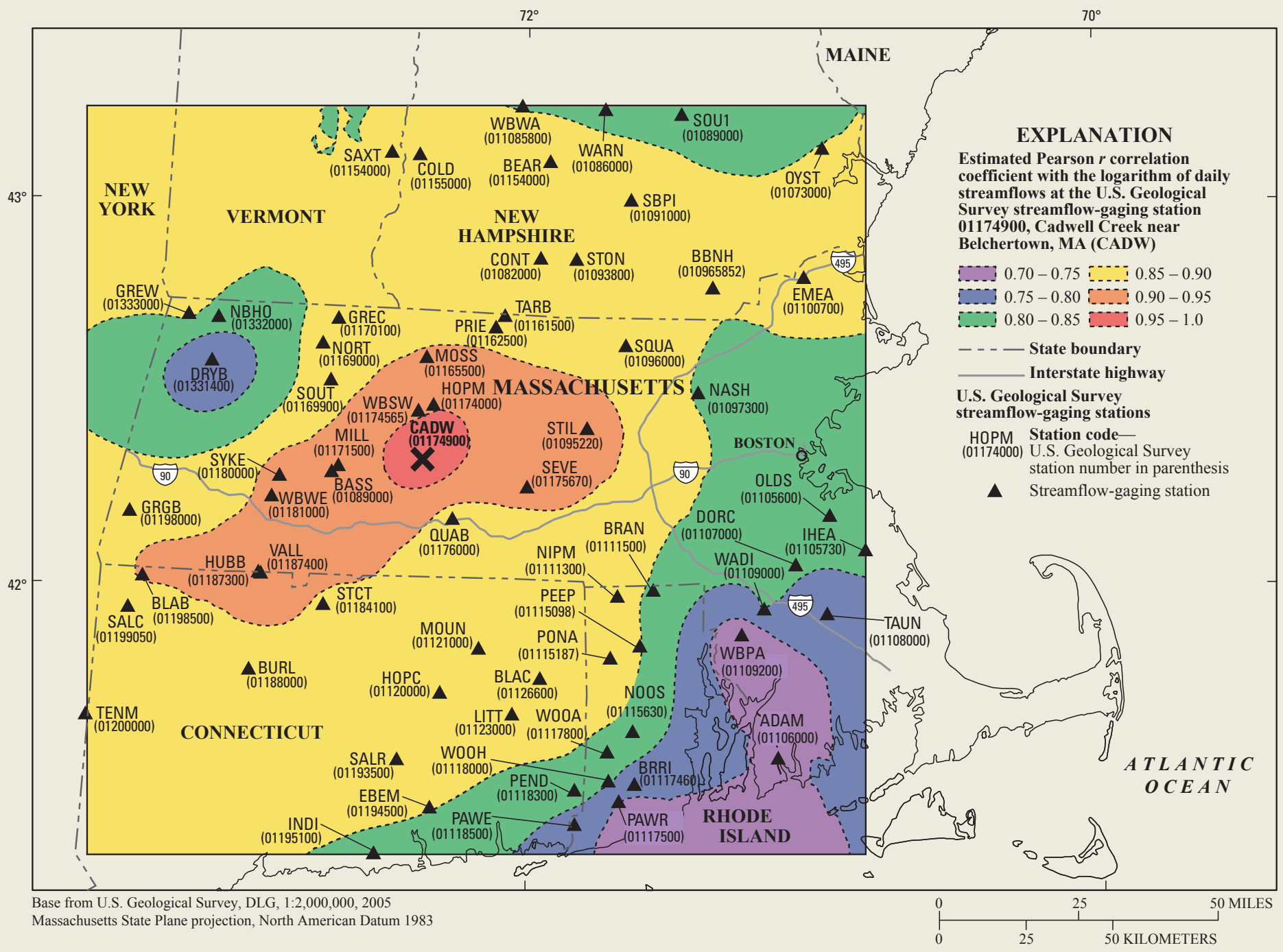

Scientific Investigations Report 2009-5227 



\section{The Massachusetts Sustainable-Yield Estimator: A decision-support tool to assess water availability at ungaged stream locations in Massachusetts}

By Stacey A. Archfield, Richard M. Vogel, Peter A. Steeves, Sara L. Brandt, Peter K. Weiskel, and Stephen P. Garabedian

Prepared in cooperation with the

Massachusetts Department of Environmental Protection

Scientific Investigations Report 2009-5227 


\title{
U.S. Department of the Interior \\ KEN SALAZAR, Secretary \\ U.S. Geological Survey \\ Marcia K. McNutt, Director
}

\section{U.S. Geological Survey, Reston, Virginia: 2010}

\author{
For more information on the USGS — the Federal source for science about the Earth, its natural and living resources, \\ natural hazards, and the environment, visit http://www.usgs.gov or call 1-888-ASK-USGS \\ For an overview of USGS information products, including maps, imagery, and publications, \\ visit http://www.usgs.gov/pubprod \\ To order this and other USGS information products, visit http://store.usgs.gov
}

Any use of trade, product, or firm names is for descriptive purposes only and does not imply endorsement by the U.S. Government.

Although this report is in the public domain, permission must be secured from the individual copyright owners to reproduce any copyrighted materials contained within this report.

Suggested citation:

Archfield, S.A., Vogel, R.M., Steeves, P.A., Brandt, S.L., Weiskel, P.K., and Garabedian, S.P., 2010, The Massachusetts Sustainable-Yield Estimator: A decision-support tool to assess water availability at ungaged stream locations in Massachusetts: U.S. Geological Survey Scientific Investigations Report 2009-5227, 41 p. plus CD-ROM. 


\section{Contents}

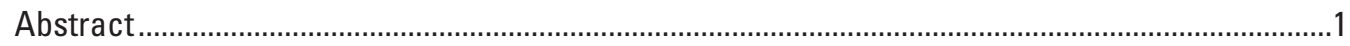

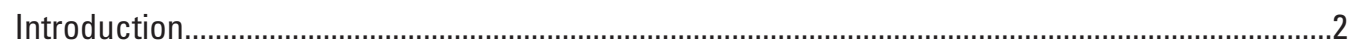

Safe versus Sustainable Yield ................................................................................................

Existing Tools to Estimate Streamflow and Assess Water Availability in Massachusetts.......2

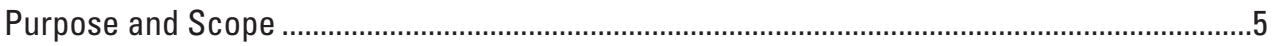

Estimation of Unregulated, Daily Mean Streamflow.......................................................................5

Estimation of a Continuous Flow-Duration Curve at Ungaged Sites .......................................5

Streamgages, Flow-Duration-Curve Statistics, and Basin Characteristics .....................5

Regression against Basin Characteristics .................................................................

Regression against Streamflow Quantiles .....................................................................

Estimation of Streamflow Time Series by use of a Reference Streamgage ............................

Reference Streamgages...................................................................................................11

Selection of a Reference Streamgage .............................................................................11

Comparison of Observed and Estimated Streamflows ..............................................................13

Uncertainty of Estimated Streamflows ......................................................................................18

Streamflow Adjusted for Groundwater and Surface-Water Withdrawals and Discharges ...........22

Reported Groundwater and Surface-Water Withdrawals and Discharges ...........................22

Disaggregation of Withdrawal and Discharge Volumes ........................................................24

Use of the STRMDEPL Program ...........................................................................................25

Estimation of Streamflow when Groundwater and Surface-Water Divides are

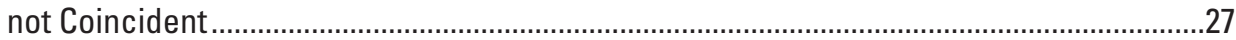

Calculation of Sustainable Yields Using the Massachusetts Sustainable-Yield Estimator

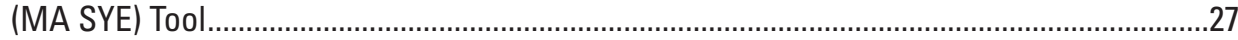

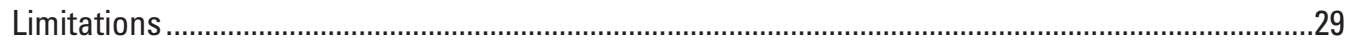

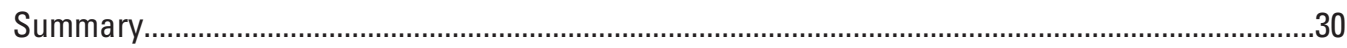

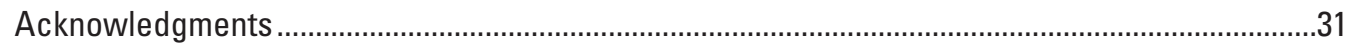

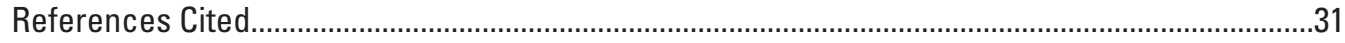

Appendix 1. Statewide maps of selected basin characteristics used to estimate unregulated, daily streamflows ...................................................................... on CD-ROM 


\section{Figures}

1. Diagram showing translation of a flow-duration curve to a time series of estimated streamflow using the QPPO method, showing (A) the observed time series, (B) flowduration curve, (C) exceedence probability, and (D) estimated time series for the Massachusetts Sustainable-Yield Estimator tool

2-4. Map showing-

2. Locations of contributing basins to 47 stream reaches monitored by U.S. Geological Survey streamgages with greater than 20 years of observed, daily mean streamflow data including streamflow during the drought of the 1960s, in Connecticut, Massachusetts, New Hampshire, New York, Vermont, and Rhode

Island, generally considered to be the southern New England study area

3. Locations of contributing basins to 66 stream reaches monitored by U.S. Geological Survey streamgages, used as reference sites to estimate unregulated, mean streamflow with the Massachusetts Sustainable-YieldEstimator tool, southern New England study area.

4. Estimated Pearson $r$ correlations with the logarithm of daily streamflows at the U.S. Geological Survey streamgages (A) 01174900, Cadwell Creek near Belchertown, MA (CADW), and (B) 01095220, Stillwater River near Sterling, MA (STIL)

5-6. Boxplots showing-

5. Distribution of basin characteristics used in six regression equations to estimate unregulated, daily mean streamflow at selected streamflow quantiles and range of characteristics used to validate the estimated mean, daily streamflows computed by the Massachusetts Sustainable-Yield Estimator (MA SYE) tool.

6. Distribution of goodness-of-fit statistics, (A) Nash-Sutcliffe efficiency values and (B) percent root-mean-square error, computed from observed and estimate mean, daily streamflow values at 18 U.S. Geological Survey streamgages.

7-9. Graphs showing-

7. Observed and estimated (A-B) annual, (C-D) monthly, and (E-F) daily mean streamflows for U.S. Geological Survey streamgages 01187300, Hubbard River near West Harland, CT (HUBB) and 01188000, Burlington Brook near Burlington, CT (BURL), southern New England study area, 1960-2004.

8. Observed and estimated streamflow quantiles by exceedence probability for U.S. Geological Survey streamgages (A, C, and D) 01187300, Hubbard River near West Harland, CT (HUBB) and (B) 01188000, Burlington Brook near Burlington, CT (BURL), southern New England study area

9. Observed and estimated streamflows for U.S. Geological Survey streamgages (A-B) 01187300, Hubbard River near West Harland, CT (HUBB) and (C-D) 01188000, Burlington Brook near Burlington, CT (BURL) showing the best $(A-B)$ and worst (C-D) agreement between unregulated observed and estimated mean, daily streamflow, in linear space and log space, southern New England study area, 1960-62.

10. Boxplots showing distribution of observed streamflow and streamflow estimated by the Massachusetts StreamStats and Massachusetts Sustainable-Yield-Estimator tool for eight exceedence probabilities at 29 U.S. Geological Survey streamgages in Massachusetts. 
11. Graph showing Nash-Sutcliffe efficiency values obtained from the cross-validation experiments in relation to values obtained from regression equations to estimate uncertainty in the daily unregulated streamflows estimated by the Massachusetts Sustainable-Yield-Estimator tool

12. Map showng locations of groundwater and surface-water withdrawals and discharges in Massachusetts used by the Massachusetts Sustainable-YieldEstimator tool to adjust the unregulated, daily mean streamflow...

13. Boxplots showing distribution of the monthly fraction of the total annual withdrawal volumes for (A) groundwater and (B) surface-water public-water-supply withdrawals in Massachusetts.

14. Graph showing streamflow depletion estimated by the STRMDEPL program for a range of diffusivity values and distances between a hypothetical withdrawal location and stream.

15. Map showing locations in Massachusetts near the mouths of major streams for which unregulated and regulated streamflows were simulated using a groundwater-flow model because groundwater and surface-water divides are not coincident

\section{Tables}

1. Summary of 66 U.S. Geological Survey streamgages, number of streamflow observations, and the periods of observed, daily mean streamflow record, New England study area

2. Streamflow quantiles corresponding to 17 exceedence probabilities estimated from the observed period of record at 47 U.S. Geological Survey streamgages, New England study area

3. Basin, climate, and land-use characteristics at five U.S. Geological Survey streamgages, tested for use in the Massachusetts Sustainable-Yield Estimator tool .....8

4. Number of streamgages, regression method, explanatory variables, estimated regression coefficients, and regression diagnostics for streamflows at six exceedence probabilities used to estimate the daily, period-of-record flow-duration curve with the Massachusetts Sustainable-Yield-Estimator tool

5. Number of streamgages, regression method, explanatory variables, estimated regression parameters, and regression diagnostics for streamflows at 11 exceedence probabilities used to estimate the daily period-of-record flow-duration curve for the Massachusetts Sustainable-Yield-Estimator tool.

6. Description of MOVE.3 (Vogel and Stedinger, 1985) record extension for four U.S. Geological Survey reference streamgages in the New England study area

7. Water-use type, number of sites, reporting units and statistics, and time and spatial resolution of water withdrawal and discharge sites in the statewide water-use database used with the Massachusetts Sustainable-Yield-Estimator tool to adjust daily, unregulated streamflow at ungaged sites in Massachusetts....

8. Source of water withdrawals, towns, and years of monthly data used to determine characteristic demand curves for public water supply groundwater and surfacewater withdrawals in Massachusetts. 


\section{Conversion Factors}

\begin{tabular}{|c|c|c|}
\hline Multiply & By & To obtain \\
\hline \multicolumn{3}{|c|}{ Length } \\
\hline foot $(\mathrm{ft})$ & 0.3048 & meter $(\mathrm{m})$ \\
\hline mile (mi) & 1.609 & kilometer $(\mathrm{km})$ \\
\hline yard (yd) & 0.9144 & meter $(\mathrm{m})$ \\
\hline \multicolumn{3}{|c|}{ Area } \\
\hline square foot $\left(\mathrm{ft}^{2}\right)$ & 0.09290 & square meter $\left(\mathrm{m}^{2}\right)$ \\
\hline square mile $\left(\mathrm{mi}^{2}\right)$ & 2.590 & square kilometer $\left(\mathrm{km}^{2}\right)$ \\
\hline \multicolumn{3}{|c|}{ Volume } \\
\hline gallon (gal) & 0.003785 & cubic meter $\left(\mathrm{m}^{3}\right)$ \\
\hline million gallons (Mgal) & 3,785 & cubic meter $\left(\mathrm{m}^{3}\right)$ \\
\hline cubic foot $\left(\mathrm{ft}^{3}\right)$ & 0.02832 & cubic meter $\left(\mathrm{m}^{3}\right)$ \\
\hline \multicolumn{3}{|c|}{ Flow rate } \\
\hline cubic foot per second $\left(\mathrm{ft}^{3} / \mathrm{s}\right)$ & 0.02832 & cubic meter per second $\left(\mathrm{m}^{3} / \mathrm{s}\right)$ \\
\hline $\begin{array}{l}\text { cubic foot per second per square } \\
\text { mile }\left[\left(\mathrm{ft}^{3} / \mathrm{s}\right) / \mathrm{mi}^{2}\right]\end{array}$ & 0.01093 & $\begin{array}{l}\text { cubic meter per second per square } \\
\text { kilometer }\left[\left(\mathrm{m}^{3} / \mathrm{s}\right) / \mathrm{km}^{2}\right]\end{array}$ \\
\hline cubic foot per day $\left(\mathrm{ft}^{3} / \mathrm{d}\right)$ & 0.02832 & cubic meter per day $\left(\mathrm{m}^{3} / \mathrm{d}\right)$ \\
\hline gallon per day (gal/d) & 0.003785 & cubic meter per day $\left(\mathrm{m}^{3} / \mathrm{d}\right)$ \\
\hline million gallons per day (Mgal/d) & 0.04381 & cubic meter per second $\left(\mathrm{m}^{3} / \mathrm{s}\right)$ \\
\hline \multicolumn{3}{|c|}{ Specific capacity } \\
\hline $\begin{array}{l}\text { gallon per minute per foot } \\
[(\mathrm{gal} / \mathrm{min}) / \mathrm{ft})]\end{array}$ & 0.2070 & liter per second per meter $[(\mathrm{L} / \mathrm{s}) / \mathrm{m}]$ \\
\hline \multicolumn{3}{|c|}{ Hydraulic conductivity } \\
\hline foot per day (ft/d) & 0.3048 & meter per day $(\mathrm{m} / \mathrm{d})$ \\
\hline \multicolumn{3}{|c|}{ Transmissivity* } \\
\hline foot squared per day $\left(\mathrm{ft}^{2} / \mathrm{d}\right)$ & 0.09290 & meter squared per day $\left(\mathrm{m}^{2} / \mathrm{d}\right)$ \\
\hline
\end{tabular}

Temperature in degrees Celsius $\left({ }^{\circ} \mathrm{C}\right)$ may be converted to degrees Fahrenheit $\left({ }^{\circ} \mathrm{F}\right)$ as follows:

${ }^{\circ} \mathrm{F}=\left(1.8 \times^{\circ} \mathrm{C}\right)+32$

Temperature in degrees Fahrenheit $\left({ }^{\circ} \mathrm{F}\right)$ may be converted to degrees Celsius $\left({ }^{\circ} \mathrm{C}\right)$ as follows:

${ }^{\circ} \mathrm{C}=\left({ }^{\circ} \mathrm{F}-32\right) / 1.8$

Horizontal coordinate information is referenced to the North American Datum of 1983 (NAD 83).

*Transmissivity: The standard unit for transmissivity is cubic foot per day per square foot times foot of aquifer thickness [(ft $\left.\left.\mathrm{ft}^{3} / \mathrm{d}\right) / \mathrm{ft}^{2}\right] \mathrm{ft}$. In this report, the mathematically reduced form, foot squared per day $\left(\mathrm{ft}^{2} / \mathrm{d}\right)$, is used for convenience. 


\section{Abbreviations}

$\begin{array}{ll}\text { EPA } & \text { Environmental Protection Agency } \\ \text { ESRI } & \text { Environmental Systems Research Institute, Inc. } \\ \text { MassDEP } & \text { Massachusetts Department of Environmental Protection } \\ \text { MassGIS } & \text { Massachusetts Geographic Information System } \\ \text { MA SYE } & \text { Massachusetts Sustainable-Yield Estimator } \\ \text { NPDES } & \text { National Pollutant Discharge Elimination System } \\ \text { FDC } & \text { Flow-duration curve } \\ \text { GIS } & \text { Geographic-information system } \\ \text { IHA } & \text { Indicators of Hydrologic Alteration } \\ \text { NAHAT } & \text { National Hydrologic Assessment Tool } \\ \text { N-S E } & \text { Nash-Sutcliffe efficiency } \\ \text { NPDES } & \text { National Pollutant Discharge Elimination System } \\ \text { PDF } & \text { Probability density function } \\ \text { STRMDEPL } & \text { STReaMflow DEPLetion by wells } \\ \text { WMA } & \text { Water Management Act }\end{array}$


(This page intentionally left blank) 


\title{
The Massachusetts Sustainable-Yield Estimator: A decision-support tool to assess water availability at ungaged stream locations in Massachusetts
}

\author{
By Stacey A. Archfield, Richard M. Vogel, Peter A. Steeves, Sara L. Brandt, Peter W. Weiskel, \\ and Stephen P. Garabedian
}

\section{Abstract}

Federal, State and local water-resource managers require a variety of data and modeling tools to better understand water resources. The U.S. Geological Survey, in cooperation with the Massachusetts Department of Environmental Protection, has developed a statewide, interactive decision-support tool to meet this need. The decision-support tool, referred to as the Massachusetts Sustainable-Yield Estimator (MA SYE) provides screening-level estimates of the sustainable yield of a basin, defined as the difference between the unregulated streamflow and some user-specified quantity of water that must remain in the stream to support such functions as recreational activities or aquatic habitat. The MA SYE tool was designed, in part, because the quantity of surface water available in a basin is a time-varying quantity subject to competing demands for water.

To compute sustainable yield, the MA SYE tool estimates a daily time series of unregulated, daily mean streamflow for a 44-year period of record spanning October 1, 1960, through September 30, 2004. Selected streamflow quantiles from an unregulated, daily flow-duration curve are estimated by solving six regression equations that are a function of physical and climate basin characteristics at an ungaged site on a stream of interest. Streamflow is then interpolated between the estimated quantiles to obtain a continuous daily flow-duration curve. A time series of unregulated daily streamflow subsequently is created by transferring the timing of the daily streamflow at a reference streamgage to the ungaged site by equating exceedence probabilities of contemporaneous flow at the two locations. One of 66 reference streamgages is selected by kriging, a geostatistical method, which is used to map the spatial relation among correlations between the time series of the logarithm of daily streamflows at each reference streamgage and the ungaged site. Estimated unregulated, daily mean streamflows show good agreement with observed unregulated, daily mean streamflow at 18 streamgages located across southern New England. Nash-Sutcliffe efficiency goodness-of-fit values are between 0.69 and 0.98 , and percent root-mean-square-error values are between 19 and 283 percent.

The MA SYE tool provides an estimate of streamflow adjusted for current (2000-04) water withdrawals and discharges using a spatially referenced database of permitted groundwater and surface-water withdrawal and discharge volumes. For a user-selected basin, the database is queried to obtain the locations of water withdrawal or discharge volumes within the basin. Groundwater and surface-water withdrawals and discharges are subtracted and added, respectively, from the unregulated, daily streamflow at an ungaged site to obtain a streamflow time series that includes the effects of these withdrawals and discharges. Users also have the option of applying an analytical solution to the time-varying, groundwater withdrawal and discharge volumes that take into account the effects of the aquifer properties on the timing and magnitude of streamflow alteration.

For the MA SYE tool, it is assumed that groundwater and surface-water divides are coincident. For areas of southeastern Massachusetts and Cape Cod where this assumption is known to be violated, groundwater-flow models are used to estimate average monthly streamflows at fixed locations. The MA SYE tool can be applied only to basins with ranges of physical and climate basin characteristics that are within the range under which the regression equations were developed. For example, the MA SYE tool is valid for basins whose drainage areas are between approximately 4 and 294 square miles. There are several limitations to the quality and quantity of the spatially referenced database of groundwater and surface-water withdrawals and discharges. The adjusted streamflow values do not account for the effects on streamflow of climate change, septic-system discharge, impervious area, non-public watersupply withdrawals less than 100,000 gallons per day, and impounded surface-water bodies. 


\section{Introduction}

The amount of surface water available for withdrawal in a basin is dependent upon several variables including, but not limited to, the total amount of water available (the unregulated streamflow at the outlet of the basin), the amount of water being withdrawn or discharged at a moment in time from the basin, the effects of those withdrawals or discharges on streamflow, the period of analysis, and the amount of water that may be needed to sustain aquatic habitat or support recreational uses. Surface-water availability also is dependent upon the effects of land cover (urbanization) and dams (both passive and actively managed dams) on streamflow, and the effects of climate change.

\section{Safe versus Sustainable Yield}

The term "safe yield" has historically been used to describe the amount of water available from a groundwater or surface-water source. Typically, the concept of safe yield implies that a single value represents the water available for withdrawal in a basin given some singular constraint, such as an engineering limitation or climate condition. In Massachusetts, legislation requires the Massachusetts Department of Environmental Protection (MassDEP) to regulate the permitting of water withdrawals greater than a 100,000 gallon-per-day threshold volume relative to the safe yield of a basin (Massachusetts Water Management Act, M.G.L. c. 21G). The exact regulatory definition of safe yield (from $310 \mathrm{CMR}$ 36.00: The Water Management Act Regulations) is

...the maximum dependable withdrawals that can be made continuously from a water source, including ground or surface water, during a period of years in which the probable driest period or period of greatest water deficiency is likely to occur; provided however, that such dependability is relative and is a function of storage and drought probability.

This definition is consistent with the historical interpretation of safe yield as a single value determined from a sole constraint on water availability; in the Massachusetts definition, that constraint is a period of severe drought. In recent years, attention has been given to other constraints that may affect the water availability in a basin, such as the preservation of the aquatic resources of the basin. Historically, this constraint has been a minimum-flow target that is constant over time. Poff and others (1997) state that the ecological-flow needs of a basin should reproduce the "natural-flow regime," meaning that ecological-flow needs should reflect the magnitude, frequency, duration, timing, and rate of change that occurs naturally in streamflow. A single minimum-flow target would not be adequate to meet those needs; therefore, the sustainable yield of the basin, if constrained by ecological-flow needs, will not be a constant value.
To address the limitations of the safe-yield definition, recent literature has proposed that water availability is better expressed as a "sustainable yield" rather than a safe yield (Sophocleous, 2000; Alley and Leake, 2004; and Maimone, 2004). Sustainable yield is a measure of water availability that simultaneously considers the spatial and temporal availability of water (Maimone, 2004), as well as the complex interplay between the time varying and competing demands for water, such as human and ecological water needs (Alley and Leake, 2004). The concept of sustainable yield signifies the complexity and interdependence of some variables that affect water availability. To understand and quantify the sustainable yield of a basin, water managers and planners require flexible tools that address as many of these variables as possible and at the appropriate time scales.

\section{Existing Tools to Estimate Streamflow and Assess Water Availability in Massachusetts}

The calculation of sustainable yield and water availability in a basin require an estimate of unregulated, or baseline, streamflow conditions at the time scales appropriate to understanding the competing needs for water in a basin. For example, assessment tools used to understand ecological-flow needs typically require baseline streamflow values at the daily time scale (Black and others, 2005; The Nature Conservancy, 2005; Hendrickson and others, 2006). A variety of modeling tools have been used to estimate water availability in ungaged basins in Massachusetts; however, not all tools provide data on streamflow at the daily scale. These tools range from regression models that estimate annual or low-flow conditions at regional scales using a small set of explanatory characteristics of an ungaged basin (for example, Vogel and others, 1999 and Reis and Friesz, 2000) to calibrated, physically based models tailored to the conditions of individual Massachusetts Planning Basins (DeSimone and others, 2002; DeSimone, 2004; Zarriello and Ries, 2000; Barbaro and Zarriello, 2006; Barbaro, 2007).

In Massachusetts, quantile-based regression models were used to estimate selected unregulated low-flow streamflow statistics by relating the physical and climate characteristics of gaged basins to 13 low-flow streamflow statistics (Reis and Friesz, 2000). Reis and Friez (2000) related the median August streamflow value; the 7-day, 2-year and the 7-day, 10-year streamflow values; and streamflow quantiles at the 50-, 60-, 70-, 75-, 80-, 85-, 90-, 95-, 98-, and 99-percent exceedence probabilities (that is, the streamflow values exceeded 50, 60, $70,75,80,85,90,95,98$, and 99 percent of the time, respectively) to the drainage area, mean basin slope, area of terrain underlain by stratified drift per unit of total stream length, and the location of the basin. These quantile-based regression equations are currently used in the Massachusetts StreamStats application (U.S. Geological Survey, 2009) to estimate unregulated low-flow streamflow statistics at ungaged sites. 
Fennessey (1994) and Fennessey and Vogel (1990) used a parameter-based regression model to estimate daily streamflow quantiles at ungaged locations in the northeastern and mid-Atlantic United States, including Massachusetts. The parameter-based regression model, in which it is assumed that daily streamflow values can be represented by a particular continuous probability density function (PDF), provides a simple equation for approximating the structure of daily streamflow. The parameters of the PDF are regressed against readily measured physical and climate characteristics of gaged basins to estimate daily streamflow quantiles at an ungaged site. Fennessey (1994) found that the parameters of the generalized Pareto distribution were related to the drainage area, average annual precipitation, average annual snowfall, runoffcurve number (Soil Conservation Service, 1986), mean channel slope, and mean elevation of the basin (Fennessey, 1994). Whereas the Reis and Friesz (2000) regression equations estimate streamflow quantiles only at the 50-, 60-, 70-, 75-, 80-, 85-, 90-, 95-, 98-, and 99-percent exceedence probabilities, the parameter-based regression model can provide an estimate of a streamflow quantile at any exceedence probability, including the high-flow quantiles, which were not estimated by Ries and Friesz (2000).

In contrast to statistically based regression models that require only a few parameters to estimate streamflow, physically based basin models can be used to estimate streamflows at the monthly, daily, or sub-daily time scales. Basin models simulate specific hydrologic processes such as runoff generation, evapotranspiration, groundwater and surface-water interactions, and hydrologic responses to pumping and discharge stresses. In some cases, model uncertainty is explicitly considered (Walter and Leblanc, 2008). Such models are appropriate for detailed evaluation of the hydrologic effects of human stresses on streamflows, lake levels, and groundwater levels. Nonetheless, due to the substantial training, expertise, and time required to calibrate and use these physically based models, implementation of these models for a statewide, screening-level assessment of water availability is both cost and time prohibitive.

Mid-range in complexity between regression-based models and physically based models is the QPPQ method, introduced and named by Fennessey (1994) and also published by Hughes and Smakhtin (1996), Smakhtin (1999), Smakhtin and Masse (2000), and Mohamoud (2008). Fennessey (1994) paired the parameter-regression model with the use of a reference streamgage to estimate an unregulated, daily mean streamflow time series at an ungaged site. In this approach, daily streamflow quantiles at the ungaged site are estimated using the parameter-based regression model, which results in a continuous daily flow-duration curve (FDC) (the relation between exceedence probability and streamflow for each day of observed streamflow) at the ungaged site. The FDC is translated into a time series by use of a reference streamgage. As explained in Waldron and Archfield (2006), the observed time series of streamflow at the reference streamgage (Q) (fig. 1A) is used to construct an FDC (fig. 1B), which represents the probability of exceedence $(\mathrm{P})$ for each unique streamflow value in the record. The assumption is then made that the probability of exceeding a flow at the reference streamgage is equivalent to the probability of exceeding a flow at the ungaged site (P) (fig. 1C). Lastly, by equating the exceedence probabilities at the ungaged site and reference streamgage, the dates of streamflow associated with each exceedence probability at the reference streamgage are transferred to the ungaged site to assemble a time series of streamflow at the ungaged site (Q) (fig. 1D).

The parameter-regression method coupled with the QPPQ method developed by Fennessey (1994) has been previously applied in the estimation of inflows to drinking-water reservoirs in Massachusetts (Waldron and Archfield, 2006). However, the parameter-regression equations in Fennessey (1994) cannot be used to estimate the FDC in an interactive, GISbased application because the calculation of the runoff-curve number is not able to be automated. Archfield (2009) demonstrated several issues with the assumption that the generalized Pareto PDF can represent the structure of daily streamflow. Also, the selection criteria for the reference streamgage were not addressed in Fennessey (1994) or Waldron and Archfield (2006).

To provide estimates of the unregulated, daily mean streamflow and, ultimately, a tool to estimate screening-level values of sustainable yield for a basin in Massachusetts, the U.S. Geological Survey, in cooperation with the Massachusetts Department of Environmental Protection, has developed a statewide, interactive decision-support tool termed the Massachusetts Sustainable-Yield-Estimator (MA SYE) tool. In addition to estimating screening-level values of sustainable yield for a basin, users of the MA SYE can compare the sustainable yield values to estimates of daily streamflow adjusted for current (2000-04) permitted water withdrawals and discharges in the basin of interest.

The MA SYE tool is a hindcasting tool that estimates unregulated, daily mean streamflow over a 44-year period from October 1, 1960, through September 30, 2004. Unregulated, daily mean streamflows are estimated using a quantilebased regression method similar to the equations in Ries and Friesz (2000) coupled with the QPPQ method (Fennessey, 1994; Hughes and Smakhtin, 1996; Smakhtin, 1999; Smakhtin and Masse, 2000; Mohamoud, 2008).

Supporting technical details on the development of the methods used by the MA SYE tool are provided in Archfield (2009). For the tool to compute sustainable yield, users provide flow targets specifying the quantity of water to remain in the stream to meet ecological flow, recreational flow, or some other need. Water withdrawals and discharges are used in the MA SYE tool to adjust unregulated daily mean streamflow. In this study, flows at streamgages in southern New England were related to readily available physical and climate basin characteristics to develop quantile-based regression models, and a criterion was developed to select the reference streamgage. 


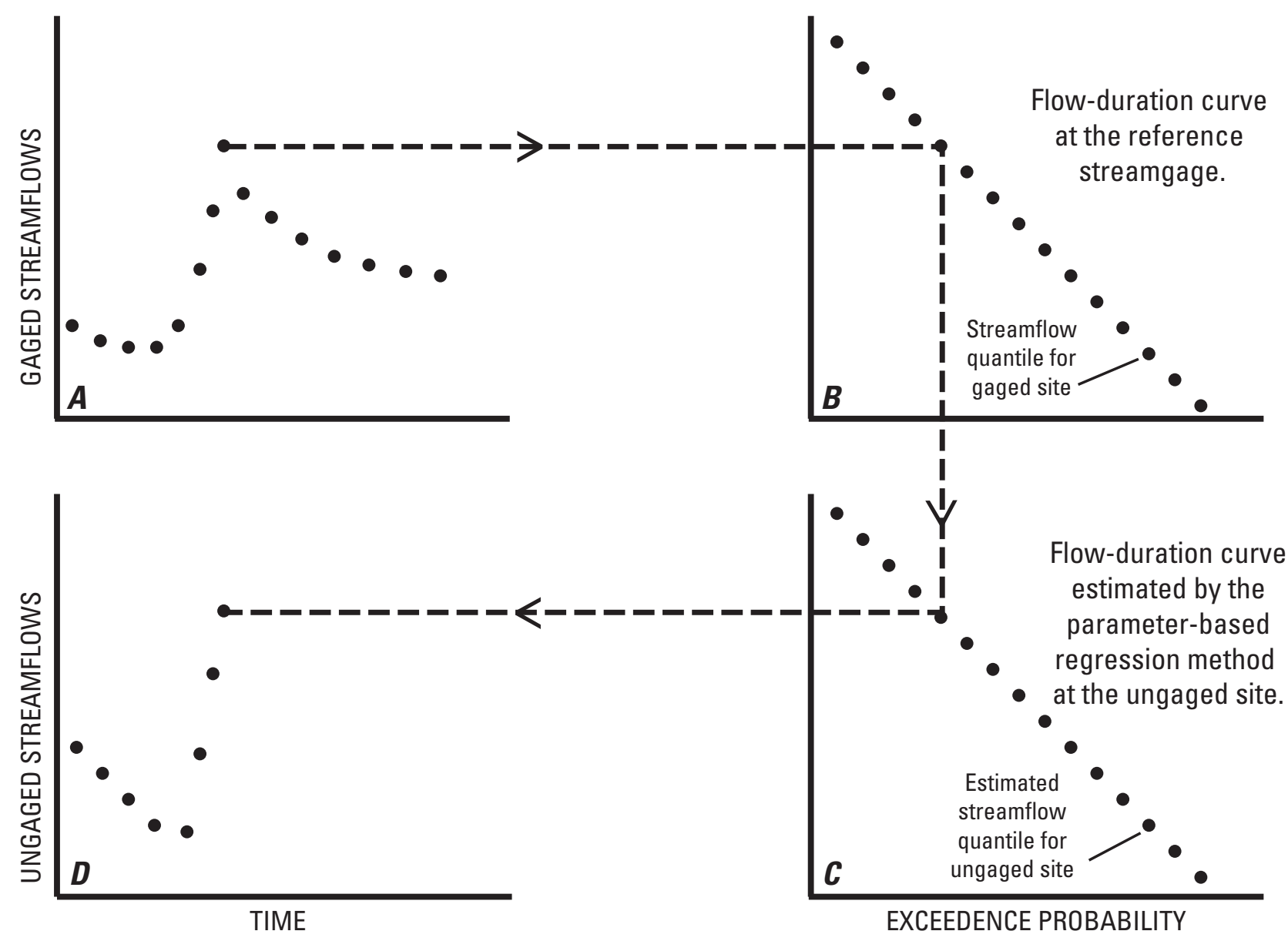

Figure 1. Translation of a flow-duration curve to a time series of estimated streamflow using the QPPQ method, showing (A) the observed time series, (B) flow-duration curve, (C) exceedence probability, and (D) estimated time series for the Massachusetts Sustainable-Yield Estimator tool. (Adapted from Fennessey, 1994, and Waldron and Archfield, 2006). 


\section{Purpose and Scope}

This report represents the release and documentation of the MA SYE tool, which is used to determine streamflow at ungaged sites in Massachusetts. The data and methods used to develop the tool are documented, as well as the functionality and limitations.

\section{Estimation of Unregulated, Daily Mean Streamflow}

Unregulated, daily mean streamflow values are estimated for a period of 16,071 days (44 years from October 1, 1960, through September 30, 2004) using the MA SYE tool. Unregulated, daily mean streamflow values are used in the MA SYE tool to provide the baseline streamflow conditions from which user-specified flow targets are subtracted to determine sustainable-yield values for the basin. The MA SYE tool is used to estimate unregulated, daily streamflow with a twostep process that expands on the works of Fennessey (1994), Hughes and Smakhtin (1996), Smakhtin (1999), Smakhtin and Masse (2000), Ries and Friesz (2000), and Mohamoud (2008). First, the MA SYE tool is used to estimate a continuous daily FDC, which is based on 16,071 streamflow quantiles (one value for each day in the study period). The estimated streamflows are then transformed to a time series of daily streamflow using the QPPQ method (fig. 1) (Fennessey, 1994; Hughes and Smakhtin, 1996; Smakhtin, 1999; Smakhtin and Masse, 2000; Mohamoud, 2008).

\section{Estimation of a Continuous Flow-Duration Curve at Ungaged Sites}

Quantile-based regression is used to estimate streamflow quantiles for six exceedence probabilities. An additional 11 streamflow quantiles are estimated by solving a regression equation that uses another estimated streamflow quantile as the explanatory variable. The remaining 16,054 streamflow quantiles are determined by log-linear interpolation to obtain a continuous daily FDC with 16,071 streamflow quantiles.

Although Reis and Friesz (2000) also used quantile-based regression equations, new quantile-based regression equations were developed because of the availability of recent highresolution data sets, as well as additional streamflow data, all published since 2000. Furthermore, Reis and Friesz (2000) developed regression equations only for low-flow streamflow quantiles. The parameter-based regression equations used by Fennessey (1994) were not considered for use in estimating the FDC because of the challenges in determining an appropriate PDF to represent daily streamflow (Archfield, 2009).

\section{Streamgages, Flow-Duration-Curve Statistics, and Basin Characteristics}

Armstrong and others (2008) identified 85 USGS streamgages that monitor the least-regulated streams/stream reaches in southern New England. A subset of 47 streamgages and contributing basins were used to estimate the FDC at an ungaged site (fig. 2). The 47 streamgages were selected because the observed streamflow record contained greater than 20 years of values, including records from the drought of the 1960s (table 1, at end of report). This drought encompassed Massachusetts and is generally considered the drought of record. Armstrong and others (2008) provide a detailed description of the geologic, hydrologic, and climatic conditions in the study area, as well as information on water use, land cover, and the presence of dams within the study basins. Daily, continuous streamflow observations at the 47 streamgages were recorded for 20 to 86 years. Additional information on the locations, streamgage names and numbers, and periods of record can be found in Armstrong and others (2008).

To develop the quantile-based regression equations, the dependent variable, the streamflow quantiles, and the independent variables, which are the physical and climate basin characteristics, were quantified for each of the 47 streamgages. To compute the streamflow quantiles, the observed daily streamflows were ranked and an exceedence probability was computed for each corresponding ranked streamflow using the Weibull plotting position (Stedinger and others, 1993). Streamflow quantiles were estimated at the following: the $0.01,0.05,0.10,0.15,0.20,0.30,0.40,0.50,0.60,0.70,0.80$, $0.85,0.9,0.95$, and 0.99 exceedence probabilities (table 2 , at end of report). The 15 streamflow quantiles include 8 quantiles also estimated by Ries and Friesz (2000) and 7 quantiles that represent high flows, which correspond to streamflows at low exceedence probabilities. Streamflow quantiles at the 0.00062 and 0.999938 exceedence probabilities also were estimated from the observed streamflow data (table 2, at end of report). The 0.00062 and 0.999938 exceedence probabilities are those for the largest and smallest streamflow quantiles calculated using the Weibull plotting position for a record containing 16,071 streamflow observations. The streamflow values are estimated with the MA SYE tool to provide upper and lower bounds on the estimated daily streamflows. The streamflows at the 0.00062 and 0.999938 exceedence probabilities were estimated for only 26 streamgages because a streamflow record of at least 16,071 daily observations is required to estimate these quantiles. Streamflow quantiles at each of the 17 exceedence probabilities were estimated from their observed streamflow records using the non-parametric quantile estimators presented in equations 2a and 2b of Vogel and Fennessey (1994). 


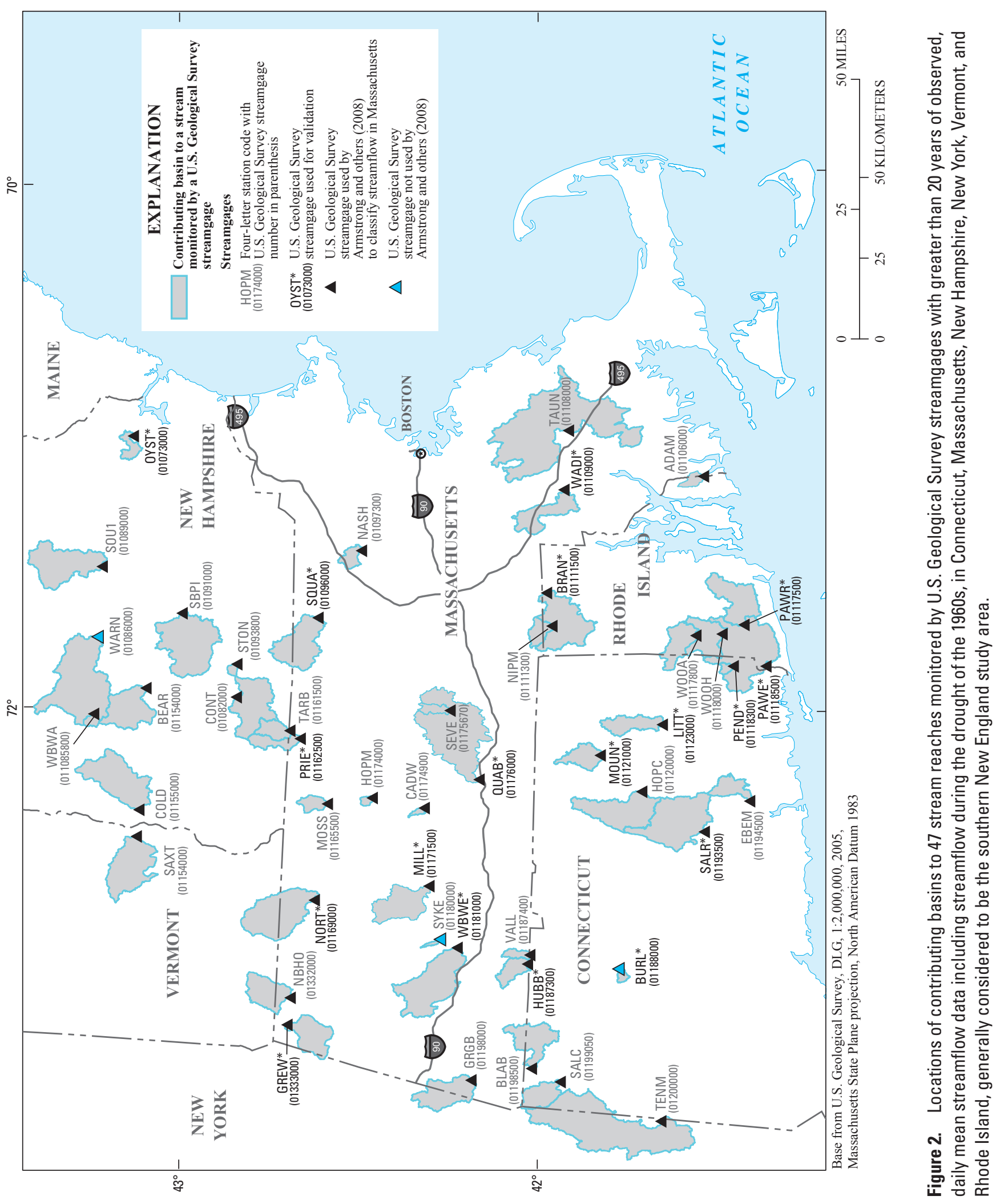


This study tested 22 physical and climate basin characteristics (table 3) for use as explanatory (independent) variables. Armstrong and others (2008) provide the basin characteristics for 44 of the 47 streamgages, as well as details about the source and resolution of the characteristics. Physical and climate basin characteristics for the three streamgages not reported in Armstrong and others (2008) are given in table 3. Location variables also were tested as explanatory variables because they are considered substitutes for spatially varying characteristics that could not be readily obtained.

\section{Regression against Basin Characteristics}

Streamflow values at the $0.000062,0.01,0.05,0.2,0.4$, and 0.8 exceedence probabilities (table 2 ) were regressed against the 22 basin characteristics listed in table 3 . Regression equations were developed using weighted least-squares and ordinary least-squares regression (table 4). When weighted least-squares regression was used, regression weights were applied to the dependent variables and were computed as a function of the number of days of observed streamflow on which the estimated streamflow statistic was based. Two sets of regression equations were initially developed; one set of equations resulted from the use of the ordinary least-squares method and one set of equations resulted from the use of the weighted least-squares regression method. The final regression equations developed for streamflow quantiles at the $0.2,0.4$, and 0.8 exceedence probabilities used the ordinary leastsquares regression equations because substantial reduction in prediction errors were observed over the weighted leastsquares regression equations at these streamflow quantiles. Furthermore, streamflow quantiles used as the dependent variables in the regression equations were estimated using at least 20 years (7,300 days) of daily observations, making it unlikely that the record length affected the estimates of these quantiles.

Natural-log transformations of the dependent variables (streamflow quantiles at selected exceedence probabilities) and explanatory variables (physical and climate basin characteristics) were conducted to effectively linearize the relations between the variables. Because the regression equations were developed in logarithmic space, the form of the regression equation is

$$
\mathrm{Y}=\exp ^{\beta 0} \mathrm{X}_{1}^{\beta 1} \mathrm{X}_{2}^{\beta 2} \ldots \mathrm{X}_{\mathrm{n}}^{\beta \mathrm{n}} \exp ^{\mathrm{BCF}}
$$

where

$$
\begin{gathered}
\mathrm{Y} \text { is the dependent variable (the streamflow } \\
\text { quantiles), } \\
\mathrm{X}_{\mathrm{n}} \quad \begin{array}{l}
\text { is the independent variables (either a basin } \\
\text { characteristic or another estimated } \\
\text { streamflow quantile), }
\end{array}
\end{gathered}
$$

$$
\begin{aligned}
& \beta_{\mathrm{n}} \quad \text { is the regression estimated coefficient for } \\
& \text { explanatory variable } \mathrm{X}_{\mathrm{n}} \text {, } \\
& \beta_{0} \quad \text { is the regression-estimated constant term, } \\
& \text { exp is the base of the natural logarithm and, } \\
& \mathrm{BCF} \text { is the bias correlation factor. }
\end{aligned}
$$

Bias correction factors were estimated using the Smearing Estimator (Duan, 1983) to remove bias in the regression estimates of the streamflow quantiles. Zero values in the regression variables were present in less than 2 percent of the basin characteristics. A streamgage with a zero value for a particular characteristic was not used to test the significance of that basin characteristic. Streamflow quantile values were all greater than zero.

The statistical software package Minitab was used to develop the regression equations. Stepwise regression was used to narrow the 22 basin characteristics to a smaller pool of potentially significant basin characteristics. All regression coefficients in the regression equations were significantly different from zero at the 0.05 significance level (table 4). Residuals (observed minus regression-estimated streamflow values) (plotted in log space) were generally homoscedastic and effectively normally distributed with greater than 75-percent confidence. Sites that greatly affected the fit of the regression models were removed from the final equations. These were sites such that their inclusion substantially reduced model fit. Variables in the final equations had variance-inflation factors of less than 2.5, meaning the correlations between the independent variables are minimal. Regression-coefficient values and other diagnostics are shown in table 4.

Daily streamflows are complex, and physical and climate processes affect portions of the FDC differently; different variables are related to different streamflow quantiles. For example, the percent of terrain underlain by sand and gravel deposits can affect low streamflow values; however, high streamflow values are not related to this variable (table 4). Percent of basin that is open water is used to estimate streamflow for the 40-percent exceedence probability and is negatively correlated with streamflow (table 4). Percent of basin that is wetlands is used to estimate streamflow for the 1-percent exceedence probability and is negatively correlated with streamflow (table 4). Average annual precipitation is used to estimate streamflow for the 1-, 5-, 20-, and 40-percent exceedence probabilities and is positively correlated with streamflow (table 4). Average maximum monthly temperature is used to estimate streamflow for the 80-percent exceedence probability and is negatively correlated with streamflow (table 4). Percent of basin of underlain by sand and gravel deposits was found to have a significant effect on the regression equation used to estimate streamflow at the 40 - and 80 -percent exceedence probabilities and is positively correlated with streamflow (table 4). Statewide maps of these characteristics are presented in appendix 1. 
Table 3. Basin, climate, and land-use characteristics at five U.S. Geological Survey streamgages, tested for use in the Massachusetts Sustainable-Yield Estimator tool.

[These streamgages are not listed in table 3 of Armstrong and others (2008). Sources of the characteristics can be found in Armstrong and others (2008). Elevation characteristics are determined from the U.S. Geological Survey 30-meter National Elevation Dataset.]

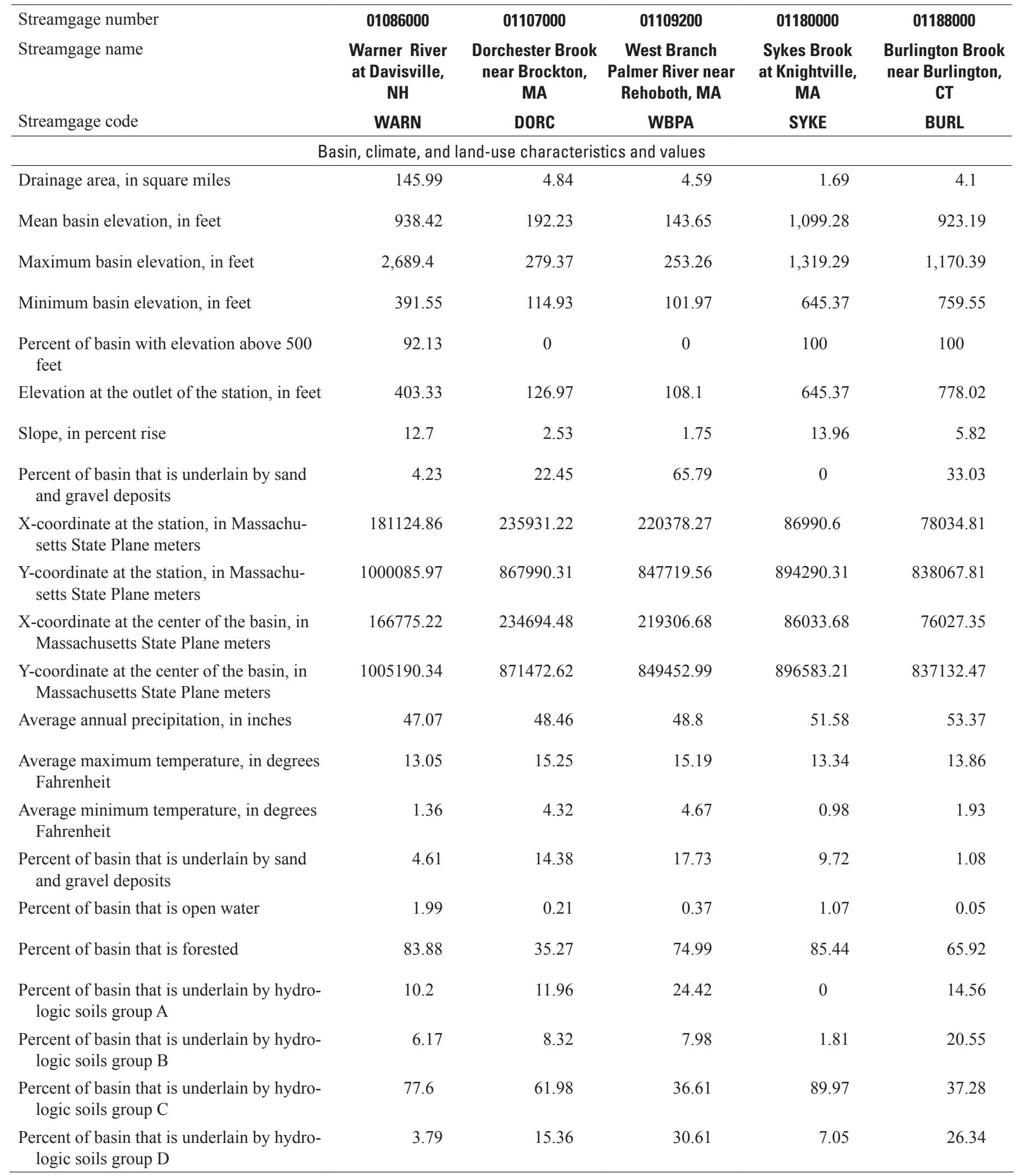


Table 4. Number of streamgages, regression method, explanatory variables, estimated regression coefficients, and regression diagnostics for streamflows at six exceedence probabilities used to estimate the daily, period-of-record flow-duration curve with the Massachusetts Sustainable-Yield-Estimator tool.

$[* *$, characteristic not included in regression equation; $\dagger$, Bias correction factor computed from Duan (1983), WLS, weighted-least squares; OLS, ordinaryleast squares]

\begin{tabular}{|c|c|c|c|c|c|c|}
\hline Exceedance probability & 0.000 & 0.01 & 0.05 & 0.2 & 0.4 & 0.8 \\
\hline \multicolumn{7}{|c|}{ General regression information } \\
\hline Number of streamgages used to develop regression equation & 26 & 46 & 46 & 45 & 45 & 46 \\
\hline Standard deviation of model error, reported on log space & 0.058 & 0.018 & 0.012 & 0.075 & 0.102 & 0.261 \\
\hline $\begin{array}{l}\text { Coefficient of determination, asjusted for the number of predictor } \\
\text { variables, R-squared (adj) }\end{array}$ & 90.7 & 98.9 & 99.5 & 99.6 & 99.3 & 96.5 \\
\hline Constant term & 1.786 & -33.705 & -24.866 & 5.066 & 20.203 & 49.726 \\
\hline Drainage area & 0.820 & 0.938 & 0.978 & 0.994 & 1.031 & 1.048 \\
\hline Mean basin elevation & 0.451 & $* *$ & $* *$ & $* *$ & $* *$ & $* *$ \\
\hline Average annual precipitation & $* *$ & 2.539 & 2.129 & 0.949 & 0.750 & $* *$ \\
\hline Average maximum monthly temperature & $* *$ & $* *$ & $* *$ & $* *$ & $* *$ & -2.367 \\
\hline X-location of the basin outlet & $* *$ & $* *$ & $* *$ & 0.085 & 0.108 & $* *$ \\
\hline Y-location of the basin outlet & $* *$ & $* *$ & 1.345 & $* *$ & $* *$ & $* *$ \\
\hline Y-location of the basin centroid & $* *$ & 1.942 & $* *$ & -0.641 & -1.769 & -3.297 \\
\hline Bias correlation factor $\dagger$ & 1.030 & 1.010 & 1.002 & 1.003 & 1.004 & 1.031 \\
\hline
\end{tabular}

\section{Regression against Streamflow Quantiles}

Originally, 11 additional streamflow quantiles were regressed against physical and climate basin characteristics; however, because the regression equations were developed independently for streamflow quantiles at each of the exceedence probabilities, there was no constraint to ensure that estimated streamflows decreased with increasing exceedence probability. Thus the inherent structure of the data that ensures streamflow quantiles decrease with increasing exceedence probability is not preserved - a physical impossibility. To enforce physical consistency, 11 streamflow quantiles were recursively regressed against another estimated streamflow quantile. The process was done by first regressing one of the six streamflow quantiles estimated using basin characteristics against another quantile. This established an equation relating one quantile to another. The equations were then used to recursively estimate streamflow quantiles at 11 additional exceedence probabilities. For example, the streamflow quantile at the 80 -percent exceedence probability is obtained by solving a quantile-based regression equation that is a function of basin characteristics. However, the streamflow quantile at the 85 -percent exceedence probability is obtained using the relation between the streamflow quantiles at the 80 and 85-percent exceedence probabilities. Only the estimated streamflow at the 80-percent exceedence probability is needed to estimate the streamflow at the 85-percent exceedence probability. Subsequent streamflow quantiles are estimated from the relation between one quantile and another (table 5). After streamflow quantiles at the 17 exceedence probabilities are solved, streamflow is log-linearly interpolated between these quantiles to obtain a continuous, daily FDC.

\section{Estimation of Streamflow Time Series by use of a Reference Streamgage}

The MA SYE tool transforms the daily mean FDC at an ungaged site to a time series of daily mean streamflow using the QPPQ method (Fennessey, 1994; Hughes and Smakhtin, 1996; Smakhtin, 1999; Smakhtin and Masse, 2000; Mohamoud, 2008). The QPPQ method uses a reference streamgage to assign a date to each streamflow quantile along the estimated FDC by relating the exceedence probabilities at the ungaged site to the reference streamgage (fig. 1). 


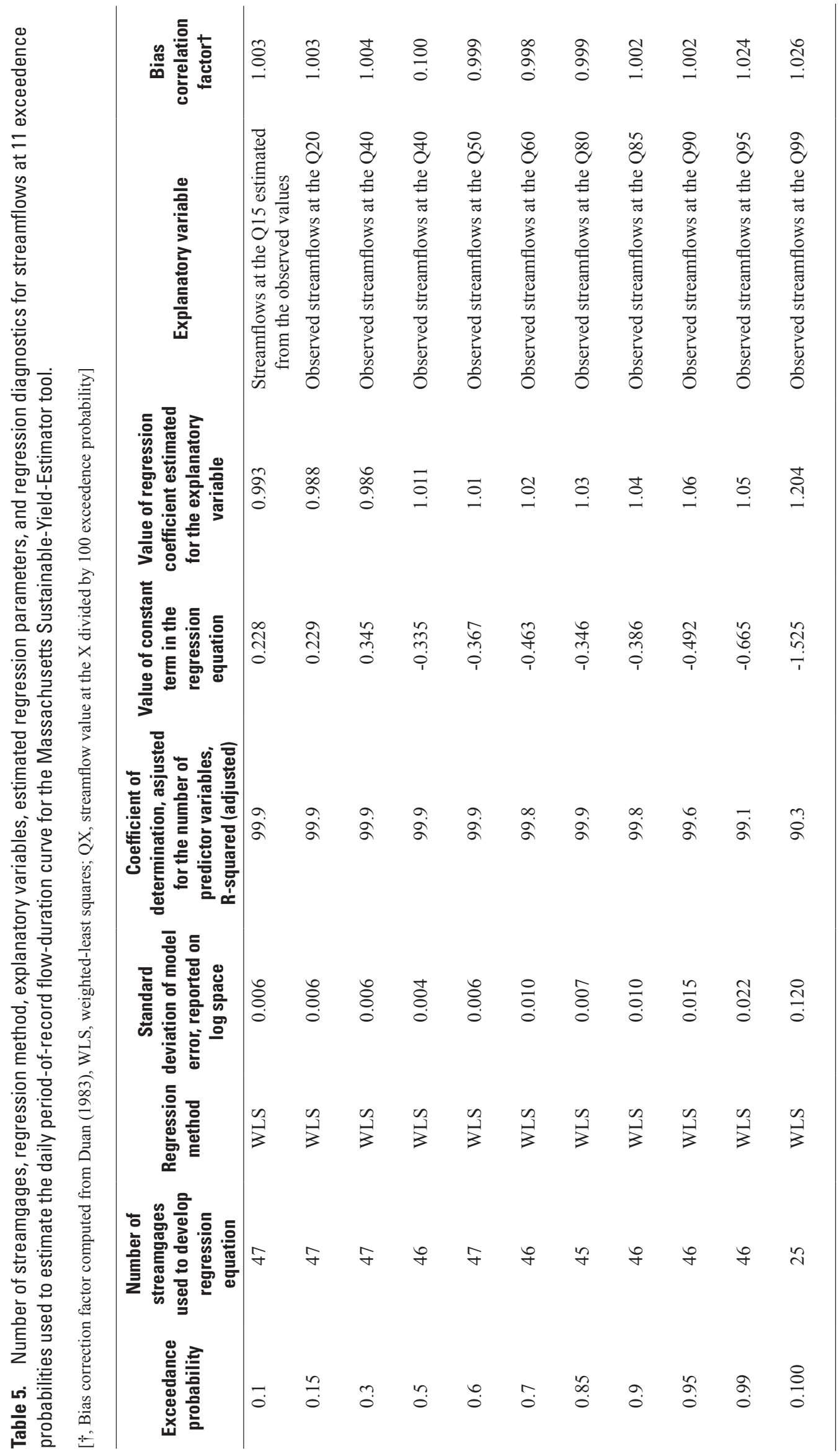




\section{Reference Streamgages}

The MA SYE tool selects a reference streamgage from 1 of 66 reference streamgages across southern New England (table 1; fig. 3). The reference streamgages include the 61 streamgages used by Armstrong and others (2008) to hydrologically classify Massachusetts streams and 5 additional streamgages that are also considered unregulated by Armstrong and others (2008), which enhanced the number of reference streamgages.

The QPPQ method requires that the reference streamgage and ungaged site have daily streamflow records for the time period of interest. Therefore, all reference streamgages in the MA SYE also must have records of 16,071 daily streamflows spanning October 1, 1960 through September 30, 2004. Therefore, the records for 50 of the 66 reference streamgages were extended using the MOVE. 3 technique (Vogel and Stedinger, 1985) to ensure all reference streamgages had a period of streamflow record from October 1, 1960, through September 20, 2004. It is important to note that the streamflow values at the reference streamgage are not used in the QPPQ method; only the date and exceedence probabilities at the reference streamgage are used. Record extension for these streamgages followed the approach detailed in Armstrong and others (2008). Information on the record extension for 46 of the 50 reference streamgages is located in Armstrong and others (2008); record-extension information for the additional 4 reference streamgages is listed in table 6 of this report.

\section{Selection of a Reference Streamgage}

For the QPPQ method, it is assumed that the date of a particular streamflow being exceeded at the ungaged site is the same as at the reference streamgage. For example, if the streamflow on October 1, 1974, is exceeded 95 percent of the time at the reference streamgage, the streamflow exceeded 95 percent of the time at the ungaged site also occurred on October 1, 1974. By extension to other streamflow quantiles, for the QPPQ method it is assumed that the high-flow, midrange flow, and low-flow events occur on the same day at both the reference streamgage and the ungaged site. Therefore, the ideal reference streamgage would be the one with the most streamflows correlated to those at the ungaged site. The MA SYE tool quantifies the correlation between the timing of the streamflows at 66 reference streamgages and those at the ungaged site by use of the Pearson $r$ correlation coefficient (Helsel and Hirsch, 1992). The assumption of equivalent exceedence probabilities occurring on the same day is more likely to hold for two sites that have a value of Pearson $r$ correlation coefficient close to one, which means the high-flow, mid-range flow, and low-flow events occur on exactly the same day at both the reference streamgage and the ungaged site.

Although the Pearson $r$ correlation coefficient value is easily computed for two gaged sites, the Pearson $r$ correlation coefficient value cannot be directly measured for streamflows at a gaged and ungaged site. For this reason, the MA

Table 6. Description of MOVE.3 (Vogel and Stedinger, 1985) record extension for four U.S. Geological Survey reference streamgages in the New England study area.

[These four reference streamgages were not used in Armstrong and others (2008). MOVE.3, Maintenance of Varience Extension, type-3]

\begin{tabular}{|c|c|c|c|c|}
\hline $\begin{array}{l}\text { Streamgage } \\
\text { number }\end{array}$ & Streamgage name & $\begin{array}{l}\text { Streamgage(s) used for MOVE.3 } \\
\text { record extension }\end{array}$ & $\begin{array}{l}\text { Correlation } \\
\text { coefficient }\end{array}$ & $\begin{array}{l}\text { Period of } \\
\text { extension }\end{array}$ \\
\hline \multirow[t]{2}{*}{01086000} & Warner River near Davisville, NH & Soucook River near Concord, NH (01089000) & 0.95 & $1979-1987$ \\
\hline & & $\begin{array}{l}\text { Soucook River at Pembroke Road near Con- } \\
\text { cord, NH (01089100) }\end{array}$ & 0.97 & 1988-2001 \\
\hline 01180000 & Sykes Brook at Knightville, MA & West Branch Westfield River 01181000) & 0.97 & 1975-2004 \\
\hline 01107000 & Dorchester Brook near Brockton, MA & Wading River near Norton, MA (01109000) & 0.93 & $\begin{array}{l}1960-1962 \\
1974-2004\end{array}$ \\
\hline
\end{tabular}




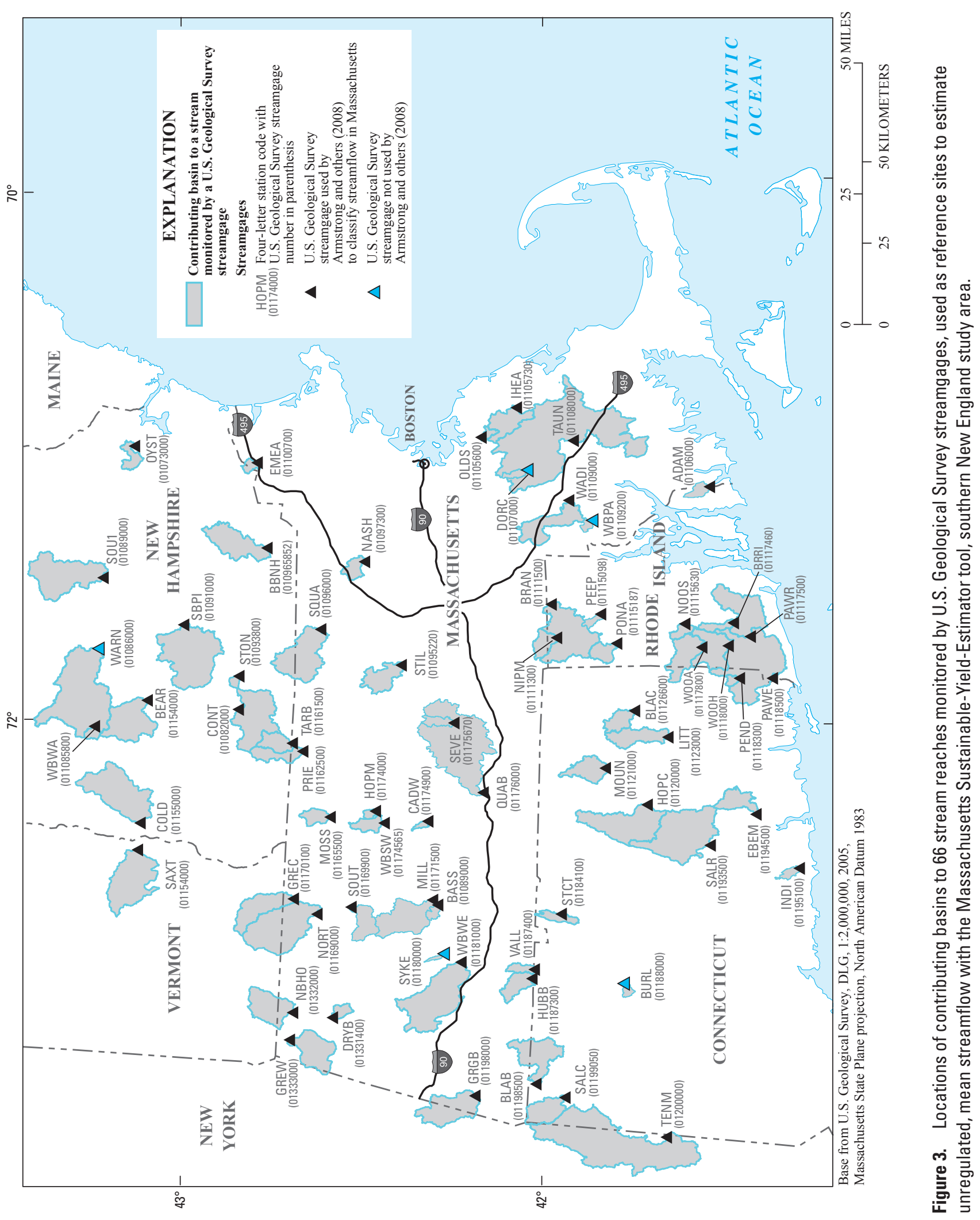


SYE estimates the correlation between the natural log of the streamflows at the ungaged site and each potential reference streamgage to select the reference streamgage for which logarithms of the daily streamflow are estimated to have the highest correlation with the logarithms of the daily streamflows at the ungaged site.

Time-series correlations between the ungaged site and each reference streamgage were obtained through kriging (Isaaks and Srivastava, 1989), a geostatistical method. For a given reference streamgage, the Pearson $r$ correlation coefficient value was computed from the logarithms of the observed, concurrent daily streamflows at the given reference streamgage and each of the other reference streamgages used by the MA SYE tool. A spherical variogram model (Isaaks and Srivastava, 1989) was then developed for each reference streamgage to quantify the relation between the distances between each pair of reference streamgages and the differences in the Pearson $r$ correlation coefficient values between each pair of reference streamgages. Each variogram model quantifies the Pearson $r$ correlation-coefficient value for any ungaged site in relation to a reference streamgage. The reference streamgage with the highest Pearson $r$ correlation coefficient value in relation to the ungaged site is selected for use with the QPPQ method. The MA SYE tool requires only the Massachusetts State-Plane coordinates of the ungaged site in order to select the reference streamgage. The variogram models can be used to create prediction maps of the Pearson $r$ correlation coefficient value for each reference streamgage, which show the correlation between a reference streamgage and any ungaged site in Massachusetts (fig. 4). For the CADW 01174900 streamgage (fig. 4A), the areas with the higher estimated correlations form an ellipsoid with the major axis trending in the southwest-northeast direction; however, for the STIL 01095220 streamgage (fig. 4B), correlations appear to decrease radially with distance. Archfield (2009) provides a detailed explanation and validation of the variogram models.

\section{Comparison of Observed and Estimated Streamflows}

A time series of unregulated, daily mean streamflow at an ungaged site is assembled in the following steps: (1) solve the regression equations, (2) interpolate between the regressionestimated streamflow quantiles to obtain a daily FDC at the ungaged site, (3) select the reference streamgage, and (4) apply the QPPQ method. To evaluate the MA SYE tool for use in estimating daily, unregulated streamflows at an ungaged site, a validation procedure was used at 18 streamgages because observed streamflow for the period-of-record of interest (October 1, 1960, to September 30, 2004) was available for these streamgages (fig. 2 and table 1). For each of the 18 streamgages, the FDC regression equations were re-developed independent of the streamgage, and the selection of the reference streamgage did not include the streamgage used in the kriging procedure. In effect, this validation experiment evaluates the estimates of streamflow at a streamgage that was not used in the development of the MA SYE tool. The 18 streamgages used in the cross-validation are representative of the distribution of basin characteristics at the 47 streamgages used to develop the continuous, daily FDC (fig. 5).

Observed and estimated streamflows were then compared for goodness of fit at each of the removed streamgages, and a Nash-Sutcliffe (NS) efficiency value (Nash and Sutcliffe, 1970 ) and percent root-mean-square-error (RMSE) values were computed for each of the 18 streamgages using the natural-log values of the observed and estimated daily streamflows. NS values ranged from 0.98 to 0.69 , with a median value of 0.86 (fig. 6); percent RMSE values ranged from 19 to 284 percent, with a median value of 55 percent (fig. 6). Observed and estimated annual, monthly, and daily mean streamflows for streamgages with the best and worst agreement over the full 44-year period show good agreement and relatively unbiased results (fig. 7). However, the highest and lowest daily mean streamflows appear to show a "hook" feature (fig. 7E and 7F). The hook feature is likely an artifact of the log-linear interpolation among the 17 regression-estimated streamflows. Observed and estimated FDCs, when examined at the highest and lowest streamflows, show that the assumption of a loglinear relation between streamflow quantiles at the highest and lowest streamflows may not be appropriate (fig. 8). Nevertheless, these flows represent only the 160 days of highest flow and the 160 days of lowest flow; the other 15,751 streamflows were estimated reasonably by the MA SYE tool.

A comparison of observed and estimated hydrographs for streamgages with the best $(01187300$, Hubbard River near West Harland, CT (HUBB)) and worst (01188000, Burlington Brook near Burlington, CT (BURL)) agreement over the period October 1, 1960, through September 30, 1962-the period of time at the start of the worst drought of recordshow good agreement in both real and log space (fig. 9A and 9B). Differences between the observed and estimated daily mean streamflow shown for the 18 streamgages are likely to be typical of the differences one could expect when using the MA SYE tool because the range of basin characteristics for the 18 streamgages used in the cross-validation experiment are nearly identical to the range of these characteristics at the 47 streamgages from which the regression equations were developed (fig. 5).

Streamflow estimates at 29 streamgages used in the development of the MA SYE quantile-based regressions overlapped with those for the streamgages used by Ries and Friesz (2000) (table 1 identifies these 29 streamgages). The estimated streamflow quantiles from the MA SYE tool were compared with the observed streamflow quantiles and the Massachusetts StreamStats-estimated streamflow quantiles estimated at the $0.50,0.60,0.70,0.80,0.85,0.9,0.95$, and 0.99 exceedence probabilities by Ries and Friesz (2000) and used in the Massachusetts StreamStats equations. Before making the comparison at each streamgage, the streamgage was were removed from the MA SYE equations, and the regression coefficients were re-estimated. This ensured that the MA SYE-estimated streamflow quantile was not affected by the inclusion of this 


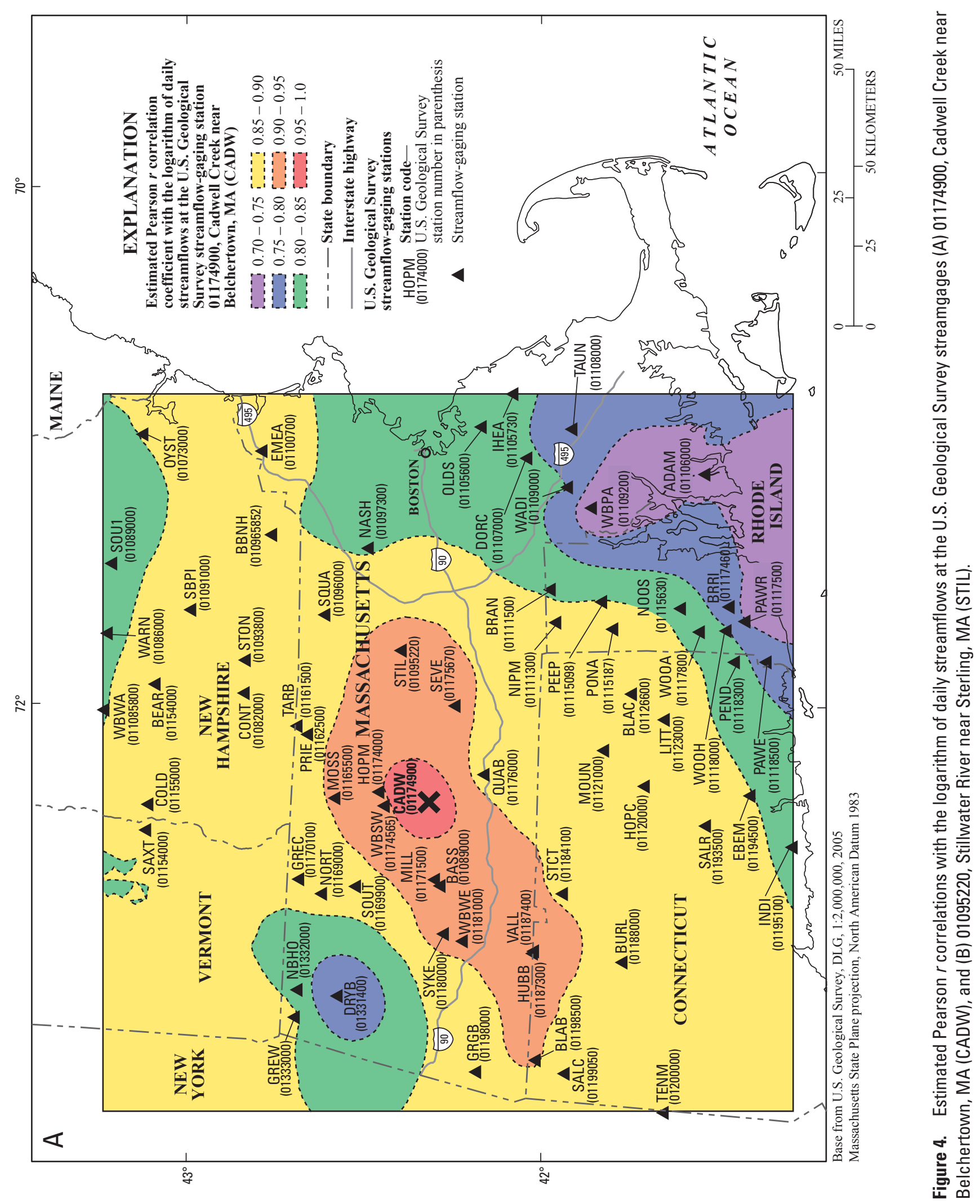




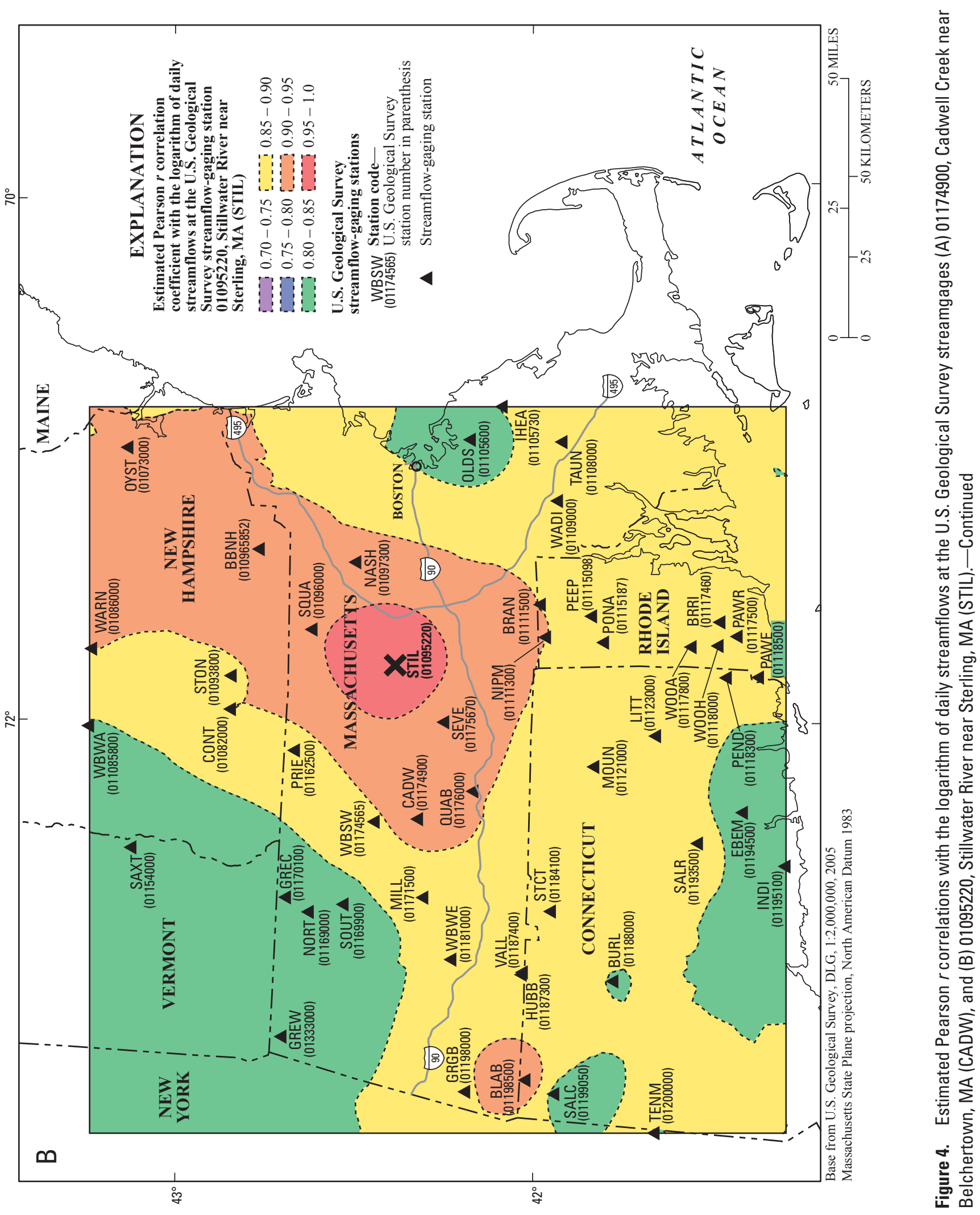



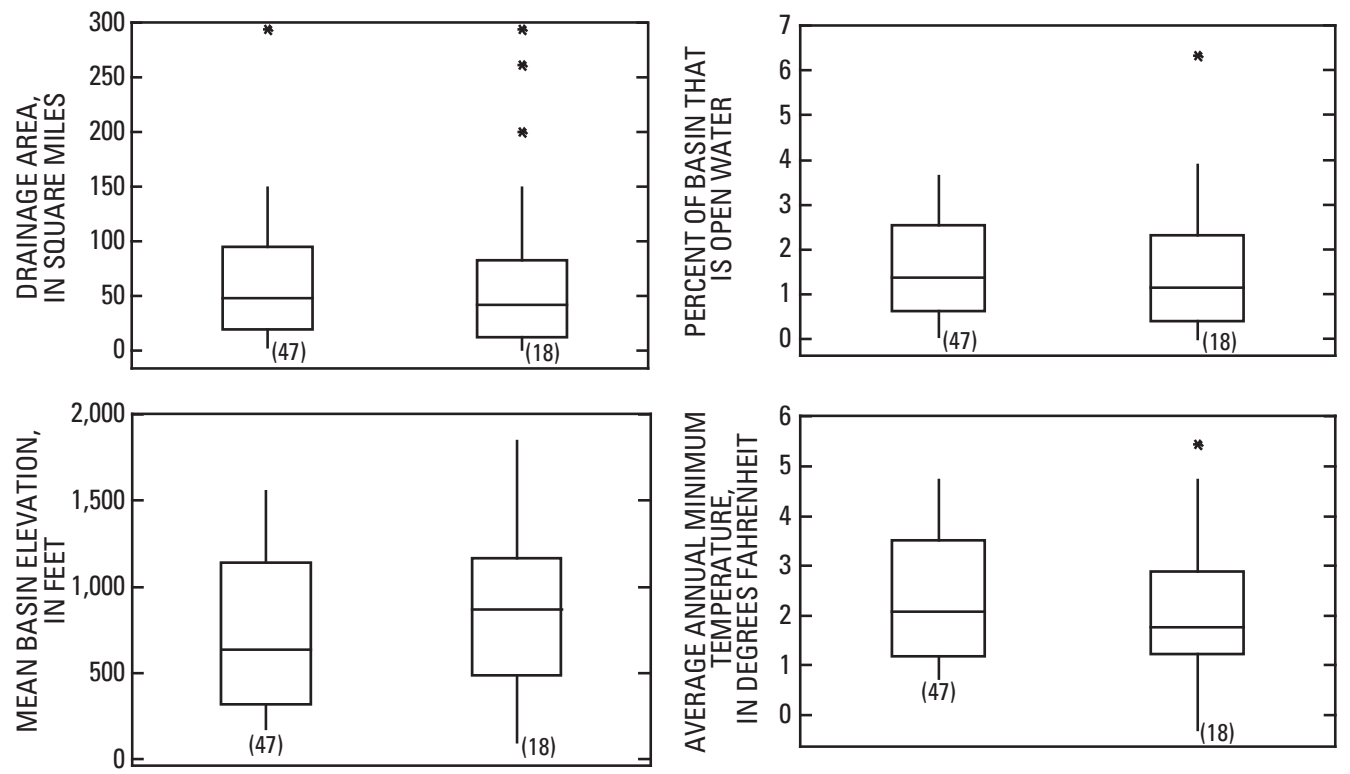

EXPLANATION

Upper limit (75th percentile +1.5 * (75th percentile - 25th percentile))

75th percentile

Median

25th percentile

Lower limit (25th percentile +1.5 * (75th percentile - 25th percentile))

* Values above the upper limit or below the lower limit

(18) Sample size
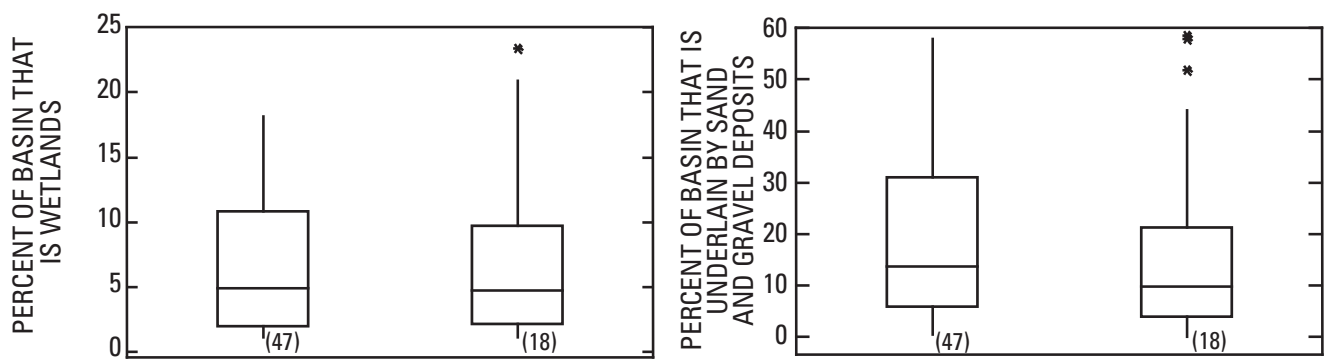

Figure 5. Distribution of basin characteristics used in six regression equations to estimate unregulated, daily mean streamflow at selected streamflow quantiles and range of characteristics used to validate the estimated mean, daily streamflows computed by the Massachusetts Sustainable-Yield Estimator (MA SYE) tool.
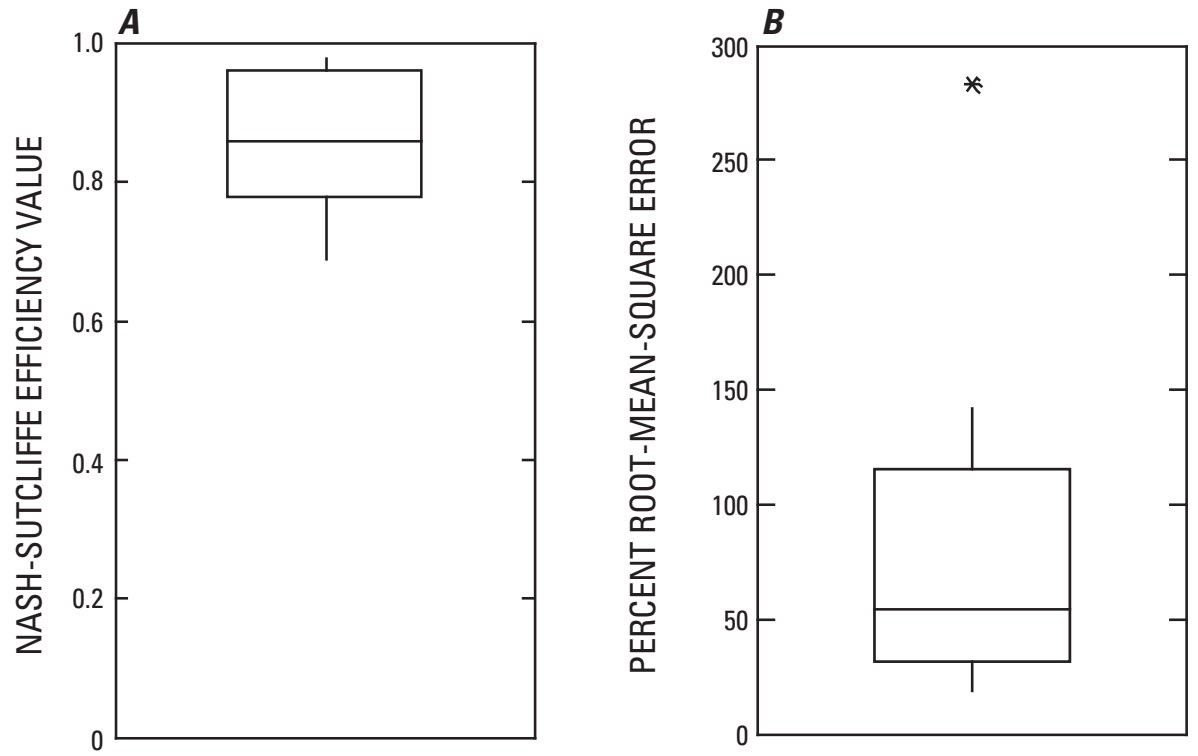

\section{EXPLANATION}

Upper limit (75th percentile $+1.5^{*}$ (75th percentile - 25th percentile))

75th percentile

Median

25th percentile

Lower limit (25th percentile $+1.5^{*}$

(75th percentile -25 th percentile))

* Values above the upper limit or below the lower limit

Figure 6. Distribution of goodness-of-fit statistics, (A) Nash-Sutcliffe efficiency values and (B) percent root-mean-square error, computed from observed and estimate mean, daily streamflow values at 18 U.S. Geological Survey streamgages. 

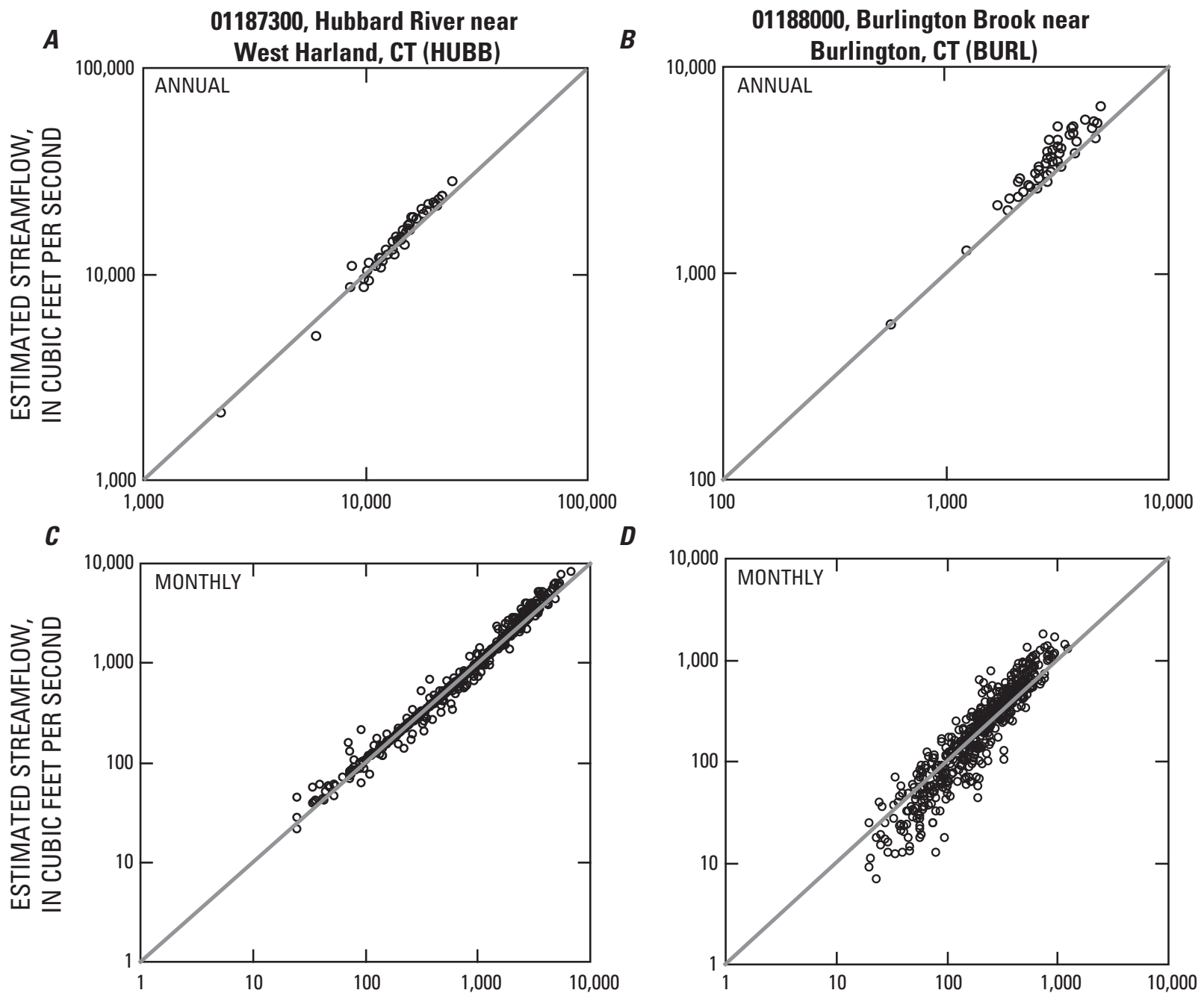

D
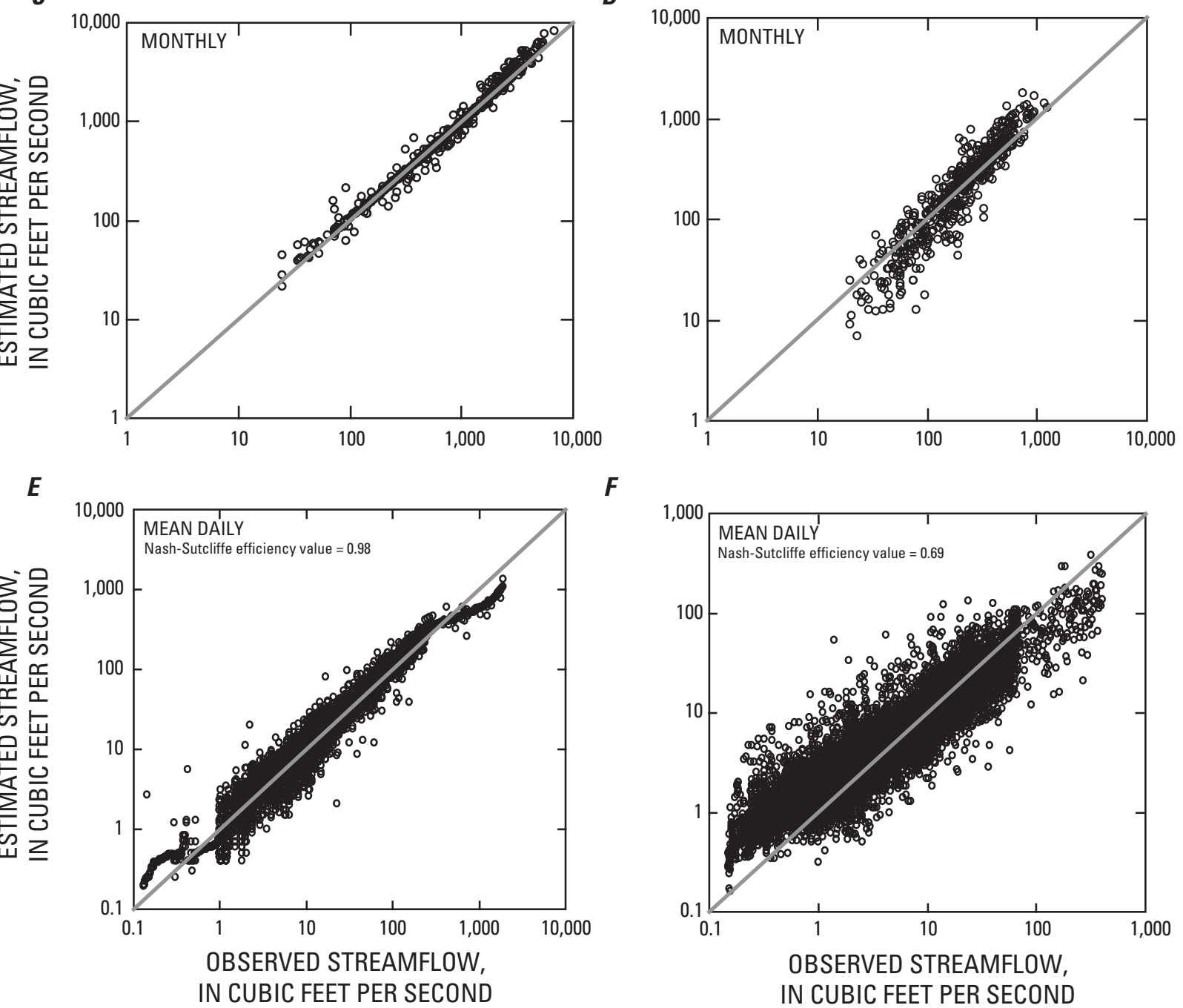

$\boldsymbol{F}$

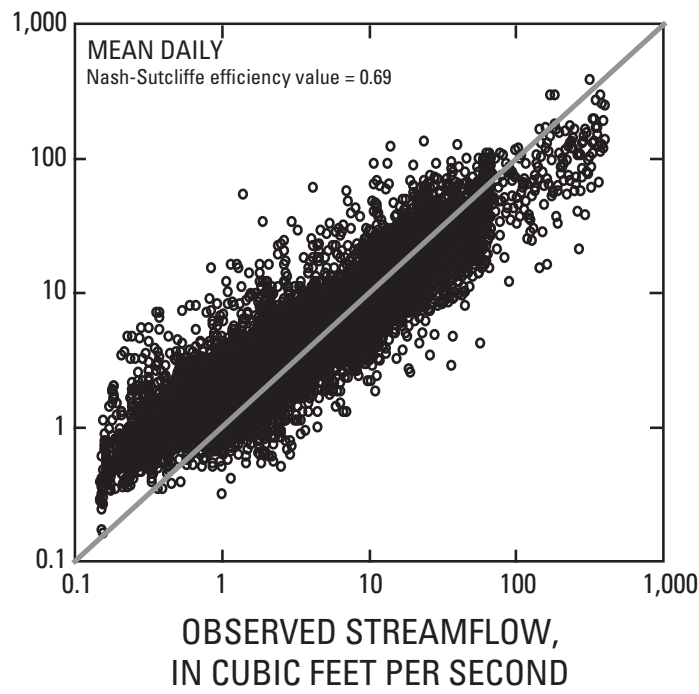

Figure 7. Observed and estimated (A-B) annual, (C-D) monthly, and (E-F) daily mean streamflows for U.S. Geological Survey streamgages 01187300, Hubbard River near West Harland, CT (HUBB) and 01188000, Burlington Brook near Burlington, CT (BURL), southern New England study area, 1960-2004. 


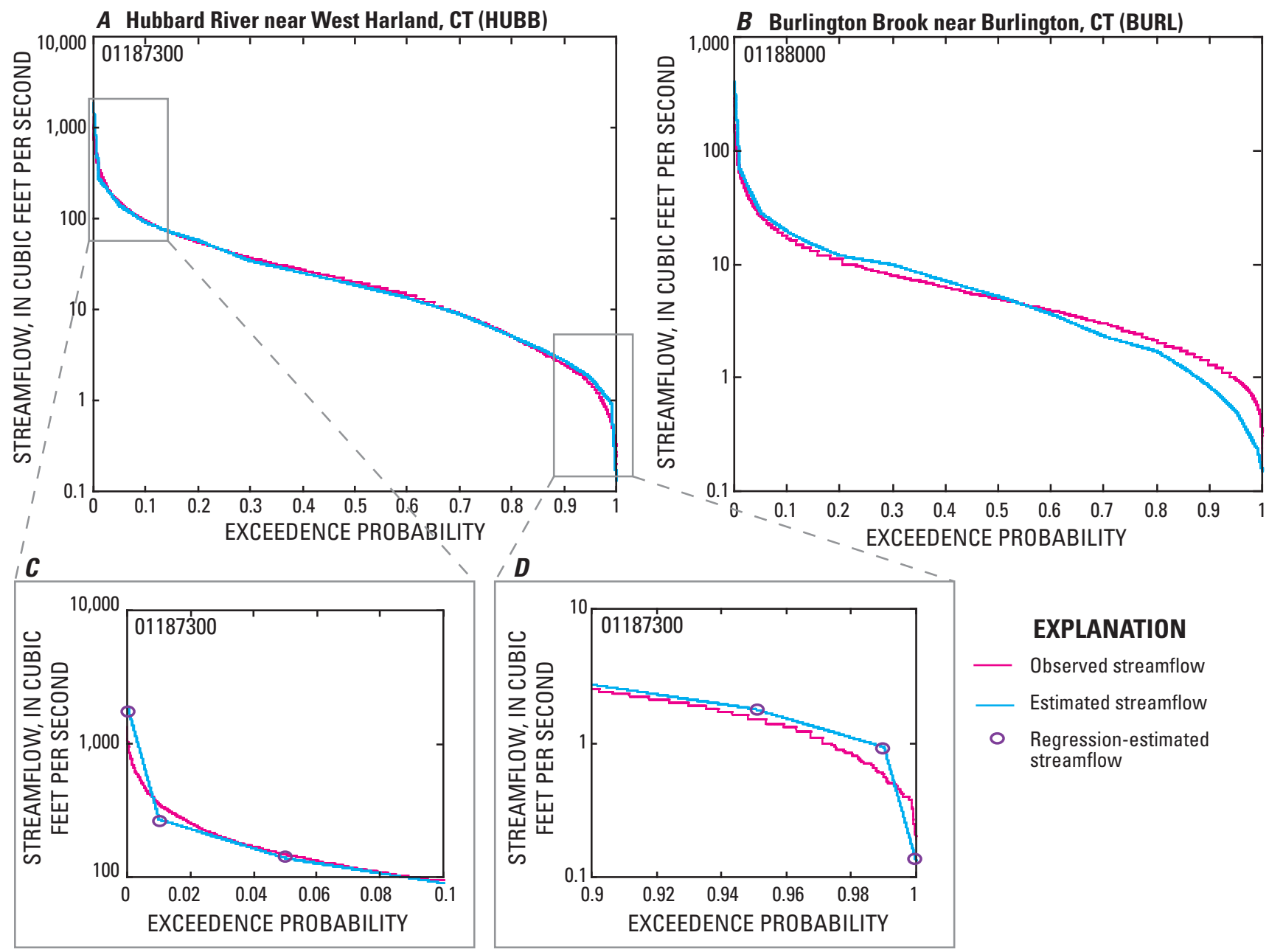

Figure 8. Observed and estimated streamflow quantiles by exceedence probability for U.S. Geological Survey streamgages (A, C, and D) 01187300, Hubbard River near West Harland, CT (HUBB) and (B) 01188000, Burlington Brook near Burlington, CT (BURL), southern New England study area.

streamgage in the development of the equation. However, it was not possible to perform this operation on the equations developed by Ries and Friesz (2000); therefore, a rigorous comparison of the MA SYE and Massachusetts StreamStats could not be conducted. In all cases evaluated, however, the MA SYE-estimated streamflow quantiles were consistent with the observed streamflow quantiles and the streamflow quantiles estimated by the Massachusetts StreamStats equations (Ries and Friesz, 2000) (fig. 10). Furthermore, all MA SYEestimated streamflow values at each of the 29 streamgages fell within the 90 -percent confidence intervals reported by Ries and Friesz (2000).

\section{Uncertainty of Estimated Streamflows}

The uncertainty associated with estimated time series of unregulated, daily mean flow at an ungaged site involves three major components: (1) estimation of the FDC at the ungaged site, (2) choice of a reference streamgage based on maps of cross-correlations among flow records of existing gaged sites, and (3) transfer of daily streamflows from the reference streamgage to the ungaged site using the QPPQ method and its inherent assumptions. Each of these major components adds unique uncertainty to the estimated streamflows at the ungaged site, in addition to the measurement error associated with the observed streamflows used to develop the regression equations and the selection and use of the reference streamgage.

A rigorous uncertainty analysis would incorporate the uncertainty introduced by each of these sources of error in an integrated fashion that would result in prediction intervals that enclose the estimated unregulated, daily mean streamflows within a stated degree of confidence. If the MA SYE tool were based on a single modeling approach, such as the multivariate regression used in Ries and Friesz (2000), or a physically based model, one could employ standard methods 


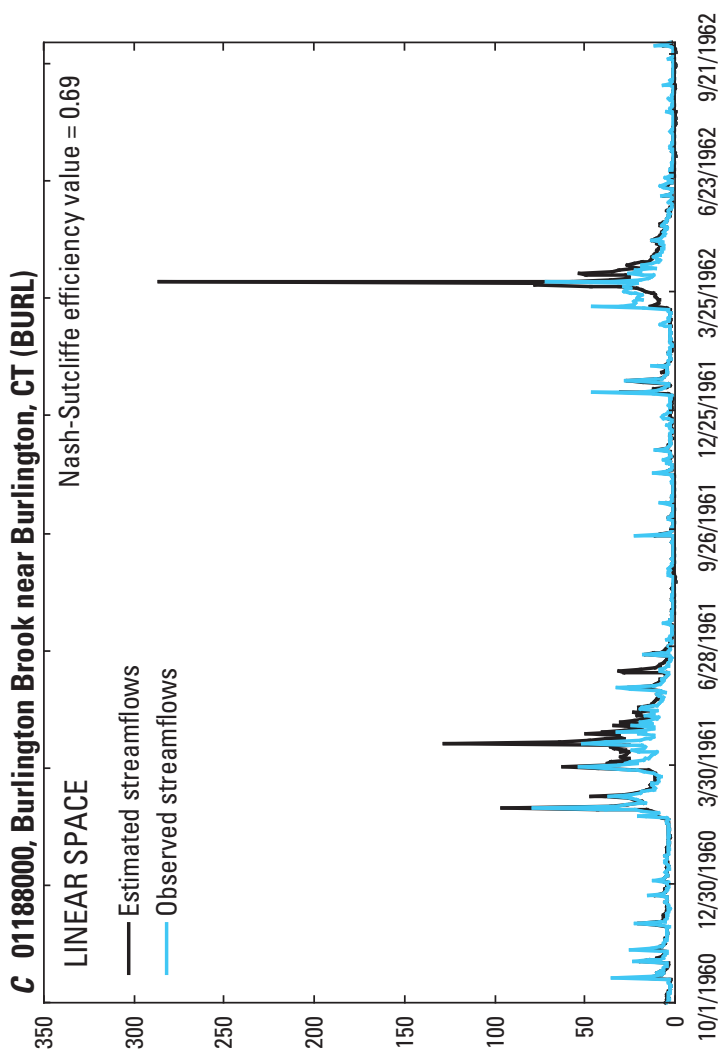

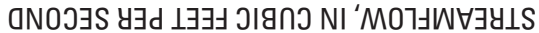
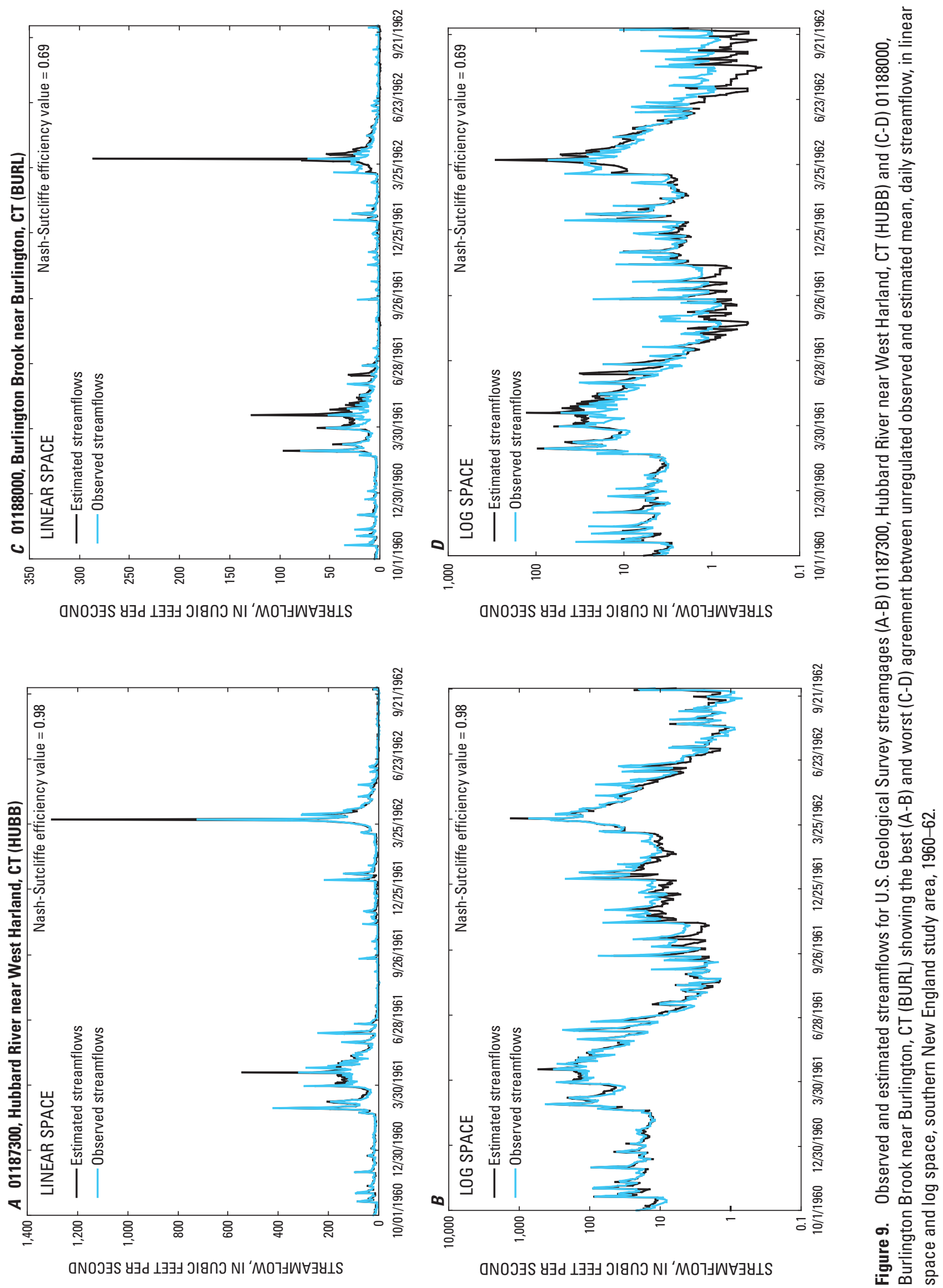

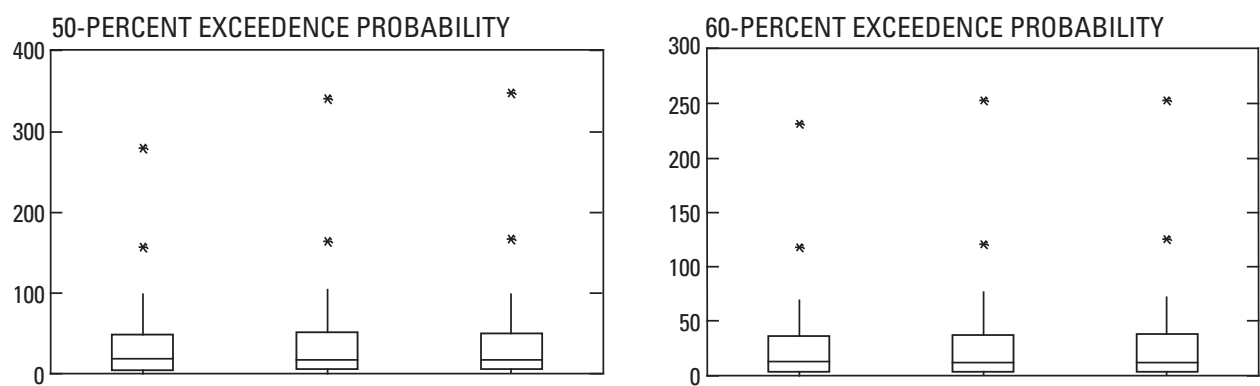

\section{EXPLANATION}

limit 75 th percentile $+1.5 *$

(75th percentile - 25th percentile))

75th percentile

Median

25th percentile

Lower limit (25th percentile $+1.5 *$ (75th percentile - 25 th percentile))
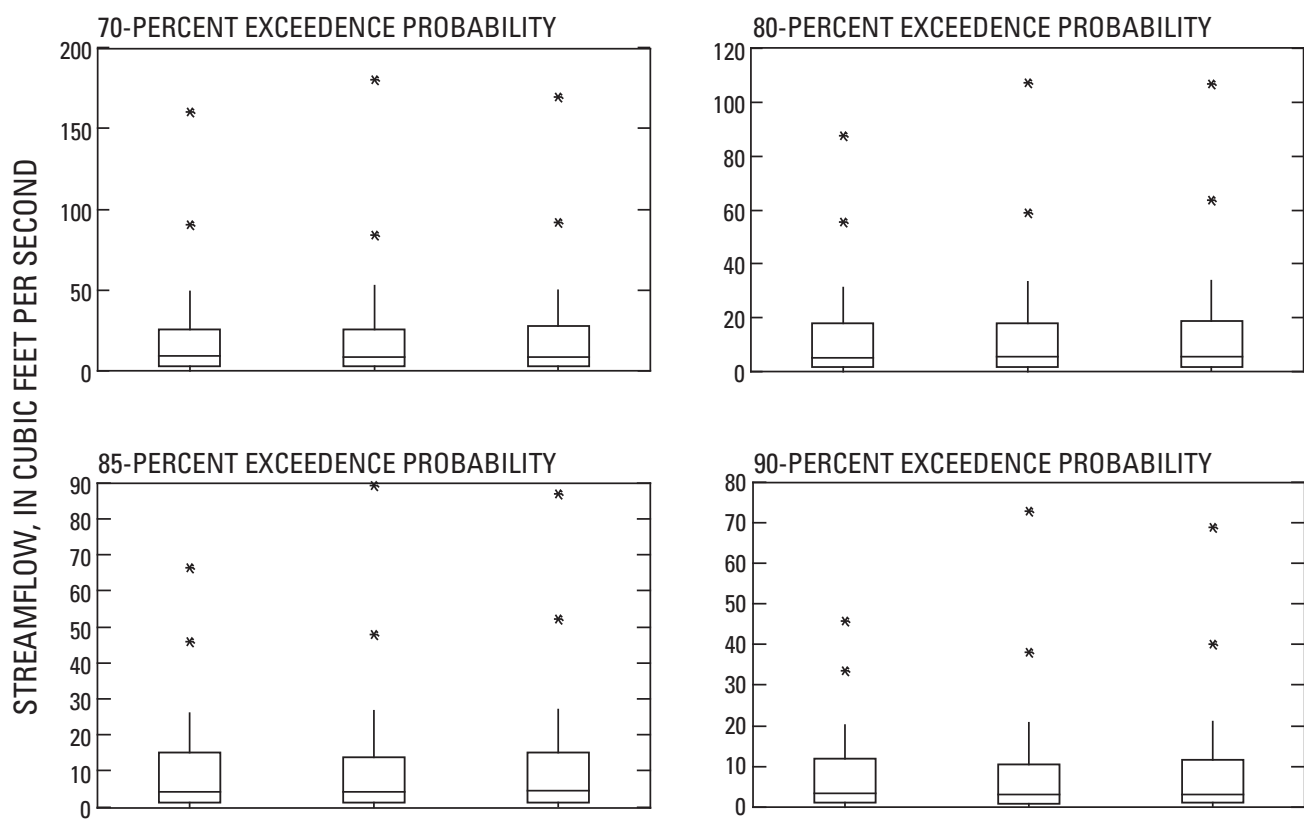

Values above the upper limit or below the lower limit
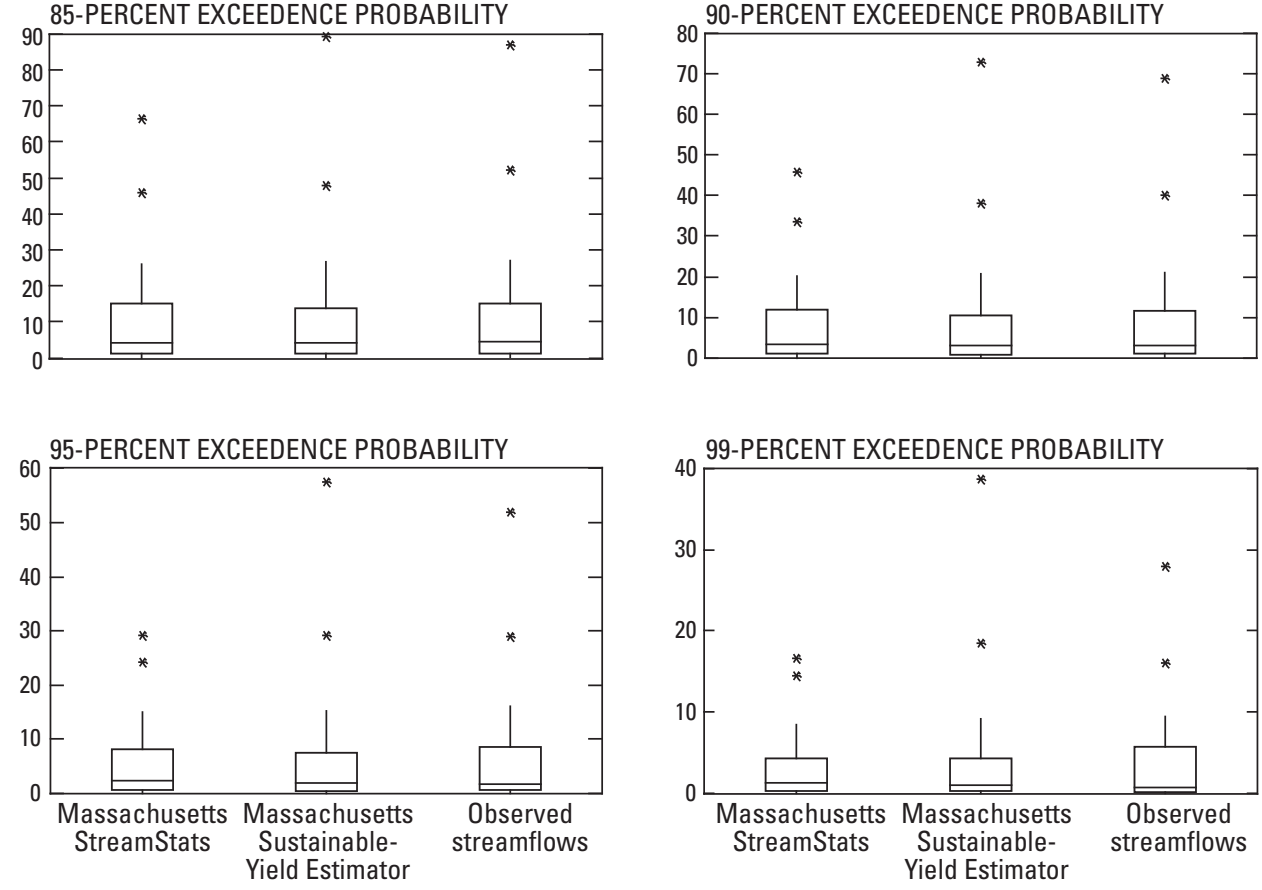

Figure 10. Distribution of observed streamflow and streamflow estimated by the Massachusetts StreamStats and Massachusetts Sustainable-Yield-Estimator tool for eight exceedence probabilities at 29 U.S. Geological Survey streamgages in Massachusetts. 
of uncertainty analysis for such model predictions. However, the estimated streamflows used in the MA SYE tool are derived from a variety of complex modeling steps so the standard methods of uncertainty analysis do not provide meaningful prediction intervals. Identifying the true uncertainty is unusually challenging given the interaction of the major MA SYE components. For example, employing the widely used method termed "generalized likelihood uncertainty estimation" (GLUE) (see Stedinger and others, 2008) does not suffice for this problem because GLUE applies only to physically based models, and there are many more sources of error in addition to the model parameter errors accounted for in a GLUE methodology. The actual uncertainty of the MA SYE-estimated streamflows is unknown and remains an area for future research.

To address the issue of uncertainty in this report, the conditions under which one can be expected to obtain the type of goodness-of-fit values reported (fig. 6) are documented. Because the goodness-of-fit values are based on rigorous cross-validation experiments, they represent the range of uncertainty that one can expect in future applications of the MA SYE tool at ungaged sites. For example, figure 6 demonstrates the use of cross-validation experiments, and shows that the use of the estimated time series of daily streamflows that resulted from the goodness-of-fit test generated NS efficiency values in the range of 0.69 to 0.98 with a median value of approximately 0.86 . In other words, the range of uncertainty expected from future applications of the MA SYE at ungaged sites will vary across the spectrum of estimated daily streamflows as illustrated by the distribution NS efficiency values reported in figure 6 and time-series plots depicted in figure 9.

In a particular application of the MA SYE tool, the question will arise as to what would be the expected value of the NS efficiency value at an ungaged site. Multivariate ordinary least squares regression was employed to develop a predictive model for values of NS efficiency as a function of the information that would be available to the user of the MA SYE. The two key factors which drive our overall ability to transfer information from a reference streamgage to an ungaged site are the degree of correlation, $\rho$, between the natural logarithms of the daily streamflows at each site and the variability of the streamflows at the ungaged site. Here the variability of the daily streamflows is measured using the standard deviation of the natural logarithms of the daily streamflows denoted as $\sigma$. Note that for a lognormal variable $\mathrm{x}$, its coefficient of variation depends only on $\sigma_{\mathrm{y}}$ where $\mathrm{y}=\ln (\mathrm{x})$.

Because the efficiency values for reasonable models cannot exceed unity, logit, probit and complementary log-log models (see McCullagh and Nelder, 1983; and Agresti, 1990) were fit to the efficiency values, and all the models restricted predicted values of efficiency to be less than unity. Of the three candidate transformations, the probit model produced the most favorable results in terms of overall goodness-of-fit. A probit model was developed using multivariate ordinary least squares regression to fit the model

$$
\Phi^{-1}(E)=\beta_{0}+\beta_{1} \rho+\beta_{2} \sigma_{y}
$$

where

$\Phi^{-1}(E) \quad$ is the inverse of a standard normal distribution evaluated at NS efficiency, E,

$\beta_{0} \quad$ is the regression-estimated constant term,

$\rho \quad$ is the correlation between the natural

logarithms of the daily streamflows at each site,

$\beta_{1} \quad$ is the regression estimated coefficient for $\rho$,

$\sigma_{y} \quad$ is the standard deviation of the natural

logarithms of the daily streamflows, and

$\beta_{2} \quad$ is the regression estimated coefficient for $\sigma_{\mathrm{y}}$.

The resulting model, inverted to obtain an estimate of NS efficiency is

$$
\mathrm{E}=\Phi\left[-14.388+14.033 \rho+1.9722 \sigma_{\mathrm{y}}\right]
$$

where now $\Phi($ ) is the cumulative distribution function for a standard normal random variable. The t-ratios of the model parameters $\beta_{0}, \beta_{1}, \beta_{2}$ are $-3.08,3.02$ and 3.89, respectively, leading to p-values of 0.008, 0.009 and 0.001 , respectively. The model has an adjusted $\mathrm{R}^{2}$ value equal to 48.4 with model residuals which are extremely well approximated by a normal distribution. A comparison of the values of NS efficiency estimated from the cross-validation experiments and those estimated using equation (3) is shown in figure 11.

The regression model shown in equation (3) documents how average values of goodness of fit vary with both $\rho$ and

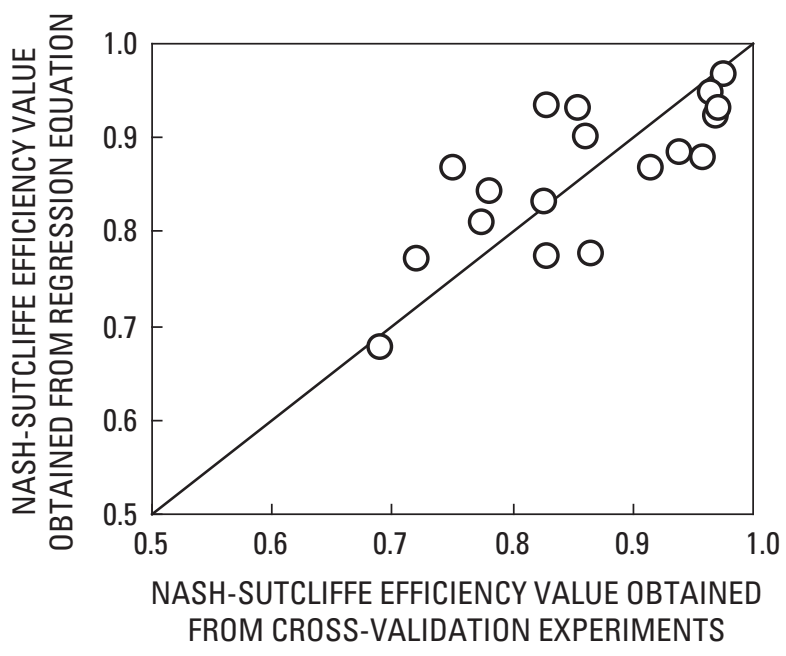

Figure 11. Nash-Sutcliffe efficiency values obtained from the cross-validation experiments in relation to values obtained from regression equations to estimate uncertainty in the daily unregulated streamflows estimated by the Massachusetts Sustainable-Yield-Estimator tool. 
$\sigma_{y^{\prime}}$ In general, one expects the NS efficiency value to increase as the correlation between the reference streamgage and the ungaged site increases because that correlation reflects the overall similarity between the two sites. One also expects values of NS efficiency to increase for ungaged sites which have greater overall flow variability because the FDC regression equations have greater predictive capability in such cases. The greater predictive capability associated with the FDC regression equations relate to the recursive nature of the regressions. As $\sigma_{y}$ increases, the quantiles of the FDC show greater correlation with each other, which results in recursive regressions with higher explanatory power. An open question remains as to what conditions would lead the QPPQ method to yield higher values of NS efficiency. Further research is needed to better understand these issues.

The t-ratios associated with $\rho$ and $\sigma_{\mathrm{y}}$ reflect the fact that $\sigma_{\mathrm{y}}$ explains somewhat more of the overall variability in values of NS efficiency than $\rho$. The effect attributable to $\rho$ could be caused largely by the choice of a reference streamgage, whereas the effects due to $\sigma_{\mathrm{y}}$ are due largely to the transfer of streamflow using the QPPQ method and the estimation of the FDC at the ungaged site using regression methods. Thus the regression in equation (3) seems to indicate that more accurate streamflow estimates will likely result from improvements in all three of the major steps associated with the SYE methodology.

\section{Streamflow Adjusted for Groundwater and Surface-Water Withdrawals and Discharges}

The MA SYE tool can modify estimates of unregulated, daily mean streamflow at an ungaged site on the basis of permitted groundwater and surface-water withdrawal and discharge locations contained within the basin of interest. For a user-selected basin, groundwater and surface-water withdrawals and discharges are subtracted and added, respectively, from the unregulated, daily streamflow to obtain a time series of daily streamflow at an ungaged site that has been adjusted by the reported 2000 through 2004 withdrawal and discharge volumes. Users also have the option to apply an analytical solution to time-varying groundwater withdrawals and discharges that incorporate the effects of the aquifer properties on the timing and magnitude of streamflow alteration.

\section{Reported Groundwater and Surface-Water Withdrawals and Discharges}

A statewide, spatially referenced database of groundwater and surface-water withdrawals and groundwater discharges from 2000 through 2004 was provided by the Massachusetts
Geographic Information System (MassGIS) and MassDEP (Christian Jacques, Massachusetts Geographic Information System, written commun., 2007; Thomas Lamonte and Kari Winfield, Massachusetts Department of Environmental Protection, written commun., 2008). The U. S. Environmental Protection Agency (USEPA) provided the National Pollutant Discharge Elimination System (NPDES) surface-water discharge locations and volumes for 2000 through 2004, which are also included in the statewide database.

The database of withdrawals and discharges contains 6,581 locations of groundwater and surface-water withdrawals and discharges in Massachusetts (fig. 12 and table 7), covering four major categories: (1) groundwater and surface-water public-water-supply withdrawals, including community, noncommunity, and transient facilities using less than 100,000 gallons per day; (2) groundwater and surface-water withdrawals greater than 100,000 gallons per day use as regulated by the Massachusetts Water Management Act (M.G.L. c. 21G), including public and non-public water suppliers (examples of the latter include golf courses and agricultural, commercial, and industrial facilities supplying water for non-human consumption); (3) groundwater pollutant discharges greater than 10,000 gallons per day as regulated by MassDEP (M.G.L. 310 CMR 5), including discharges of sanitary sewer, industrial non-contact cooling waters, Laundromat and carwash waters, and water used in groundwater-treatment systems; and (4) NPDES surface-water discharges as regulated by the USEPA.

Volumes of withdrawal and discharge are available for public-water-supply withdrawals, groundwater discharges, and NPDES surface-water discharges. Public- and non-public water-supply withdrawals greater than 100,000 gallons per day (withdrawals regulated by the WMA) are managed as a withdrawal system, and therefore, withdrawal volumes are reported as the sum of all sources within a withdrawal system, not by individual withdrawal source. Some withdrawal systems are comprised of only public-water-supply withdrawals, in which case, source volumes are also available; however, some withdrawal systems are a combination of public- and non-public-water-supply withdrawals (some withdrawal volumes are available by withdrawal source) and some are only non-public-water-supply withdrawals (no withdrawal volumes are available by withdrawal source). For withdrawal systems that contain both public- and non-public-water-supply withdrawal locations, the source-level withdrawals are subtracted from the total reported withdrawal volume for the system, and the remaining system withdrawal volumes are divided equally among the non-public-water-supply withdrawals to obtain source volumes for each withdrawal location in the system. For withdrawal systems that contain only non-public-watersupply withdrawal locations, the system withdrawal volumes are divided equally among the non-public-water-supply withdrawals to obtain source volumes for each withdrawal location in the system. 


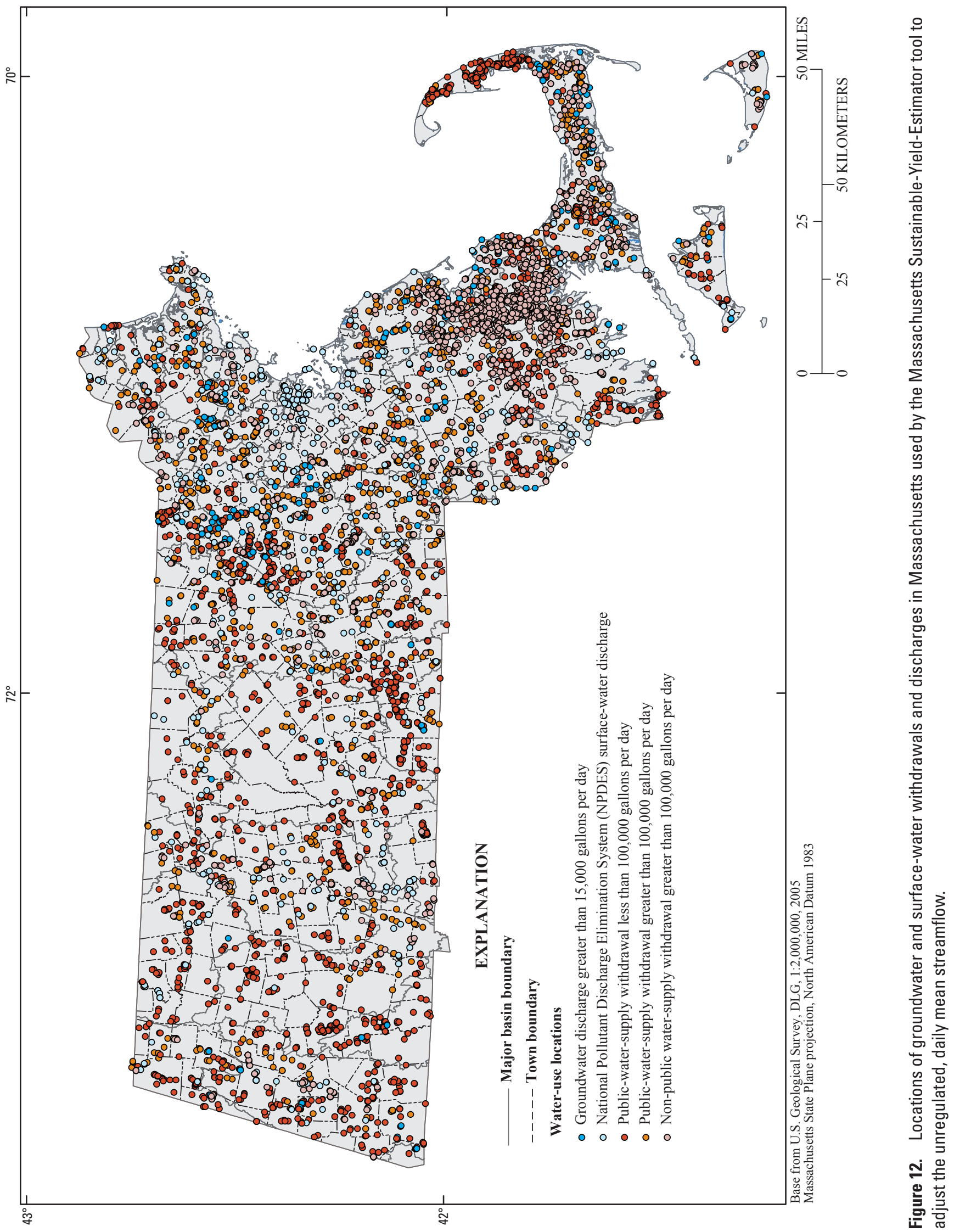


Table 7. Water-use type, number of sites, reporting units and statistics, and time and spatial resolution of water withdrawal and discharge sites in the statewide water-use database used with the Massachusetts Sustainable-Yield-Estimator tool to adjust daily, unregulated streamflow at ungaged sites in Massachusetts.

[*, volumes are reported for either the source of the water or as a sum of volumes from aggregated withdrawal sources]

\begin{tabular}{|c|c|c|c|c|c|}
\hline Water-use type & $\begin{array}{l}\text { Number } \\
\text { of sites in } \\
\text { statewide } \\
\text { database }\end{array}$ & Reporting units & Reported statistic & $\begin{array}{l}\text { Time } \\
\text { resolution } \\
\text { of reported } \\
\text { data }\end{array}$ & Resolution of reported data* \\
\hline $\begin{array}{l}\text { Public-water-supply withdrawal } \\
\text { less than 100,000 gallons per } \\
\text { day }\end{array}$ & 2,361 & $\begin{array}{l}\text { Million gallons } \\
\text { per year }\end{array}$ & Annual total & Annual data & $\begin{array}{l}\text { Withdrawal volumes reported for } \\
\text { water source }\end{array}$ \\
\hline $\begin{array}{l}\text { Public-water-supply withdrawal } \\
\text { greater than 100,000 gallons } \\
\text { per day }\end{array}$ & 1,420 & $\begin{array}{l}\text { Million gallons } \\
\text { per year }\end{array}$ & Annual total & Annual data & $\begin{array}{l}\text { Withdrawal volumes reported for } \\
\text { water source }\end{array}$ \\
\hline $\begin{array}{l}\text { Non-public water-supply } \\
\text { withdrawal greater than } \\
100,000 \text { gallons per day }\end{array}$ & 715 & $\begin{array}{l}\text { Million gallons } \\
\text { per day }\end{array}$ & Daily volume & Annual data & $\begin{array}{l}\text { Withdrawal volumes reported } \\
\text { as sum of volumes from } \\
\text { aggregated withdrawal sources }\end{array}$ \\
\hline $\begin{array}{l}\text { Non-public water-supply } \\
\text { withdrawal greater than } \\
100,000 \text { gallons per day used } \\
\text { for cranberry production }\end{array}$ & 1,028 & $\begin{array}{l}\text { Area cultivated, } \\
\text { in square } \\
\text { miles }\end{array}$ & Acres & Annual data & $\begin{array}{l}\text { Withdrawal volumes reported } \\
\text { as sum of volumes from } \\
\text { aggregated withdrawal sources }\end{array}$ \\
\hline $\begin{array}{l}\text { Ground-water discharge greater } \\
\text { than } 10,000 \text { gallons per day }\end{array}$ & 204 & Gallons per day & $\begin{array}{l}\text { Maximum daily } \\
\text { discharge }\end{array}$ & Monthly data & $\begin{array}{l}\text { Withdrawal volumes reported for } \\
\text { water source }\end{array}$ \\
\hline $\begin{array}{l}\text { National Pollutant Discharge } \\
\text { Elimination System (NPDES) } \\
\text { surface-water discharge }\end{array}$ & 854 & $\begin{array}{l}\text { Million gallons } \\
\text { per day or } \\
\text { gallons per } \\
\text { day }\end{array}$ & $\begin{array}{l}\text { Annual average, } \\
\text { 30-day average, } \\
\text { monthly average, } \\
\text { daily average, } \\
\text { rolling average, } \\
\text { weekly average }\end{array}$ & Monthly data & $\begin{array}{l}\text { Withdrawal volumes reported for } \\
\text { water source }\end{array}$ \\
\hline
\end{tabular}

\section{Disaggregation of Withdrawal and Discharge Volumes}

The MA SYE tool adjusts the unregulated, daily mean streamflow using the permitted groundwater and surface-water withdrawals in the statewide database; however, the resolution and quality of the reported data are not uniform (table 7), and daily withdrawal and discharge volumes are not reported. Therefore, withdrawal and discharge volumes must first be disaggregated to daily values before the unregulated, daily mean streamflow can be adjusted. In the MA SYE tool, data reported in the spatially referenced database can be overridden and replaced by more detailed information or by hypothetical withdrawal and discharge volumes.
Groundwater and surface-water discharge volumes are recorded monthly in the statewide database. To obtain daily discharge values, the monthly volumes are divided by the number of days in each respective month, which results in constant daily discharge values over each month.

Groundwater and surface-water withdrawals are reported annually in the statewide database. Annual volumes are disaggregated to monthly values using one of three monthly withdrawal patterns. For non-public-water-supply withdrawals, volumes are disaggregated from annual to monthly values using a constant monthly withdrawal pattern. Daily volumes are computed by dividing the monthly volumes by the number of days in each respective month. For public-water-supply withdrawals, separate monthly withdrawal patterns are used 
for groundwater and surface-water withdrawals. These patterns were computed using a sample of towns across Massachusetts that had source-level electronically available monthly volumes (table 8). Selected towns had either all groundwater (25 towns) or all surface-water ( 6 towns) withdrawal volumes for the periods shown in table 8. Monthly volumes for a town were divided by the total annual withdrawal volume to obtain the fraction of annual water withdrawal from the groundwater or surface-water sources in each month. For towns with groundwater withdrawals, average monthly fractions vary between the summer and winter months (fig. 13A). For towns with surface-water withdrawals, average monthly fractions do not vary substantially, even in the summer months (fig. 13B). The demand curves used in the MA SYE tool are the median values of the monthly demand fractions in each month (fig. 13). After disaggregating withdrawal volumes to monthly volumes using one of the three characteristic demand patterns, the MA SYE computes daily water-use values from the monthly values by dividing the monthly volumes by the number of days in each respective month.

\section{Use of the STRMDEPL Program}

Several assumptions are made about the withdrawal and discharge volumes when using the MA SYE tool, including a steady-state condition between a groundwater withdrawal or discharge and streamflow. For the steady-state condition,

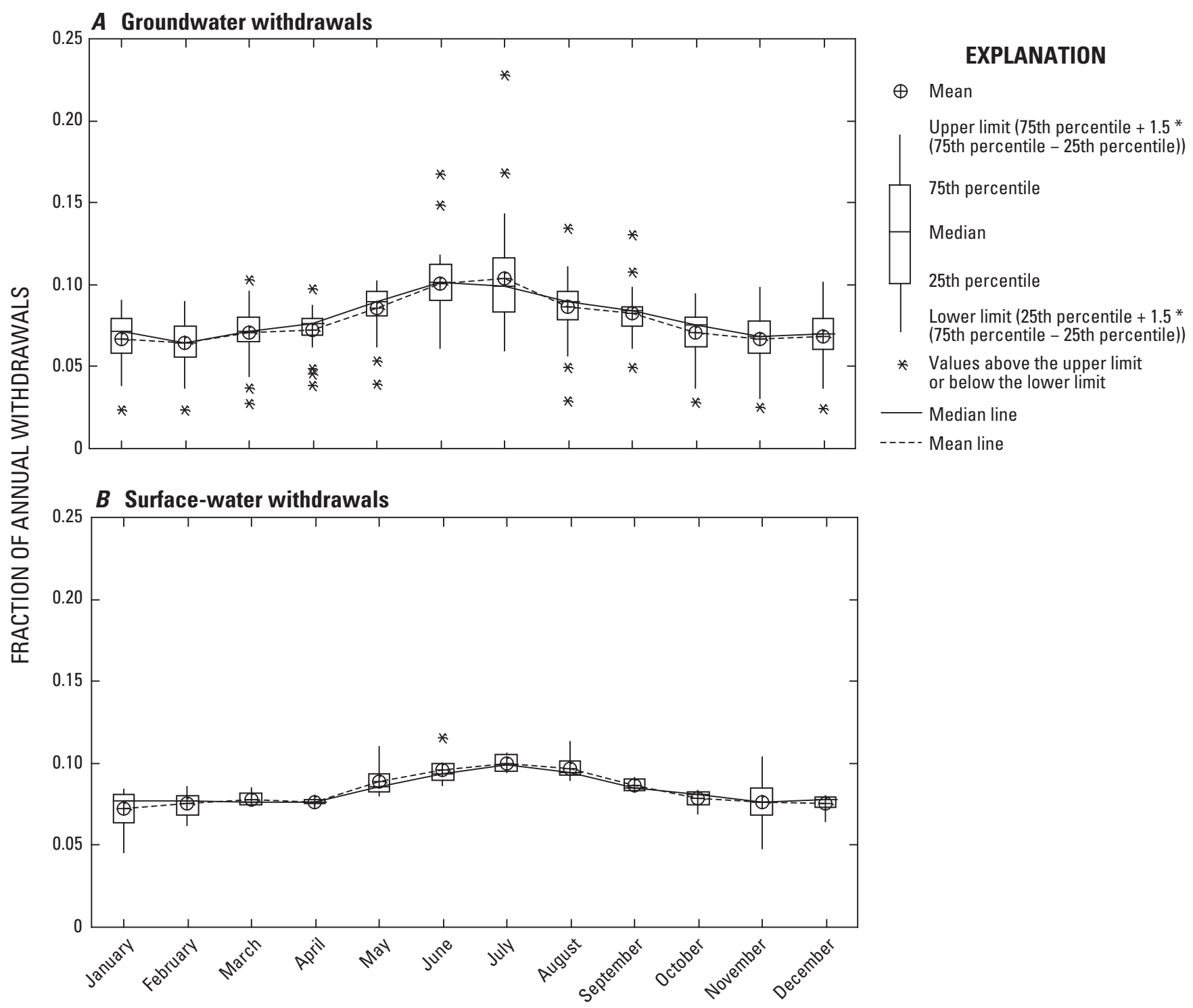

Figure 13. Distribution of the monthly fraction of the total annual withdrawal volumes for (A) groundwater and (B) surface-water public-water-supply withdrawals in Massachusetts. 
Table 8. Source of water withdrawals, towns, and years of monthly data used to determine characteristic demand curves for public water supply groundwater and surface-water withdrawals in Massachusetts.

\begin{tabular}{|c|c|c|}
\hline $\begin{array}{c}\text { Source of water } \\
\text { withdrawal }\end{array}$ & Town & $\begin{array}{c}\text { Years of } \\
\text { monthly data }\end{array}$ \\
\hline \multirow[t]{6}{*}{ Surface water } & Ashburnham & $1993-2000$ \\
\hline & Gardner & 1993-2000 \\
\hline & Lynnfield & 1994-1999 \\
\hline & Wakefield & 1994-1999 \\
\hline & Winchendon & 1996-2003 \\
\hline & Worcester & 1996-2001 \\
\hline \multirow[t]{25}{*}{ Groundwater } & Acton & 2000-2004 \\
\hline & Auburn & 1996-2001 \\
\hline & Bellingham & 1996-2001 \\
\hline & Blackstone & 1996-2003 \\
\hline & Boylston & $1996-2001$ \\
\hline & Byfield & 1993-2001 \\
\hline & Douglas & 1996-2001 \\
\hline & Georgetown & 1990-2001 \\
\hline & Grafton & 1996-2001 \\
\hline & Hopedale & 1996-2001 \\
\hline & Hopkinton & 1996-1999 \\
\hline & Mendon & $1996-2001$ \\
\hline & Millbury & 1996-2001 \\
\hline & Millville & 1996-2001 \\
\hline & Natick & 1996-2003 \\
\hline & North Attleboro & 1996-2001 \\
\hline & Northbridge & 1996-2001 \\
\hline & Rowley & $1995-2000$ \\
\hline & Shrewsbury & 1996-2001 \\
\hline & Sutton & 1996-2001 \\
\hline & Templeton & $1993-2000$ \\
\hline & Upton & 1996-2001 \\
\hline & Uxbridge & 1993-1998 \\
\hline & Whitinsville & 1998-2001 \\
\hline & Wrentham & 1996-2001 \\
\hline
\end{tabular}

it is assumed that there are no time-lag effects of groundwater withdrawals or discharges on streamflow. For some groundwater withdrawal and discharge locations, this may be a reasonable assumption; however, for other groundwater withdrawal and discharge locations this assumption may not hold.

To account for time-lag effects, users have the option of applying the program STMDEPL (Barlow, 2000) to account for the effects of the aquifer on streamflow depletion or augmentation. The STMDEPL program requires three parameters: (1) the transmissivity of the aquifer, $T$, in units of square length per time, (2) the storativity of the aquifer, $S$, a dimensionless quantity, and (3) the distance between the withdrawal or discharge location and the nearest surface-water body within the same basin, in length units. As input to the STRMDEPL program, the transmissivity $(T)$ and storativity $(S)$ are combined and entered as a single parameter, known as diffusivity $(S / T)$.

For the purposes of the MA SYE, it was not practical to assign diffusivity values to each of the 4,250 groundwater withdrawal and discharge locations because of the time and effort involved, and because, for many locations, the diffusivity value is unknown. Furthermore, time-lag effects are likely to be negligible for groundwater withdrawals and discharges located in close proximity to a surface-water body; therefore, populating diffusivity values for these locations would not be useful. To understand the relation between proximity and time-lag effects on streamflow, a simple sensitivity experiment using STRMDEPL was performed. STRMDEPL was used to simulate the streamflow depletion for a broad range of diffusivities and distances between a hypothetical groundwater-withdrawal location and the nearest surface-water body (fig. 14). For distances less than 250 feet, streamflow depletion is about equal to the withdrawal rate from the well, and the time-lag effects of the withdrawal on streamflow are negligible (fig. 14).

Diffusivity values are not available in the statewide database, but distances between groundwater withdrawal and discharge locations and the nearest surface-water body are provided in the MA SYE tool. Approximately one-half of the groundwater withdrawal and discharge locations in the statewide database are within 250 feet of the nearest surfacewater body. The ArcHydro raindrop tool (Maidment, 2002) was used to identify the nearest surface-water body (stream or lake) within the contributing basin. The raindrop tool traces the surface path of a drop of water on the landscape to the receiving surface-water body. Once the nearest surface-water body was identified, the perpendicular distance between the withdrawal or discharge location and the surface-water body was computed. Distances between groundwater discharge or withdrawal sources and the nearest surface-water body have been pre-calculated for 3,029 locations, and these distances are stored in the spatially referenced database. 


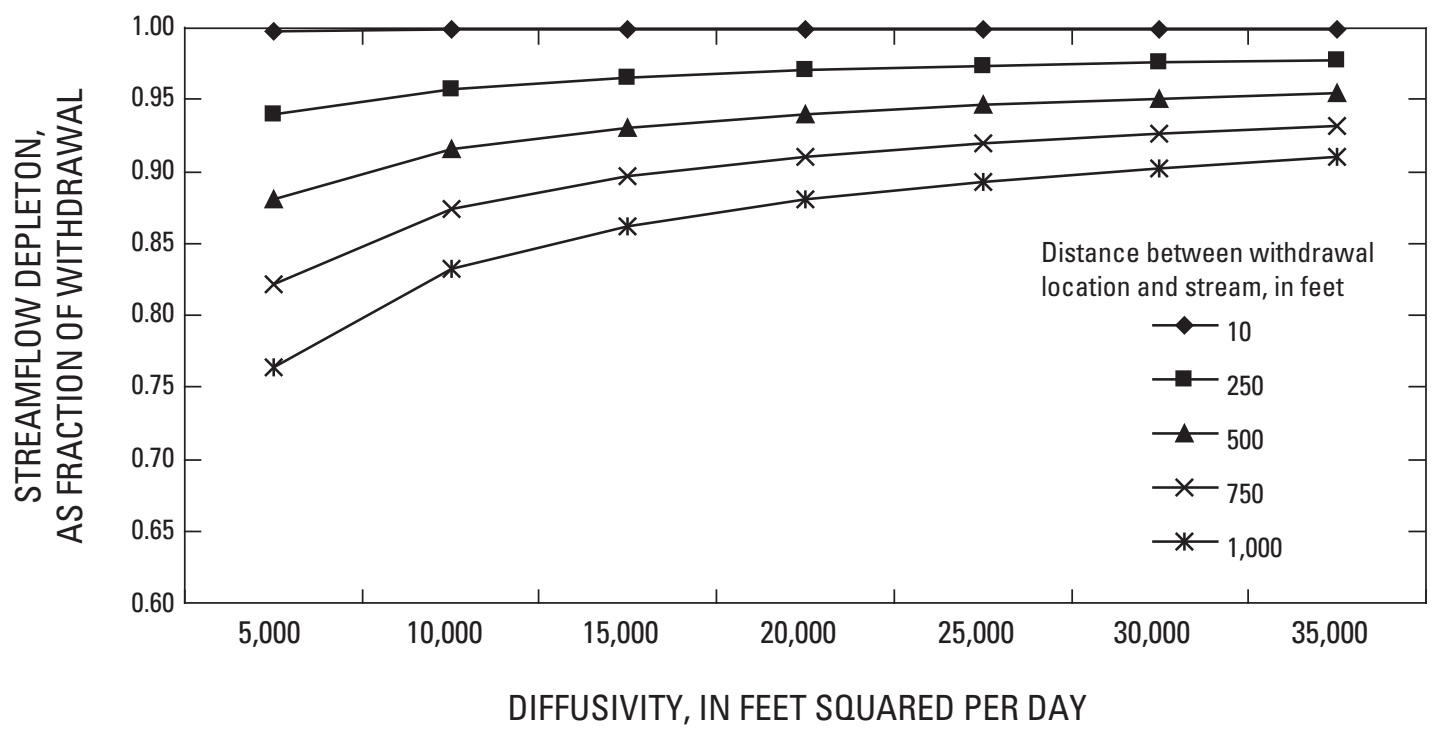

Figure 14. Streamflow depletion estimated by the STRMDEPL program for a range of diffusivity values and distances between a hypothetical withdrawal location and stream (STRMDEPL program from Barlow, 2000).

\section{Estimation of Streamflow when Groundwater and Surface-Water Divides are not Coincident}

It is assumed when using the MA SYE tool that the contributing basin to the user-selected stream location has coincident groundwater and surface-water divides. This assumption is true for a large portion of Massachusetts; however, for many areas in southeastern Massachusetts, groundwater and surfacewater divides differ. For these areas, existing, calibrated groundwater-flow models (Masterson and others, 2009; Walter and others, 2004; Walter and Whelan, 2004) were used to simulate average monthly streamflows at fixed locations near the mouths of major streams (fig. 15). For each fixed location, withdrawals and discharges in the groundwater-flow model were removed to simulate unregulated, average monthly streamflow. A second set of average monthly streamflows also was simulated using present day (as specified in the respective reports) withdrawal and discharge volumes. In the MA SYE tool, users can select from one of the fixed stream locations in these areas for calculation of sustainable yield. Results are served to the user through the MA SYE tool user interface, as described in the MA SYE user's manual located at http://pubs.usgs.gov/sir/2009/5227/.

\section{Calculation of Sustainable Yields Using the Massachusetts Sustainable- Yield Estimator (MA SYE) Tool}

The MA SYE tool provides estimates of unregulated, daily mean streamflow and adjusted daily streamflows for groundwater and surface-water withdrawals and discharges. Users can quickly and easily compute the screening-level values of sustainable yield by specifying time-varying flow targets (the quantities of water to be left in the stream). The flow targets can be entered as monthly user-specified values in cubic feet per second, cubic feet per second per mile, or daily percentage of the unregulated streamflows to remain in the stream. These flow targets are then subtracted from the unregulated, daily streamflow to provide an estimate of the sustainable yield for the contributing basin at the location on the stream of interest. Calculations are based not only on userspecified flow targets but also on a user-specified time period between 1960 and 2004.

Users can also adjust the unregulated, daily mean streamflow by subtracting and adding the reported groundwater and surface-water withdrawal and discharge volumes, respectively. The user can adjust each selected year of unregulated, daily mean streamflow by the withdrawal and discharge volumes 


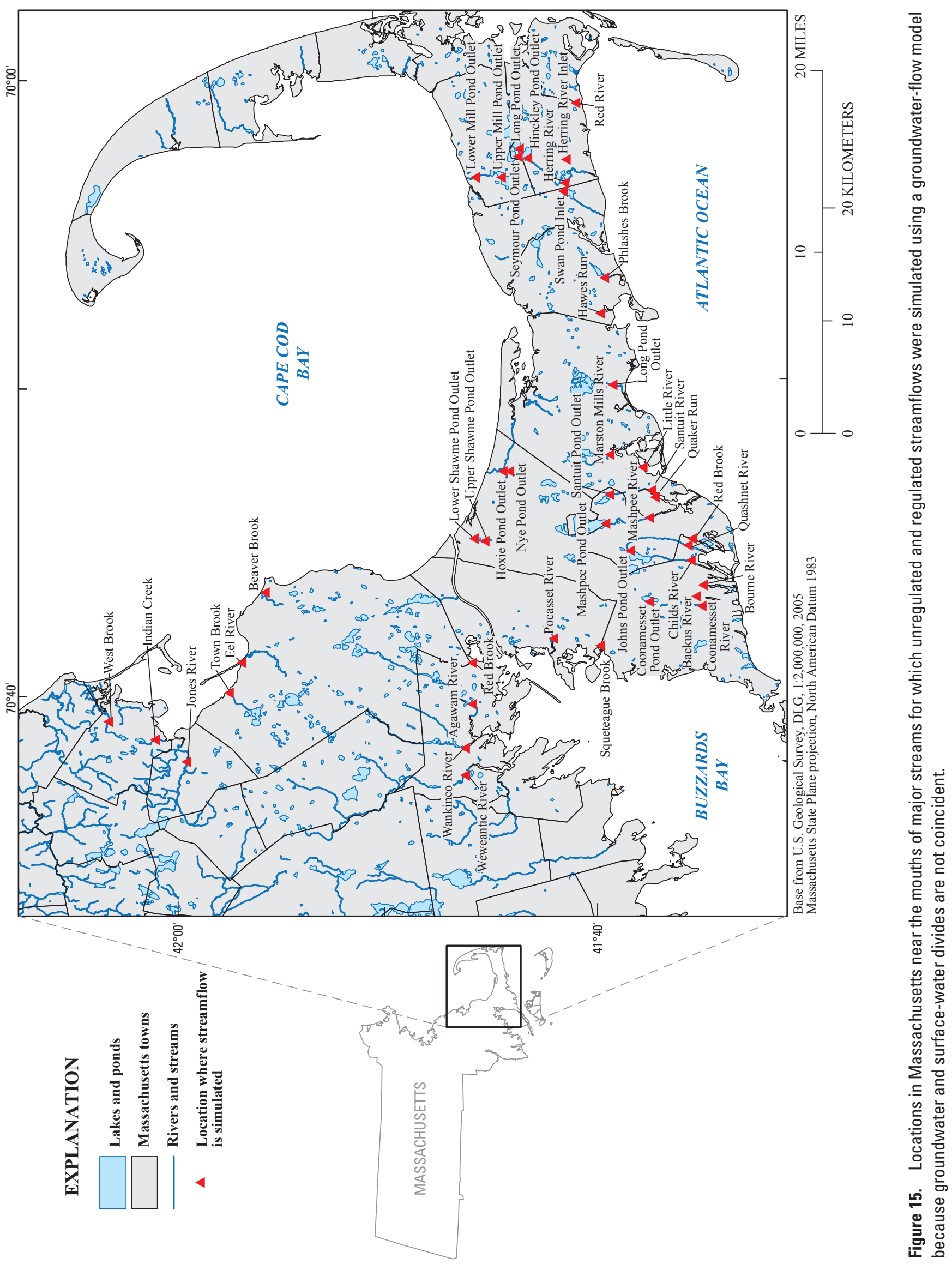


reported for a particular year from 2000 through 2004 or by an average year. Results of the unregulated and adjusted streamflows, as well as the user-specified flow targets, are summarized on a two-page report that graphically displays the unregulated and adjusted streamflows along with the flow targets for the user-specified time period. Average, monthly unregulated streamflow values are calculated and compared to the flow targets. General information about the calculation of the unregulated and adjusted streamflows also is provided in the summary report, such as the physical and climate basin characteristics, reference streamgage used to compute the unregulated streamflows, and the number of withdrawal and discharge locations in the basin.

The MA SYE tool was designed as a desktop application that employs the Environmental Systems Research Institute, Inc. (ESRI) ArcMap GIS software (Environmental Systems Research Institute, Inc., 2009) coupled with Microsoft Excel and Access, commonly used and widely available spreadsheet and database programs, respectively. Available options are

- Select the period of analysis,

- Select an average or single year of withdrawal and discharge volumes to adjust the unregulated streamflow,

- Select a different reference streamgage,

- Edit withdrawal and discharge volumes for any wateruse point within the basin,

- Apply STRMDEPL (Barlow, 2000) to a groundwater withdrawal or discharge volume,

- Add or edit aquifer properties used in the computation of streamflow depletion,

- Add a volume or percent of total withdrawals returned to the basin from septic-system discharge,

- Enter custom flow targets or choose from a predefined list of targets, and

- Export results to text files compatible with the Indicators of Hydrologic Alteration (IHA) (The Nature Conservancy, 2005) tool and the National Hydrologic Assessment Tool (NAHAT) (Hendrickson and others, 2006), which allow for the computation of over 151 streamflow statistics. Unregulated and adjusted streamflows can be readily output to these programs for a comparison of a wide variety of flow statistics.

Once a user selects the location on a stream of interest from the MA SYE GIS user interface, a spreadsheet template guides the user through the remaining functions of the MA SYE tool. All related files needed to use the MA SYE along with a complete user's manual with installation instructions for the MA SYE tool is available at http://pubs.usgs.gov/sir/2009/5227/.

\section{Limitations}

There are several limitations to the use of the MA SYE tool for estimating unregulated, daily mean streamflow time series. In particular, the use of the regression equations is limited to the range of basin characteristics used to develop the regression equations (fig. 5). The MA SYE tool provides warnings for all basin characteristics with values outside the range for which the regression equations were developed. Spatial correlation between streamflows could be accommodated through a generalized least-squares approach, but that is beyond the scope of this report. Prediction and confidence intervals associated with estimates of unregulated, daily mean streamflows could be used to make comparisons using existing methods to estimate unregulated streamflow at ungaged sites or to determine whether significant differences exist between estimated unregulated and regulated streamflows. The three components - (1) regression equations, (2) reference-streamgage selection criteria, and (3) the assumption of equivalent exceedence probabilities on the same day-all contribute to the uncertainty associated with MA SYE estimates of unregulated, daily mean streamflows; however, there does not currently exist a theoretical framework from which prediction or confidence intervals for the MA SYE-estimated daily streamflows can be derived. A lack of theoretical framework for error documentation also limits the understanding of, and ability to model, the unregulated, daily mean FDC.

Estimates of adjusted, daily mean streamflow have several important limitations. Adjusted streamflow estimates consider only withdrawal and discharge locations that are part of the statewide water-use database. Limitations of the quality and resolution of the statewide database affect the estimates of adjusted streamflow. The use of a constant daily withdrawal pattern for non-public-water-supply withdrawal volumes does not take into account the seasonal withdrawals, such as golf course watering, which will lead to underestimation of the effects of withdrawals during the summer low-flow period. The MA SYE tool addresses these data quality and resolution limitations by allowing the user to override reported withdrawal and discharge volumes in the statewide database and provide more detailed information.

A change in withdrawal or discharge volumes at one location may have an affect on withdrawal or discharge volumes at other locations in the basin. For example, an increase in a withdrawal volume at one location might result in increases in the discharge volume at other locations within the basin. Additionally, if monthly data are redistributed within a particular year, no warnings are provided if the new annual total dischage or withdrawal volume differs from the annual volume reported in the MA SYE water-use database.

Adjusted streamflow estimates do not account for the effects of impoundments; septic-system discharge; private domestic withdrawals; non-public-water-supply withdrawals of less than 100,000 gallons per day; and impervious area, 
which can affect streamflow. To address the limitation of septic-system discharge, the MA SYE allows the user to enter a percentage of total withdrawals that is returned to the basin or a volume that is added to the adjusted streamflow. Withdrawals from surface-water reservoirs are directly subtracted from the unregulated streamflows, and the storage effects of reservoirs are not included in the adjusted-streamflow estimates. Users have the option of removing surface-water reservoirs from the adjusted-streamflow calculations by choosing to ignore the withdrawal location, which entirely removes the effects of these withdrawals on the adjusted-streamflow values.

The MA SYE tool does not contain data on withdrawal and discharge volumes for locations outside of Massachusetts. Therefore, if a user-selected point on a stream has a contributing area outside of Massachusetts, the MA SYE tool warns the user that the adjusted streamflows will not include the withdrawal and discharge volumes located outside of Massachusetts. An updated version of STRMDEPL, termed "STMDEPL08" (Reeves, 2008) has been developed to address some of the simplifying assumptions in STRMDEPL; however STMDEPL08 has not been incorporated into the MA SYE tool.

The MA SYE tool is unable to estimate streamflow for locations on the main stems of the Connecticut and Merrimack Rivers because large portions of these drainage basins are outside of Massachusetts and the methods developed for the MA SYE tool do include streamgages or basin characteristics for the northern portions of these basins. Furthermore, basin characteristics for these basins cannot presently be summarized in a consistent manner and are outside the scope of the MA SYE tool. If a user clicks on the main stems of the Connecticut and Merrimack Rivers, the MA SYE tool delineates a drainage basin but displays a message that the MA SYE tool is unable to continue.

\section{Summary}

To quantify the sustainable yield of a basin - the unregulated, daily mean streamflow less some user-specified flow targets-at ungaged sites in Massachusetts, the U.S. Geological Survey, in cooperation with the Massachusetts Department of Environmental Protection (MassDEP), developed the Massachusetts Sustainable-Yield-Estimator (MA SYE) tool. The MA SYE tool is designed to be a flexible, statewide, screeninglevel decision-support system to compute the sustainable yield of a basin and to evaluate the effects of water withdrawals and discharges on streamflow. The MA SYE tool estimates both the unregulated, daily mean streamflow and streamflow adjusted for water withdrawals and discharges within the basin for a user-selected location on a stream in Massachusetts.

The MA SYE tool estimates an unregulated, daily mean time series of streamflow for a 44-year period (October 1, 1960, through September 30, 2004) using statistically based methods. First, streamflow quantiles are calculated at six exceedence probabilities by regressing streamflow against readily measureable climate and physical basin characteristics. Next streamflow quantiles at 11 additional exceedence probabilities are solved by use of regression to quantify the structure of the streamflow quantiles. A continuous daily flowduration curve (FDC) at the ungaged site is then obtained by log-linear interpolation among the 17 regression-estimated streamflow quantiles. Lastly, a reference streamgage is used to transform the FDC into daily mean streamflow. The reference streamgage is determined from the estimated correlation of the logarithms of the daily streamflows between the ungaged location and one of 66 potential reference streamgages.

The MA SYE tool estimates an adjusted daily mean time series of streamflow at ungaged sites from reported withdrawal and discharge volumes at locations within the basin. Withdrawal and discharge volumes used in the MA SYE tool are obtained from a spatially referenced statewide database of groundwater and surface-water withdrawals, groundwater discharges, and National Pollutant Discharge Elimination System (NPDES) surface-water discharges. For a user-selected basin, groundwater and surface-water withdrawal and discharge volumes are subtracted and added, respectively, from the unregulated, daily streamflow. Time-varying groundwater withdrawals and discharges can be optionally modified using an analytical program, STRMDEPL, which simulates the effects of the aquifer properties on the timing and magnitude of streamflow alteration.

For the MA SYE tool, it is necessary that groundwater and surface-water divides are coincident for the contributing basin; however, in southeastern Massachusetts and Cape Cod, groundwater-flow models have shown that the surface and subsurface divides differ. In the MA SYE tool, streamflows are obtained from existing groundwater-flow model simulations for these areas, which computed streamflows with and without inclusion of the groundwater and surface-water withdrawals in the model simulations. For the MA SYE tool, it is assumed that groundwater and surface-water divides are coincident for all other areas in Massachusetts.

The user interface of the MA SYE tool was designed as a desktop application that employs Environmental Systems Research Institute, Inc. ArcMap software, a geographic information system, coupled with Microsoft Excel and Access. On the basis of user-defined constraints such as existing water withdrawals and discharges in the basin and flow targets, the MA SYE tool estimates the sustainable yield of the basin by subtracting the flow targets from the unregulated, daily mean streamflow. The MA SYE tool supplies the user with graphical and numerical comparisons of the unregulated and adjusted streamflows relative to any user-specified flow targets. Users can compute the water availability in the basin for any number of water-management scenarios (by changing the withdrawal and discharge volumes, the time period of analysis, or flow targets). Results of each water-management scenario are summarized in a two-page report that displays the unregulated and adjusted streamflow hydrographs for the user-specified time 
period and presents selected streamflow statistics calculated from these hydrographs in tabular format.

\section{Acknowledgments}

The authors thank Paul Blain, Thomas Lamonte, Kari Winfield, and Robert Hames of the Massachusetts Department of Environmental Protection for their reviews of the report and decision-support tool and Phillip Zarriello, David Armstrong, and Gardner Bent of the U.S. Geological Survey for their participation in the technical reviews of the project. The authors also thank Jery Stedinger of Cornell University for providing technical insights on the estimation of streamflow at ungaged sites; Amy Lavoie of the U.S. Environmental Protection Agency for providing insights into the way withdrawals vary temporally and spatially across Massachusetts; Leslie DeSimone, John Masterson, and Jeff Barbaro of the U.S. Geological Survey for providing detailed water-use data; Mark Smith and Colin Apse of The Nature Conservancy for their helpful comments related to the decision-support tool; and Nigel Pickering of the Charles River Watershed Association and Christian Jacques at MassGIS for initiating the development of, and contributions to, a statewide database of permitted groundwater and surface-water withdrawals and discharges in Massachusetts.

\section{References Cited}

Agresti, A., 1990, Categorical Data Analysis: New York, John Wiley \& Sons, $734 \mathrm{p}$.

Alley, W.M., and Leake, S.A., 2004, The journey from safe yield to sustainability: Ground Water, v. 42 , no. 1 , p. 12-16.

Archfield, S.A., 2009, Estimation of streamflow at ungaged sites in southern New England: Medford, MA, Tufts University, Ph.D. dissertation, p. or unpublished Ph.D. dissertation.

Armstrong, D.S., Parker, G.W., and Richards, T.A., 2008, Characteristics and classification of least altered streamflows in Massachusetts: U.S. Geological Survey Scientific Investigations Report 2007-5291, 113 p., plus CD-ROM.

Barbaro, J.R., 2007, Simulation of the effects of water withdrawals, wastewater-return flows, and land-use change on streamflow in the Blackstone River Basin, Massachusetts and Rhode Island: U.S. Geological Survey Scientific Investigations Report 2007-5183, 98 p.

Barbaro, J.R., and Zarriello, P.J., 2006, A precipitation-runoff model for the Blackstone River Basin, Massachusetts and Rhode Island: U.S. Geological Survey Scientific Investigations Report 2006-5213, 95 p.
Barlow, P.M., 2000, Documentation of computer program STRMDEPL-A program to calculate streamflow depletion by wells using analytical solutions, in Zarriello, P.J., and Ries, K.G., III, A Precipitation Runoff Model for Analysis of the Effects of Water Withdrawals on Streamflow, Ipswich River Basin, Massachusetts: U.S. Geological Survey Water Resources Investigations Report 00-4029, p. 77-89.

Black, A.R., Rowan, J.S., Duck, R.W., Bragg, O.M. and Clelland, B.E., 2005, DHRAM: a method for classifying river flow regime alterations for the EU Water Framework Directive: Aquatic Conservation: Marine \& Freshwater Ecosystems, v. 15 , p. 427-446.

DeSimone, L.A., 2004, Simulation of ground-water flow and evaluation of water-management alternatives in the Assabet River Basin, eastern Massachusetts: U.S. Geological Survey Scientific Investigations Report 2004-5114, 133 p.

DeSimone, L.A., Walter, D.A., Eggleston, J.R., and Nimroski, M.T., 2002, Simulation of groundwater flow and evaluation of water-management alternatives in the Upper Charles River Basin, eastern Massachusetts: U.S. Geological Survey Water-Resources Investigations Report 02-4234, 94 p.

Duan, N., 1983, Smearing estimate - a nonparametric retransformation method: Journal of the American Statistical Association, v. 78, no. 383, pp. 605-610.

Environmental Systems Research Institute, Inc., 2009, available at $h t t p: / / w w w . e s r i . c o m /$ accessed on August 4, 2009.

Fennessey, N.M., 1994, A hydro-climatological model of daily streamflow for the northeast United States: Medford, MA, Tufts University, Ph.D. dissertation, variously paged.

Fennessey, N.M. and Vogel, R.M., 1990, Regional flow duration curves for ungaged sites in Massachusetts: Journal of Water Resources Planning and Management, v. 116, no. 4, p. 530-549.

Helsel, D.R., and Hirsch, R.M., 1992, Studies in environmental science 49-Statistical methods in water resources: Amsterdam, Elsevier, 522 p.

Henriksen, J.A., Heasley, John, Kennen, J.G., and Nieswand, Steven, 2006, User's manual for the Hydroecological Integrity Assessment Process software: U.S. Geological Survey Open-File Report 2006-1093. 71 p., available online at http://www.fort.usgs.gov/products/ publications/21598/21598.pdf.

Hughes, D.A., and Smakhtin, V.U., 1996, Daily flow time series patching or extension: a spatial interpolation approach based on flow duration curves: Journal of Hydrological Sciences, v. 41, no. 6, p. 851-871.

Isaaks, E.H., and Srivastava, R.M., 1989, An Introduction to Applied Geostatistics: New York and Oxford, Oxford University Press, $561 \mathrm{p}$. 
Maidment, D., 2002, ArcHydro: GIS for Water Resources: Redlands, CA, Environmental Systems Research Institute, Inc., variously paged.

Maimone, M., 2004, Defining and managing sustainable yield: Ground Water, v. 42, no.6, November-December, p. 809-814.

Mahamoud, Y. M., 2008, Prediction of daily flow duration curves and streamflow for ungauged catchments using regional flow duration curves: Journal of Hydrological Sciences, v. 53, no. 4, p. 706-724.

Masterson, J.P., Carlson, C.S., Massey, A.J., and Walter, D.A., 2009, Hydrogeology and simulation of groundwater flow in Plymouth-Carver-Kingston-Duxbury aquifer system, southeastern Massachusetts: U.S. Geological Survey Scientific Investigations Report 2009-5063, 116 p.

McCullagh, P. and Nelder, J.A., 1983, Generalized Linear Models: London, Chapman Hall, 532 p.

Nash, J.E., and Sutcliffe, J. V., 1970, River flow forecasting through conceptual models part I-A discussion of principles: Journal of Hydrology, v. 10, no. 3, p. 282-290.

Poff, N.L., Allen, J.D., Bain, M.B., Karr, J.R., Prestagaard, K.L., Richter, B.D., Sparks, R.E., and Stromberg, J.C., 1997, The natural-flow regime-A paradigm for river conservation and restoration: Bioscience, v. 47, p. 769-784.

Reeves, H.W., 2008, STRMDEPL08-An extended version of STRMDEPL with additional analytical solutions to calculate streamflow depletion by nearby pumping wells: U.S. Geological Survey Open-File Report 2008-1166, 22 p.

Ries, K.G., and Friesz, P.J., 2000, Methods for estimating lowflow statistics for Massachusetts Streams: U.S. Geological Survey Water-Resources Investigations Report 2000-4135, $81 \mathrm{p}$.

Smakhtin, V.U., 1999, Generation of natural daily flow time series in regulated rivers using a non-linear spatial interpolation technique: Regulated Rivers: Research and Management, v. 15, p. 311-323.

Smakhtin, V.U. and Masse, B., 2000, Continuous daily hydrograph simulation using duration curves of a precipitation index: Hydrological Processes, v. 14, p. 1,083-1,100.

Soil Conservation Service (now Natural Resources Conservation Service), 1986, Urban hydrology for small watersheds: Washington, D.C., U.S. Department of Agriculture, Technical Release, 55 p.

Sophocleous, M., 2000, From safe yield to sustainable development of water resources - the Kansas experience: Journal of Hydrology, v. 23, no. 5, issues 1-2, p. 27-43.

Stedinger, J.R., Vogel, R.M., and Foufoula-Georgiou, E., 1993, Frequency analysis of extreme events, Chapter 18, in Maidment, D.R., ed., Handbook of Hydrology: New York, McGraw-Hill Book Company, p. 17.1-17.55.
Stedinger, J.R., Vogel, R.M., Lee, S.U., and Batchelder, R., 2008, Appraisal of generalized likelihood uncertainty estimation (GLUE) methodology: Water Resources Research, 44, WOOB06, doi:10.1029/2008WR006822, 2008.

U.S. Geological Survey, 2009, National StreamStats program, accessed January 12, 2008, at http://water.usgs.gov/osw/ streamstats/reference.html.

The Nature Conservancy, 2005, Indicators of hydrologic alteration, version 7, user's manual: The Nature Conservancy with Smythe Scientific Software and Totten Software Design, available online at $h t t p: / / w w w . n a t u r e . o r g / i n i t i a t i v e s /$ freshwater/files/ihav7.pdf.

Vogel, R.M., and Fennessey, N.M., 1994, Flow duration curves I: A new interpretation and confidence intervals: ASCE Journal of Water Resources Planning and Management, v. 120 , no. 4 , p. $485-504$.

Vogel, R.M., and Stedinger, J.R., 1985, Minimum variance streamflow record augmentation procedures: Water Resources Research, v. 21, no. 5, p. 715-723.

Vogel, R.M., Wilson, I., and Daly, C., 1999, Regional regression models of annual streamflow for the United States: Journal of Irrigation and Drainage Engineering, v. 125, no. 3, p. 148-157.

Waldron, M.C., and Archfield, S.A., 2006, Factors affecting firm yield and the estimation of firm yield for selected streamflow-dominated drinking-water-supply reservoirs in Massachusetts: U.S. Geological Survey Scientific Investigations Report 2006-5044, 39 p.

Walter, D.A., and LeBlanc, D.R., 2008, Use of inverse-modeling methods to improve ground-water-model calibration and evaluate model-prediction uncertainty, Camp Edwards, Cape Cod, Massachusetts: U.S. Geological Survey Scientific Investigations Report 2007-5257, 57 p.

Walter, D.A., Masterson, J.P., and Hess, K..M., 2004, Groundwater recharge areas to pumped wells, ponds, streams, and coastal water bodies, Cape Cod, Massachusetts: U.S. Geological Survey Scientific Investigations Map I-2857, 1 sheet.

Walter, D.A., and Whelan, A., 2004, Simulated water sources and effects of pumping on surface and ground water, Sagamore and Monomoy flow lenses, Cape Cod, Massachusetts: U.S. Geological Survey Scientific Investigations Report 2004-518185 p.

Zarriello, P.J. and Ries, K.G., 2000, A precipitation-runoff model for analysis of the effects of water withdrawals on streamflow, Ipswich River Basin, Massachusetts: U.S. Geological Survey Water Resources-Investigations Report 00-4029, $107 \mathrm{p}$. 


\section{Tables 1-2}




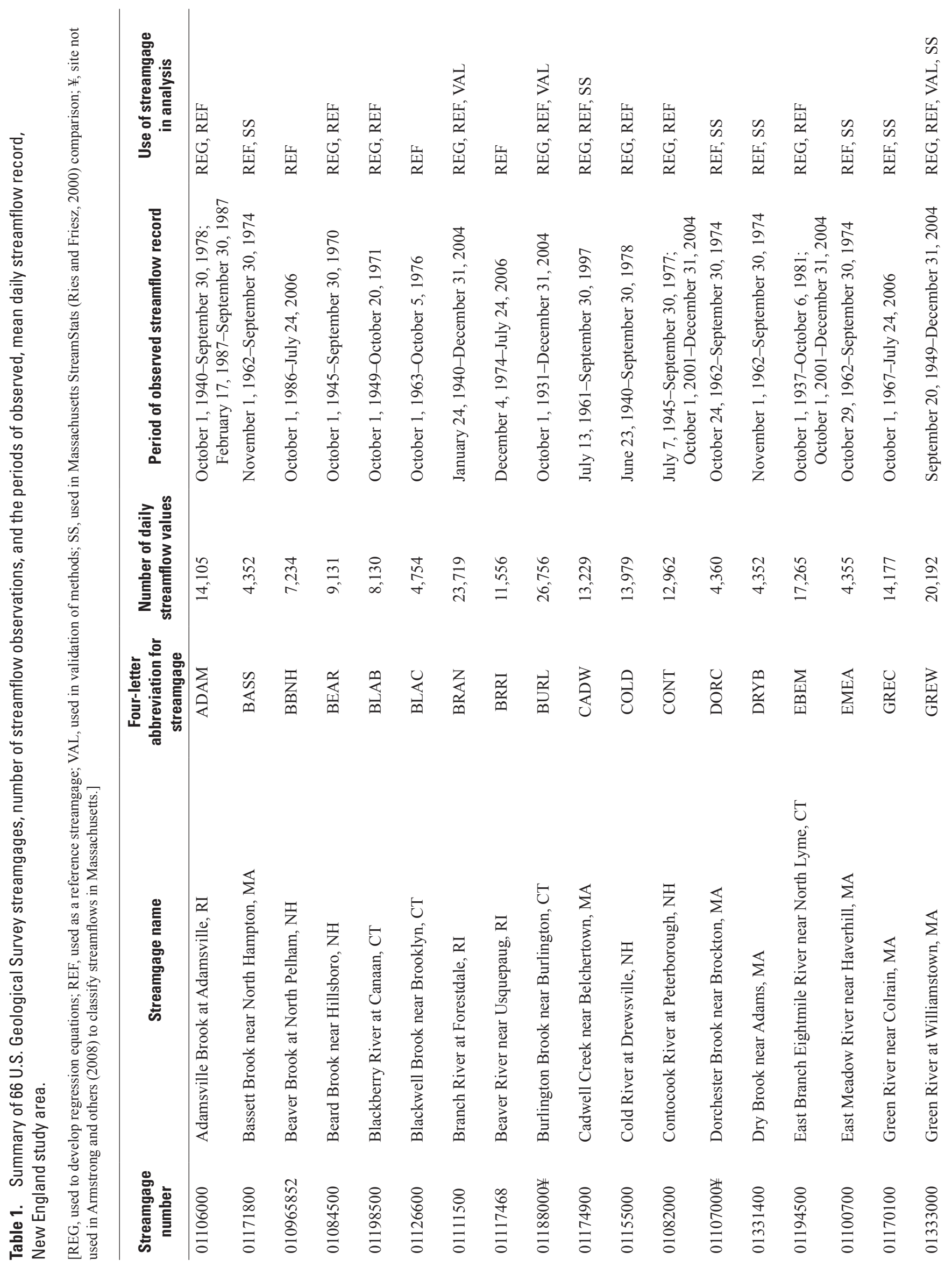




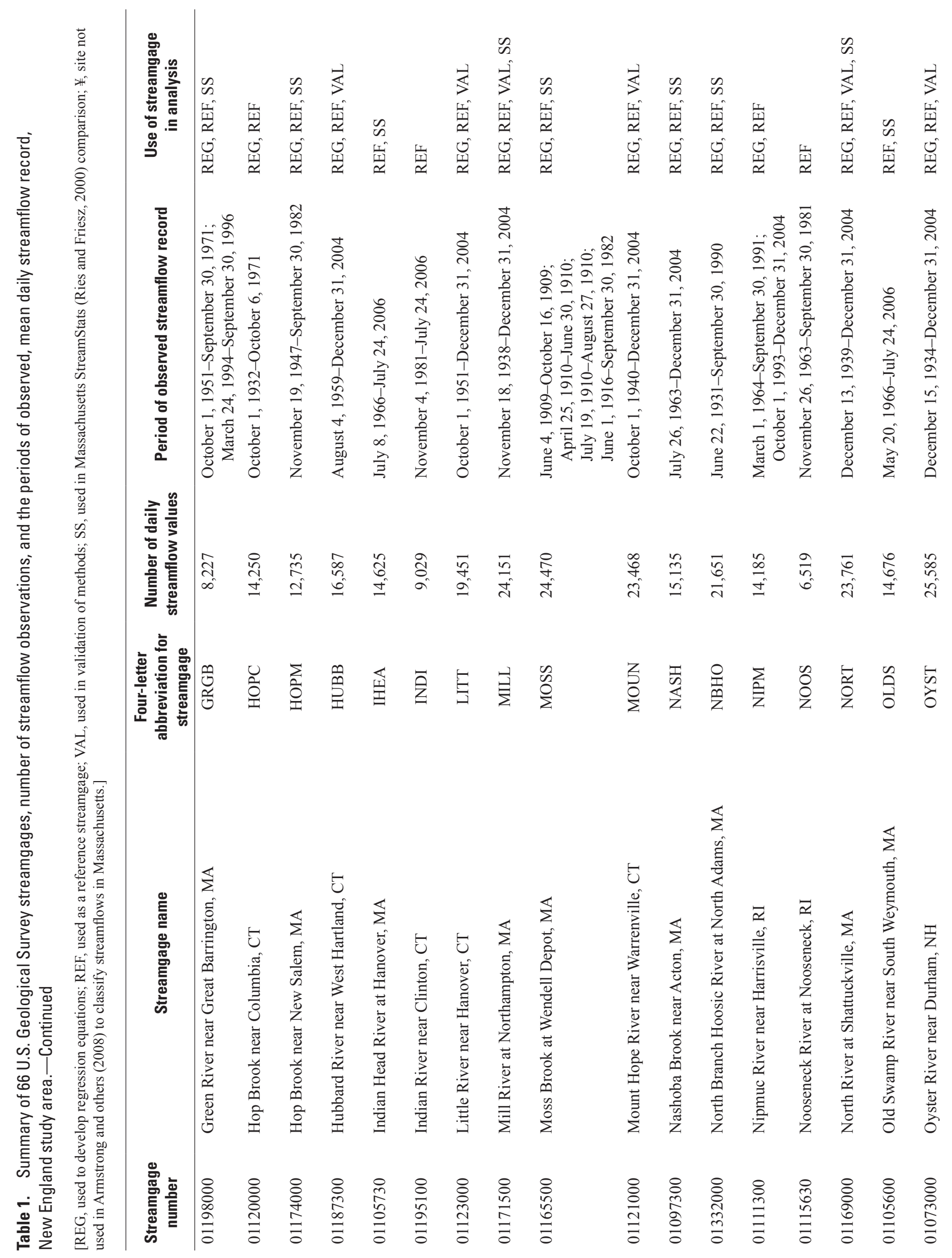




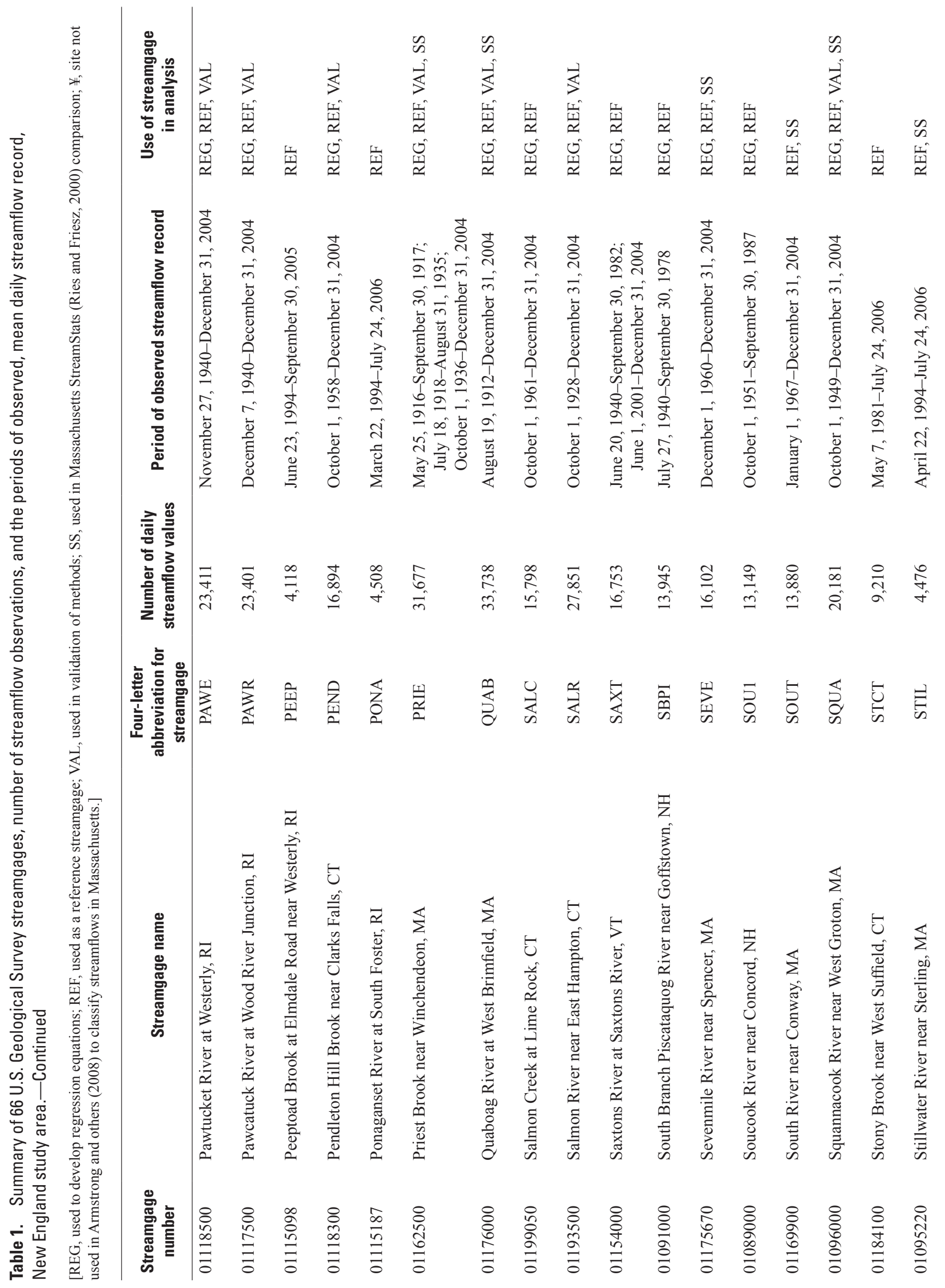


Table 1. Summary of 66 U.S. Geological Survey streamgages

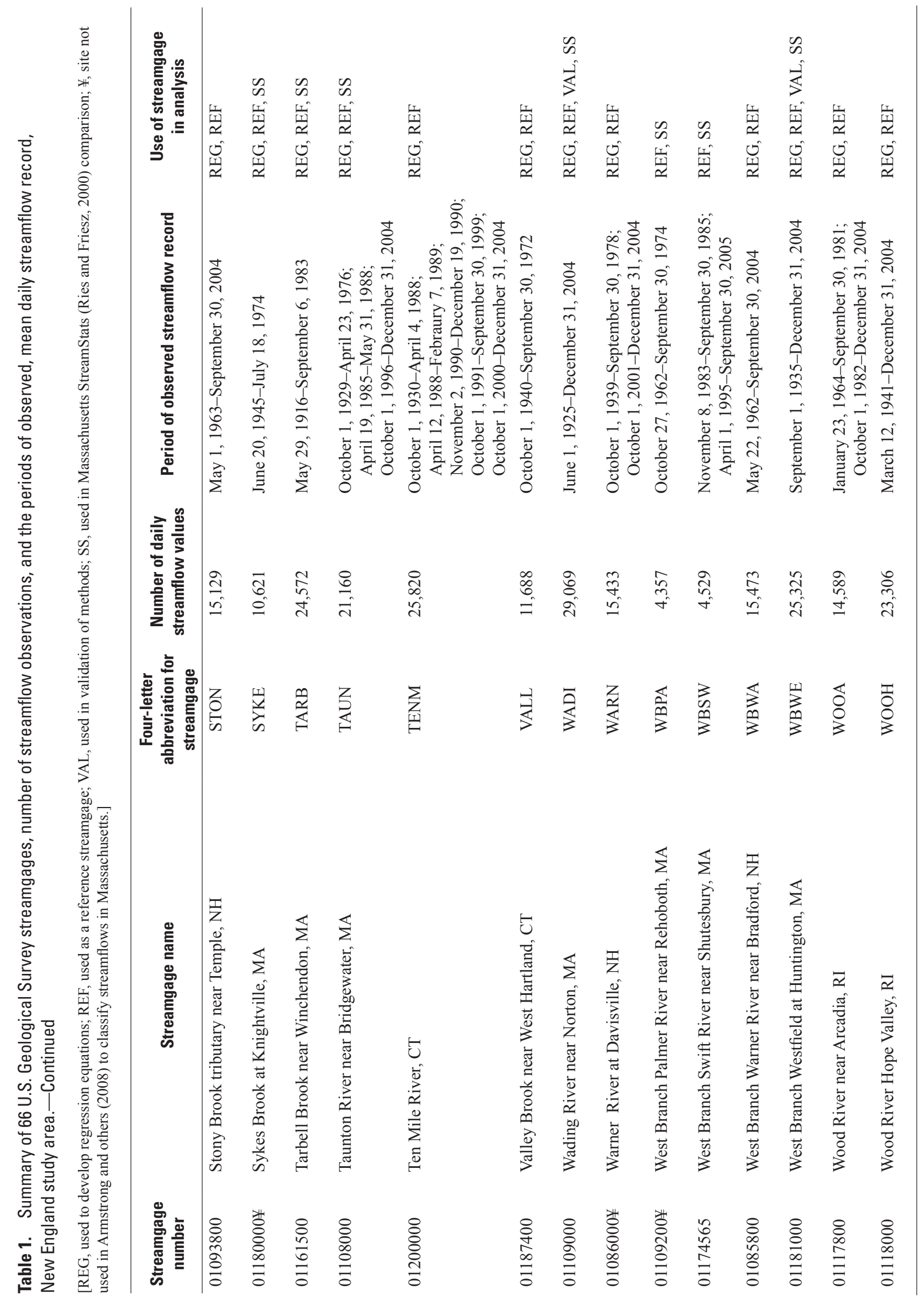


Table 2. Streamflow quantiles corresponding to 17 exceedence probabilities estimated from the observed period of record at 47 U.S. Geological Survey streamgages, New England study area.

[**, observed streamflow record does not contain enough observations to estimate; QX, streamflow value at the X divided by 100 exceedence probability]

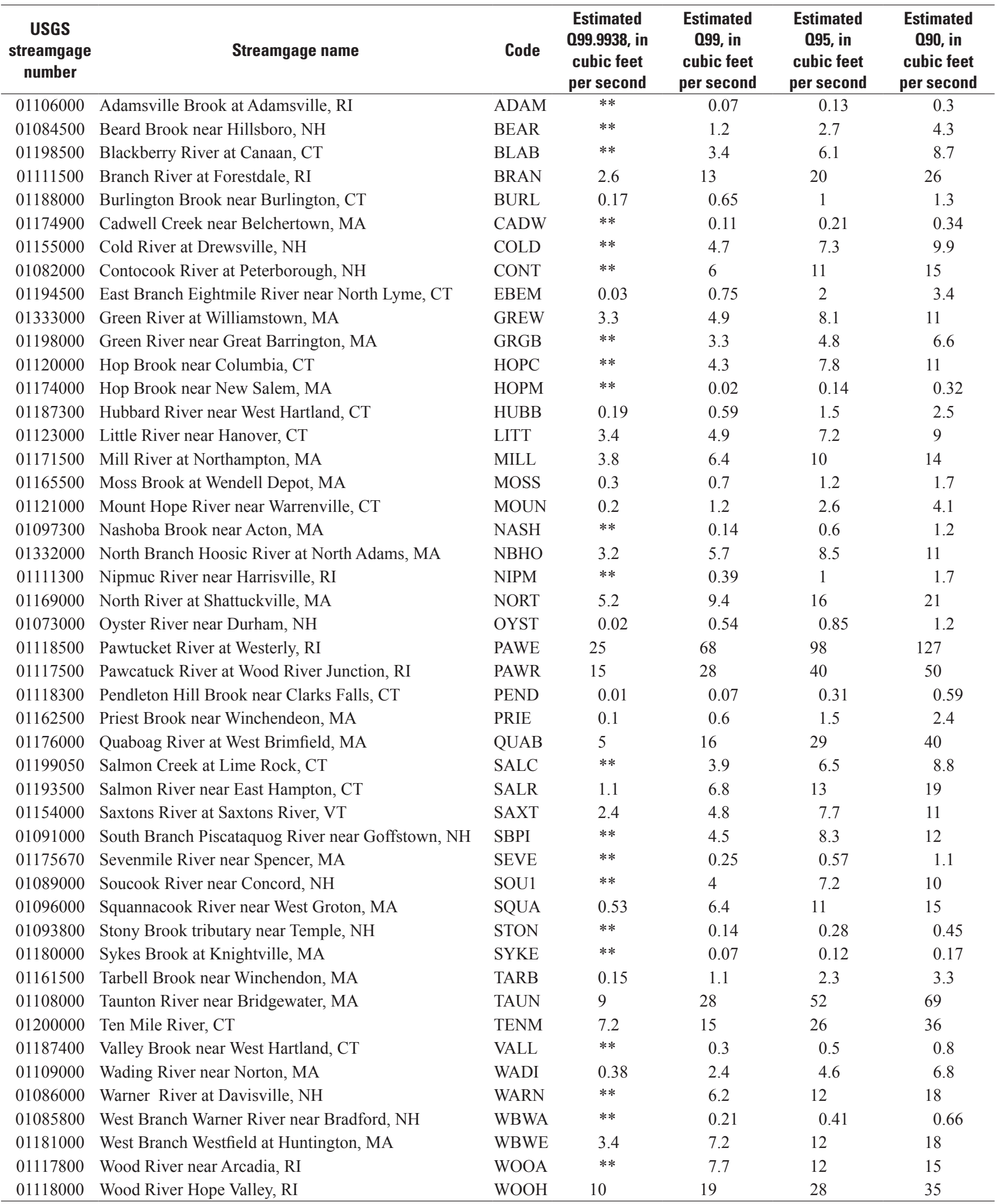


Table 2. Streamflow quantiles corresponding to 17 exceedence probabilities estimated from the observed period of record at 47 U.S. Geological Survey streamgages, New England study area.-Continued

[**, observed streamflow record does not contain enough observations to estimate; QX, streamflow value at the X divided by 100 exceedence probability]

\begin{tabular}{|c|c|c|c|c|c|c|}
\hline $\begin{array}{c}\text { USGS } \\
\text { streamgage } \\
\text { number }\end{array}$ & Streamgage name & Code & $\begin{array}{l}\text { Estimated } \\
085, \text { in } \\
\text { cubic feet } \\
\text { per second }\end{array}$ & $\begin{array}{l}\text { Estimated } \\
080 \text {, in } \\
\text { cubic feet } \\
\text { per second }\end{array}$ & $\begin{array}{l}\text { Estimated } \\
070 \text {, in } \\
\text { cubic feet } \\
\text { per second }\end{array}$ & $\begin{array}{c}\text { Estimated } \\
060 \text {, in } \\
\text { cubic feet } \\
\text { per second }\end{array}$ \\
\hline 01106000 & Adamsville Brook at Adamsville, RI & ADAM & 0.64 & 1.2 & 3.3 & 6.4 \\
\hline 01084500 & Beard Brook near Hillsboro, NH & BEAR & 6.2 & 8.6 & 17 & 27 \\
\hline 01198500 & Blackberry River at Canaan, CT & BLAB & 11 & 14 & 21 & 30 \\
\hline 01111500 & Branch River at Forestdale, RI & BRAN & 32 & 38 & 60 & 87 \\
\hline 01188000 & Burlington Brook near Burlington, CT & BURL & 1.7 & 2 & 2.8 & 3.8 \\
\hline 01174900 & Cadwell Creek near Belchertown, MA & CADW & 0.52 & 0.72 & 1.3 & 2.1 \\
\hline 01155000 & Cold River at Drewsville, NH & COLD & 14 & 17 & 27 & 37 \\
\hline 01082000 & Contocook River at Peterborough, NH & CONT & 19 & 23 & 36 & 50 \\
\hline 01194500 & East Branch Eightmile River near North Lyme, CT & EBEM & 5 & 6.9 & 12 & 20 \\
\hline 01333000 & Green River at Williamstown, MA & GREW & 15 & 19 & 28 & 38 \\
\hline 01198000 & Green River near Great Barrington, MA & GRGB & 9 & 12 & 20 & 32 \\
\hline 01120000 & Hop Brook near Columbia, CT & HOPC & 15 & 21 & 36 & 52 \\
\hline 01174000 & Hop Brook near New Salem, MA & HOPM & 0.58 & 0.81 & 1.6 & 2.5 \\
\hline 01187300 & Hubbard River near West Hartland, CT & HUBB & 3.7 & 5.1 & 9 & 15 \\
\hline 01123000 & Little River near Hanover, CT & LITT & 11 & 13 & 19 & 26 \\
\hline 01171500 & Mill River at Northampton, MA & MILL & 17 & 21 & 30 & 42 \\
\hline 01165500 & Moss Brook at Wendell Depot, MA & MOSS & 2.3 & 3 & 4.8 & 7.4 \\
\hline 01121000 & Mount Hope River near Warrenville, CT & MOUN & 6 & 8.2 & 14 & 22 \\
\hline 01097300 & Nashoba Brook near Acton, MA & NASH & 2 & 3 & 5.1 & 7.7 \\
\hline 01332000 & North Branch Hoosic River at North Adams, MA & NBHO & 14 & 19 & 27 & 37 \\
\hline 01111300 & Nipmuc River near Harrisville, RI & NIPM & 2.6 & 3.8 & 7.4 & 12 \\
\hline 01169000 & North River at Shattuckville, MA & NORT & 27 & 34 & 50 & 70 \\
\hline 01073000 & Oyster River near Durham, NH & OYST & 1.6 & 2.1 & 3.8 & 6.4 \\
\hline 01118500 & Pawtucket River at Westerly, RI & PAWE & 155 & 182 & 248 & 338 \\
\hline 01117500 & Pawcatuck River at Wood River Junction, RI & PAWR & 59 & 70 & 92 & 122 \\
\hline 01118300 & Pendleton Hill Brook near Clarks Falls, CT & PEND & 0.92 & 1.3 & 2.5 & 4 \\
\hline 01162500 & Priest Brook near Winchendeon, MA & PRIE & 3.6 & 5 & 8.4 & 12 \\
\hline 01176000 & Quaboag River at West Brimfield, MA & QUAB & 52 & 64 & 92 & 126 \\
\hline 01199050 & Salmon Creek at Lime Rock, CT & SALC & 11 & 14 & 19 & 25 \\
\hline 01193500 & Salmon River near East Hampton, CT & SALR & 25 & 32 & 55 & 83 \\
\hline 01154000 & Saxtons River at Saxtons River, VT & SAXT & 14 & 18 & 28 & 40 \\
\hline 01091000 & South Branch Piscataquog River near Goffstown, NH & SBPI & 16 & 22 & 36 & 60 \\
\hline 01175670 & Sevenmile River near Spencer, MA & SEVE & 1.8 & 2.6 & 4.3 & 6.6 \\
\hline 01089000 & Soucook River near Concord, NH & SOU1 & 13 & 17 & 28 & 43 \\
\hline 01096000 & Squannacook River near West Groton, MA & SQUA & 18 & 22 & 32 & 47 \\
\hline 01093800 & Stony Brook tributary near Temple, NH & STON & 0.66 & 0.9 & 1.6 & 2.5 \\
\hline 01180000 & Sykes Brook at Knightville, MA & SYKE & 0.23 & 0.3 & 0.6 & 0.91 \\
\hline 01161500 & Tarbell Brook near Winchendon, MA & TARB & 4.5 & 5.7 & 8.7 & 12 \\
\hline 01108000 & Taunton River near Bridgewater, MA & TAUN & 87 & 107 & 170 & 253 \\
\hline 01200000 & Ten Mile River, CT & TENM & 48 & 60 & 95 & 142 \\
\hline 01187400 & Valley Brook near West Hartland, CT & VALL & 1 & 1.6 & 3 & 5 \\
\hline 01109000 & Wading River near Norton, MA & WADI & 9.3 & 12 & 21 & 34 \\
\hline 01086000 & Warner River at Davisville, $\mathrm{NH}$ & WARN & 24 & 32 & 52 & 78 \\
\hline 01085800 & West Branch Warner River near Bradford, NH & WBWA & 0.92 & 1.3 & 2.3 & 3.6 \\
\hline 01181000 & West Branch Westfield at Huntington, MA & WBWE & 24 & 31 & 48 & 72 \\
\hline 01117800 & Wood River near Arcadia, RI & WOOA & 19 & 23 & 32 & 45 \\
\hline 01118000 & Wood River Hope Valley, RI & WOOH & 41 & 49 & 67 & 92 \\
\hline
\end{tabular}


Table 2. Streamflow quantiles corresponding to 17 exceedence probabilities estimated from the observed period of record at 47 U.S. Geological Survey streamgages, New England study area.-Continued

[**, observed streamflow record does not contain enough observations to estimate; QX, streamflow value at the X divided by 100 exceedence probability]

\begin{tabular}{|c|c|c|c|c|c|c|}
\hline $\begin{array}{c}\text { USGS } \\
\text { streamgage } \\
\text { number }\end{array}$ & Streamgage name & Code & $\begin{array}{l}\text { Estimated } \\
050 \text {, in } \\
\text { cubic feet } \\
\text { per second }\end{array}$ & $\begin{array}{l}\text { Estimated } \\
040 \text {, in } \\
\text { cubic feet } \\
\text { per second }\end{array}$ & $\begin{array}{l}\text { Estimated } \\
030 \text {, in } \\
\text { cubic feet } \\
\text { per second }\end{array}$ & $\begin{array}{l}\text { Estimated } \\
020 \text {, in } \\
\text { cubic feet } \\
\text { per second }\end{array}$ \\
\hline 01084500 & Beard Brook near Hillsboro, NH & BEAR & 41 & 58 & 84 & 130 \\
\hline 01198500 & Blackberry River at Canaan, CT & BLAB & 40 & 52 & 71 & 101 \\
\hline 01174900 & Cadwell Creek near Belchertown, MA & CADW & 3 & 4 & 5.2 & 7 \\
\hline 01155000 & Cold River at Drewsville, $\mathrm{NH}$ & COLD & 52 & 71 & 105 & 165 \\
\hline 01082000 & Contocook River at Peterborough, $\mathrm{NH}$ & CONT & 69 & 90 & 120 & 170 \\
\hline 01194500 & East Branch Eightmile River near North Lyme, CT & EBEM & 29 & 39 & 50 & 67 \\
\hline 01333000 & Green River at Williamstown, MA & GREW & 50 & 66 & 87 & 121 \\
\hline 01187300 & Hubbard River near West Hartland, CT & HUBB & 20 & 27 & 37 & 55 \\
\hline 01123000 & Little River near Hanover, CT & LITT & 36 & 47 & 60 & 80 \\
\hline 01171500 & Mill River at Northampton, MA & MILL & 57 & 76 & 100 & 140 \\
\hline 01165500 & Moss Brook at Wendell Depot, MA & MOSS & 10 & 14 & 20 & 30 \\
\hline 01121000 & Mount Hope River near Warrenville, CT & MOUN & 31 & 42 & 56 & 75 \\
\hline 01097300 & Nashoba Brook near Acton, MA & NASH & 11 & 16 & 22 & 31 \\
\hline 01332000 & North Branch Hoosic River at North Adams, MA & NBHO & 48 & 64 & 87 & 125 \\
\hline 01111300 & Nipmuc River near Harrisville, RI & NIPM & 18 & 25 & 34 & 45 \\
\hline 01169000 & North River at Shattuckville, MA & NORT & 94 & 126 & 172 & 249 \\
\hline 01073000 & Oyster River near Durham, NH & OYST & 9.8 & 14 & 19 & 29 \\
\hline 01118500 & Pawtucket River at Westerly, RI & PAWE & 448 & 561 & 703 & 892 \\
\hline 01154000 & Saxtons River at Saxtons River, VT & SAXT & 56 & 76 & 109 & 164 \\
\hline 01091000 & South Branch Piscataquog River near Goffstown, NH & SBPI & 88 & 120 & 163 & 240 \\
\hline 01175670 & Sevenmile River near Spencer, MA & SEVE & 9.2 & 12 & 17 & 23 \\
\hline 01089000 & Soucook River near Concord, NH & SOU1 & 60 & 82 & 112 & 165 \\
\hline 01096000 & Squannacook River near West Groton, MA & SQUA & 66 & 89 & 118 & 162 \\
\hline 01093800 & Stony Brook tributary near Temple, NH & STON & 3.5 & 4.8 & 6.8 & 10 \\
\hline 01180000 & Sykes Brook at Knightville, MA & SYKE & 1.3 & 1.8 & 2.6 & 3.8 \\
\hline 01161500 & Tarbell Brook near Winchendon, MA & TARB & 17 & 22 & 30 & 43 \\
\hline 01108000 & Taunton River near Bridgewater, MA & TAUN & 349 & 455 & 583 & 750 \\
\hline 01200000 & Ten Mile River, CT & TENM & 195 & 260 & 343 & 463 \\
\hline 01187400 & Valley Brook near West Hartland, CT & VALL & 7.2 & 9.6 & 13 & 19 \\
\hline 01109000 & Wading River near Norton, MA & WADI & 50 & 68 & 89 & 117 \\
\hline 01086000 & Warner River at Davisville, $\mathrm{NH}$ & WARN & 119 & 168 & 243 & 364 \\
\hline 01085800 & West Branch Warner River near Bradford, NH & WBWA & 5 & 6.9 & 10 & 15 \\
\hline 01181000 & West Branch Westfield at Huntington, MA & WBWE & 99 & 132 & 178 & 258 \\
\hline 01117800 & Wood River near Arcadia, RI & WOOA & 58 & 74 & 92 & 115 \\
\hline 01118000 & Wood River Hope Valley, RI & WOOH & 119 & 151 & 187 & 233 \\
\hline
\end{tabular}


Table 2. Streamflow quantiles corresponding to 17 exceedence probabilities estimated from the observed period of record at 47 U.S. Geological Survey streamgages, New England study area._- Continued

[**, observed streamflow record does not contain enough observations to estimate; QX, streamflow value at the X divided by 100 exceedence probability]

\begin{tabular}{|c|c|c|c|c|c|c|c|}
\hline $\begin{array}{c}\text { USGS } \\
\text { streamgage } \\
\text { number }\end{array}$ & Streamgage name & Code & $\begin{array}{l}\text { Estimated } \\
015, \text { in } \\
\text { cubic feet } \\
\text { per second }\end{array}$ & $\begin{array}{l}\text { Estimated } \\
010 \text {, in } \\
\text { cubic feet } \\
\text { per second }\end{array}$ & $\begin{array}{c}\text { Estimated } \\
05, \text { in } \\
\text { cubic feet } \\
\text { per second }\end{array}$ & $\begin{array}{c}\text { Estimated } \\
01, \text { in } \\
\text { cubic feet } \\
\text { per second }\end{array}$ & $\begin{array}{c}\text { Estimated } \\
0006 \text {, in } \\
\text { cubic feet } \\
\text { per second }\end{array}$ \\
\hline 01106000 & Adamsville Brook at Adamsville, RI & ADAM & 26 & 34 & 47 & 95 & $* *$ \\
\hline 01084500 & Beard Brook near Hillsboro, NH & BEAR & 170 & 230 & 364 & 777 & $* *$ \\
\hline 01198500 & Blackberry River at Canaan, CT & BLAB & 122 & 160 & 240 & 556 & $* *$ \\
\hline 01111500 & Branch River at Forestdale, RI & BRAN & 304 & 377 & 514 & 951 & 3,870 \\
\hline 01188000 & Burlington Brook near Burlington, CT & BURL & 13 & 17 & 26 & 61 & 477 \\
\hline 01174900 & Cadwell Creek near Belchertown, MA & CADW & 8.6 & 11 & 17 & 40 & $* *$ \\
\hline 01155000 & Cold River at Drewsville, $\mathrm{NH}$ & COLD & 215 & 293 & 447 & 933 & $* *$ \\
\hline 01082000 & Contocook River at Peterborough, $\mathrm{NH}$ & CONT & 210 & 272 & 393 & 730 & $* *$ \\
\hline 01194500 & East Branch Eightmile River near North Lyme, CT & EBEM & 81 & 101 & 139 & 287 & 1,490 \\
\hline 01333000 & Green River at Williamstown, MA & GREW & 146 & 187 & 271 & 525 & 2,100 \\
\hline 01198000 & Green River near Great Barrington, MA & GRGB & 150 & 195 & 281 & 566 & $* *$ \\
\hline 01120000 & Hop Brook near Columbia, CT & HOPC & 223 & 283 & 400 & 785 & $* *$ \\
\hline 01174000 & Hop Brook near New Salem, MA & HOPM & 11 & 14 & 20 & 42 & $* *$ \\
\hline 01187300 & Hubbard River near West Hartland, CT & HUBB & 70 & 94 & 148 & 350 & 1,310 \\
\hline 01123000 & Little River near Hanover, CT & LITT & 93 & 115 & 167 & 360 & 1,870 \\
\hline 01171500 & Mill River at Northampton, MA & MILL & 172 & 219 & 319 & 674 & 3,440 \\
\hline 01165500 & Moss Brook at Wendell Depot, MA & MOSS & 37 & 48 & 69 & 140 & 786 \\
\hline 01121000 & Mount Hope River near Warrenville, CT & MOUN & 90 & 113 & 165 & 355 & 2,250 \\
\hline 01097300 & Nashoba Brook near Acton, MA & NASH & 38 & 49 & 66 & 121 & $* *$ \\
\hline 01332000 & North Branch Hoosic River at North Adams, MA & NBHO & 160 & 220 & 348 & 753 & 4,080 \\
\hline 01111300 & Nipmuc River near Harrisville, RI & NIPM & 53 & 67 & 98 & 200 & $* *$ \\
\hline 01169000 & North River at Shattuckville, MA & NORT & 318 & 428 & 672 & 1,460 & 7,580 \\
\hline 01073000 & Oyster River near Durham, NH & OYST & 36 & 47 & 70 & 138 & 681 \\
\hline 01118500 & Pawtucket River at Westerly, RI & PAWE & 1,020 & 1,200 & 1,490 & 2,180 & 5,940 \\
\hline 01117500 & Pawcatuck River at Wood River Junction, RI & PAWR & 340 & 395 & 487 & 702 & 1,780 \\
\hline 01118300 & Pendleton Hill Brook near Clarks Falls, CT & PEND & 15 & 19 & 26 & 50 & 251 \\
\hline 01162500 & Priest Brook near Winchendeon, MA & PRIE & 62 & 81 & 119 & 225 & 1,240 \\
\hline 01176000 & Quaboag River at West Brimfield, MA & QUAB & 458 & 551 & 713 & 1,130 & 7,540 \\
\hline 01199050 & Salmon Creek at Lime Rock, CT & SALC & 83 & 101 & 141 & 280 & $* *$ \\
\hline 01193500 & Salmon River near East Hampton, CT & SALR & 324 & 402 & 568 & 1,150 & 8,230 \\
\hline 01154000 & Saxtons River at Saxtons River, VT & SAXT & 215 & 290 & 450 & 954.6 & 3,340 \\
\hline 01091000 & South Branch Piscataquog River near Goffstown, NH & SBPI & 305 & 403 & 600 & 1,150 & $* *$ \\
\hline 01175670 & Sevenmile River near Spencer, MA & SEVE & 27 & 34 & 48 & 87 & $* *$ \\
\hline 01089000 & Soucook River near Concord, NH & SOU1 & 207 & 275 & 405 & 765 & $* *$ \\
\hline 01096000 & Squannacook River near West Groton, MA & SQUA & 199 & 252 & 365 & 700 & 3,330 \\
\hline 01093800 & Stony Brook tributary near Temple, $\mathrm{NH}$ & STON & 13 & 17 & 26 & 57 & $* *$ \\
\hline 01180000 & Sykes Brook at Knightville, MA & SYKE & 4.7 & 6.2 & 9.3 & 19 & $* *$ \\
\hline 01161500 & Tarbell Brook near Winchendon, MA & TARB & 54 & 70 & 103 & 185 & 1,390 \\
\hline 01108000 & Taunton River near Bridgewater, MA & TAUN & 880 & 1,060 & 1,390 & 2,200 & 4,700 \\
\hline 01200000 & Ten Mile River, CT & TENM & 550 & 681 & 941 & 1,800 & 10,200 \\
\hline 01187400 & Valley Brook near West Hartland, CT & VALL & 24 & 30 & 51 & 109 & $* *$ \\
\hline 01109000 & Wading River near Norton, MA & WADI & 137 & 168 & 223 & 360 & 1140 \\
\hline 01086000 & Warner River at Davisville, $\mathrm{NH}$ & WARN & 457 & 590 & 866 & 1,620 & $* *$ \\
\hline 01085800 & West Branch Warner River near Bradford, NH & WBWA & 20 & 27 & 47 & 109 & $* *$ \\
\hline 01181000 & West Branch Westfield at Huntington, MA & WBWE & 328 & 440 & 675 & 1,530 & 9,800 \\
\hline 01117800 & Wood River near Arcadia, RI & WOOA & 131 & 155 & 197 & 319 & $* *$ \\
\hline 01118000 & Wood River Hope Valley, RI & WOOH & 265 & 314 & 401 & 650 & 2,040 \\
\hline
\end{tabular}



Prepared by the Pembroke Publishing Service Center. For more information concerning this report, contact:

Director U.S. Geological Survey Massachusetts-Rhode Island Water Science Center 10 Bearfoot Road Northborough, MA 01532 dc_ma@usgs.gov or visit our Web site at: http://ma.water.usgs.gov 
ISBN 1-41]3-2664-4 